\title{
POLLEN MORPHOLOGY OF THE ALANGIACEAE
}

\section{TJ. REITSMA}

Division of Palaeobotany and Pollen Morphology, Botanical Museum and Herbarium, State University, Utrecht (The Netherlands)

(Received July 24, 1970)

\section{SUMMARY}

This paper presents a pollen-morphological study of Alangium, a genus mainly restricted to the tropics of the Old World, of which 18 of the 19 known species were studied. The pollen grains, studied with the use of a light microscope, a transmission electron microscope and a scanning electron microscope, were classified into 15 pollen types, to which a key is given. Comparison of fossil and recent grains produced some information about both the evolutionary trends in the characters of the pollen grains and the phytogeography of Alangium.

\section{INTRODUCTION}

Alangium, the only member of the Alangiaceae, occurs in Africa, India, China, Japan, Malaysia and in some Pacific islands. It is a genus of trees, or sometimes shrubs or woody climbers, which occur from sea level to $3,300 \mathrm{~m}$ above sea level. The importance of Alangium lies in the fact that this genus is found in Tertiary sediments, mostly outside the present area (e.g., Traverse, 1955; KrutzsCH, 1962, 1969). Because no agreement exists about the relationship of the fossil pollen grains to the recent ones, it seemed useful to make a comprehensive study of the recent pollen grains, the more so as a comparison of fossil and recent pollen grains can provide some information about the evolution of the characters. For this reason it was necessary to study pollen grains of various specimens collected in different areas in order to obtain a survey of the variability of the features in recent pollen grains.

Since the identification of the specimens used is not always correct, it is necessary that pollen-morphological studies should be done in cooperation with an expert in taxonomy, or with the help of a recent monograph. Otherwise pollenmorphological studies lose their value, as the results are not always reliable. Fortunately BLOEMBERGEN (1939) presented an excellent monograph of the Alangiaceae. It is clear that the present study could not have been undertaken without this monograph at hand. 


\section{Light microscopy}

Pollen grains of Alangium were obtained from herbarium material, from which the anthers had just opened. These anthers were isolated with the use of wetting agent. Afterwards the anthers were ground through a sieve and acetolysed (for detailed description see REITSMA, 1969). The acetolysed pollen grains were mounted in glycerin jelly. Granules of modelling clay were used in order to prevent large pollen grains from being compressed.

Pollen grains were examined with a Leitz Ortholux microscope (obj. pl. apo öl 100/1.32,oc. periplan GF $10 \times$ ). Photomicrographs were made with the use of a Leitz Orthomat and a Leitz Ortholux microscope (obj. apo 40/0.65 and Fl öl 70/1.30).

\section{Transmission electron microscopy}

Acetolysed pollen grains were concentrated into pellets by agar embedding (RowLEY, 1959). These pellets were cut into small cubes by means of a razor blade. The agar-exine cubes were dehydrated and then embedded in Epon 812 . Thin sections were cut with a LKB-microtome and examined with the use of a Philips EM-100 electron microscope.

The electron-microscopical investigations were carried out in the Department of Electron Microscopy of the Catholic University at Nijmegen (head: Dr. M. M. A. Sassen).

\section{Scanning electron microscopy}

Pollen grains were rinsed in $100 \%$ alcohol immediately after treatment in acetolysis mixture. The pollen grains, stored in $100 \%$ alcohol, were fixed to specimen holders and then coated under high vacuum with a very thin film of coal and gold (100 $\AA \mathrm{C}, 500 \AA \mathrm{Au})$. The pollen grains were studied with a Cambridge Stereoscan MK IIa scanning electron microscope.

The scanning-electron-microscopical investigations were carried out in the Institute of Medical Physics of the University of Munster, Germany.

\section{MATERIAL}

Herbarium material from the following herbaria was used in this study. BO Bogor (Indonesia): Herbarium Bogoriense, Lembaga Biologi Nasional. BR Bruxelles (Belgium): Jardin Botanique de l'Etat.

K Kew (Great Britain): Royal Botanic Garden, The Herbarium and Library. 
L Leiden (The Netherlands): Rijksherbarium.

NY New York (N.Y., U.S.A.): The New York Botanical Garden.

P Paris (France): Muséum National d'Histoire Naturelle, Laboratoire de Phanérogamie.

S Stockholm (Sweden): Naturhistoriska Riksmuseet, Botanical Department.

U Utrecht (The Netherlands): Botanical Museum and Herbarium.

WAG Wageningen (The Netherlands): Laboratory of Plant Taxonomy and Plant Geography.

The author is indebted to the directors, keepers and curators of the above mentioned herbaria for the loan of herbarium specimens.

As a rule the use of pollen from type-material has been avoided, except in the case of $A$. brachyanthum, as only a single specimen is known from this species. As far as possible all known species of the genus Alangium were examined. BLOEMBERGEN (1939) listed eighteen species of Alangium in his excellent monograph of the genus. Three further species have been described since Bloembergen's monograph appeared. According to EYDE (1968) two of these, A. chungii $\mathrm{LI}$ and $A$. tonkinense GaGnePaIN, are conspecific with $A$. salviifolium and $A$. kurzii, respectively. The third species, $A$. griseolloides CAPURON, appears to be a good species. Therefore, the genus Alangium includes 19 species, of which 18 have been studied. It was not possible to study pollen grains of $A$. hirsutum BLOEMBERGEN, because the single specimen known from this species was not present at the Rijksherbarium of Leiden (The Netherlands), although BloEmBERGEN (1939) cites a Bornean specimen, Hallier B.3238, from the Rijksherbarium.

BLOEMBERGEN (1939) classified the species into four sections. According to Capuron (1962) A. griseolloides, the only species not mentioned by Bloembergen, belongs to section Conostigma. I have followed Bloembergen's delimitation of the taxa and I have also adhered to his nomenclature and orthography, with a few exceptions, in order to bring them into harmony with the INTERNATIONAL Code of Botanical Nomenclature (1966). According to Article 22 of this Code, section Angolum BallLoN, which includes the type species of Alangium, must be renamed section Alangium. According to Article 26 the names of the following subspecies must be altered, because the subspecies includes the nomenclatural type of the species: A. salviifolium (L.) WANGERIN ssp. decapetalum (LAMARCK) WANGERIN must be changed into $A$. salviifolium (L.) WANGERIN ssp. salviifolium; A. villosum (Blume) Wangerin ssp. salaccense (KoORders et Valeton) BloemBERGEN has to be changed into $A$. villosum (BLUME) WANGERIN ssp. villosum. The same article is also relevant to $A$. villosum (BLUME) WANGERIN ssp. tomentosum (Von Mueller) Bloembergen var. australe Bloembergen. This name has to be altered into $A$. villosum (BLUME) WANGerin ssp. tomentosum (VON MUELLER) BLOEMBERGEN var. tomentosum. According to Recommendation $73 \mathrm{G}$ the specific epithet salvifolium is spelled salviifolium. 


\section{SPECIMENS EXAMINED}

\section{Alangium LAMARCK}

\section{Section Alangium}

A. brachyanthum MerRILL-Luzon: Forestry Bureau 10341 Curran (NY, isotype).

A. longiflorum MerRILL-Luzon: Alberto 326 (U), Forestry Bureau 14773 Darling (BO, isotype); northern Borneo: Aban Gibot SAN 30390 (L); Moluccas: Main and Aden 1465 (L, BO).

A. salviifolium (L) W ANGERIN ssp. salviifolium-Kenya: Kenya Forestry Department Dale 3763 (K); Tanzania: Semsei 977 (K); India, Malabar: Stocks, Law s.n. (NY); southern India: Ekambaran and Janaki s.n. (NY), Wight 1062 (NY). Wight 1063 (NY), Wight 1256 (L), Yeshoda 332 (NY); Hainan: Hancock 35 (K), Liang 65366 (NY), How 70323 (K), How 71319 (S); North Vietnam: Pételot 6386 (NY); Thailand: Garrett 1075 (L), Royal Forest Department 88 (NY); South Vietnam: Pierre 5157 (NY), Pierre 9179 (NY).

A. salviifolium (L) WANGerin ssp. sundanum (MiQuel) Bloembergen-India, Malabar Coast: s.c. s.n. coll. 20-5-20 (S), Wight 1064 (NY), Wight 1255 (L); India, Mysore: Hohenacker 700 (U); Ceylon: s.c. s.n. (P), Walker s.n. (P), Walker 38 (K), Wight 1254 (K); Andaman Islands: Parkinson 540 (K); Sumatra: Achmad 399 (L); Java: Bogor Botanic Garden XVII-C-136 (L), s.c. s.n. 043707 H.B. (U), Zollinger 2289 (L); Sumba: Teysman s.n. (L); Celebes: Teysman 13832 (L); New Guinea: Pleyte 1034 (L), Zippelius 197c (L).

\section{Section Conostigma Bloembergen}

A. griseolloides CAPURON-Madagascar: Service Forestier de Madagascar 25752 S.F. (P).

A. havilandii Bloembergen-Borneo, Sarawak: Anderson 12868 (L, BO), Sanusi bin Tahir 9218 (L).

A. javanicum (BLUME) WANGERIN-Malaya: Griffith 3383 (U), Henderson 28980 (BO), King's coll. s.n. (L), Maingay 706 (L); Sumatra: Achmad 1266 (L); Bangka: Kostermans and Anta 1152 (L); Java: Blume 7529 (L); Borneo, Sabah: Ampuria 36521 (L), Elmer 21165 (L, S), Kostermans 4365 (L), Mikil 41761 (L), Muin Chai SAN 26904 (L), Wood SAN 15084 (L), Wood and Charington 15400 (L); Borneo, Sarawak: Havilland and Hose 2885 (L), Jacobs 5359 (L); Nunukan Island: Paymans 180 (L); Brunei: Smythies and Ashton 5851 (L); Celebes: Boschpr. b.b. Cel/V/199 (L, BO); Philippine Islands, Luzon: Elmer 14782 (S, U), Forestry Bureau 2284 Meyer (S, U); Mindoro: Edano 3245 (L); Moluccas, Seram: Kuswata and Soepadmo 78 (L), Rutten 1832 (BO); New Guinea: Ledermann 9818 (L), Schram 9455 (L); Solomon Islands: Brass 3002 (L), Snijder 4461 (L), Van Royen 16421 (L), Walker and White 167 (L), Whitmore 768 (L), Whitmore 942 (L).

\section{A. maliliense BLOEMBERGEN-Celebes: Cel/V/161 (Waturandang 43) (BO, L).}

A. nobile (ClarKe) Harms-Malaya: Griffith 3885 (U), King's coll. 6116 (BO), King's coll. 10892 (L); Sumatra: Bequin 582 (L), Boschpr. T.3.P.864 (L).

A. ridleyi KING-Malaya: Kochumen KF 99369 (L); Sumatra; Achmad 1297 (U), Boschpr. 131.T.3.P.369 (L), Boschpr. 160 E.1.P.852 Thorenaar (L); Borneo: Kostermans 10178 (BO), Sauveur 141 (L).

\section{Section Marlea BaILlon}




\section{A. alpinum SMITH et CAVE-Sikkim: Hooker s.n. (K).}

A. barbatum (Clarke) Harms-China, Kwangtung: Sin 9570 (NY); China, Kwangsi: Morse 709 (K); China, Hainan: Woon Young Chun 6957 (NY); Thailand: Garrett 1317 (L), Garrett 1451 (L); South Vietnam: Clemens 4200 (NY), Pételot 4822 (NY).

A. chinense (Loureiro) Harms-Africa, Cameroun: Breteler 1376 (BR), Breteler 2884 (WAG), Deistel 579 (S), Zenker 1416 (L); East Congo: Donis 3943 (BR), Lebrun 4936 (BR), Pierlot 329 (BR), Pierlot 3055 (K), Troupin 10231 (BR); Uganda: Sangster 479 (K); Tanzania: Bruce 453 (K), Greenway 3309 (K), Verdcourt 1716 (BR); India, Punjab: Koeltz 4579 (NY), Koeltz 4771 (NY); Siwalik: Atal Sing Dewan 65 (NY), d'Alleizette 2971 (L), Mohan Lal Punj 62 (NY); Kumaon: Bis Ram 2189 (NY); Bengal: Culta in Hort. Calcuttensis s.n. (L); Nepal: Wallich 3719 (NY); Sikkim: Prain's coll, s.n. (L); Assam: Jenkins s.n. (L); Burma: Rock 10228 (NY); China, Szechwan: Rock 16125 (NY), Rock 24562 (NY); Hupeh: Chow 574 (NY), Wilson 501 (NY), Wilson 1134 (NY), Wilson 2757 (NY); Nanching: Merrill and Swingle 11359 (NY); Kweichow: Tsiang 5275 (NY), Tsiang 5343 (NY); Kwangtung: Tso 21110 (NY); Kwangsi: Ching 5486 (NY), Steward and Cheo 706 (NY); Yunnan: d'Alleizette s.n. (L), Henry 10142 (NY), Henry 10647 (NY), Rock 8873 (NY); North Vietnam: Pételot 4736 (NY); Laos: Thorel s.n. (NY); Thailand: Bloembergen 509 (BO, L), Kerr 1121 (L); Cambodia: Pierre 573 (NY); Philippine Islands, Luzon: Edano 17791 (L), Ramos 978 (NY); Mindoro: Conklin 17542 (L); Negros: Elmer 10311 (NY); Mindanao: For. Bur. 29767 Cenabre (NY), Bur. Sci. 49289 Ramos and Edano (BO); Flores: De Jong 38 (BO); Sumba: de Voogd 2241 (BO); Sumbawa: Colfs 180 (L), Kostermans 18099 (L); Java: Boschpr. Ja 4349 (BO), Koorders $1303 \beta$ (BO), Zollinger II $2292(\mathrm{~L})$.

A. griffithii (Clarke) HaRms-Malaya: King's coll. 5824 (K), Kochumen KF 99331 (L), Lambak 2720 (K), Scortechini 1914 (U); Sumatra: Iboet 39 (BO), Rahmat si Toroes 5549 (S); Java: Koorders 28895 $\beta$ (BO); Sabah: Ambullah 33383 (L), Muin Chai SAN 29848 (L); Borneo: Amdjah 807 (BO); Celebes: Boschpr. Cel./V-128 (BO); Moluccas, Halmahera: Bequin 1977 (BO).

A. kurzii CralB-Burma: Manson 98 (K), Parkinson 2029 (K); China, Hupeh: Wilson 2232 (NY); Anhwei: Fan and Li 190 (L); Chekiang: Ching 1793 (S); Fukien: Chung 3442 (BO); Kiangsi: Chung and Sun 203 (NY); Hunan: Dahlström 10 (S); Kwangtung: Tsang 20555 (NY), Tsiang 2064 (NY), Tsui 224 (NY); Hainan: Lau 1562 (NY), Lei 513 (L, NY), Liang 61667 (NY), McClure 9358 (NY); Kwangsi: Tsang 22181 (S); Hongkong: Wright s.n. (NY); Thailand: van Beusekom 300 (L), Kerr 17893 (L); South Vietnam: d'Alleizette s.n. (L); Malaya: Kochumen KF 19037 (L); Sumatra: Boschpr. b.b. 9730 (L), Culta in Hort. Sibolangit 80 (NY), Philips 99 (BO), Theunissen 8 (L), Yates 2485 (NY); Java: Blume s.n. (L, U).

A. platanifolium (SIebold et ZuCCARINI) HaRms-China, Hupeh: Henry 5813 (K), Wilson 3272 (K); Korea: s.c. 3484 (S), Wilson 10384 (K); Cheju Do: Oldham 471 (L); Japan, Hokkaido: Akiyama s.n. (L); Honshu: Hashimoto 1533 (NY), Kitamura and Murata 2248 (U), Maries s.n. (K), Masao Azuma s.n. (U), Maximowicz Iter sec. s.n. (K), Murata 8849 (U), Murata and Shimizu 1854, Togashi 7322 (S); Kyushu: d'Alleizette 2970 (L).

A. rotundifolium (HASSKARL) BLOEMBERGEN-Sumatra: Boschpr. b.b. 6818 (Buys 32) (BO); Java: Ja 4729 (BO), Junghuhn s.n. (L), Winckel $78 \beta$ (L); Sabah: Clemens 29650 (L). 23361 (BO).

A. scandens BloEMBergen-Sumatra: Ajoeb 370 (BO, L); Sarawak: Murthy and Ashton

\section{Section Rhytidandra BAILLON}

A. villosum (Blume) Wangerin ssp. bussyanum (Baillon) Bloembergen-New Caledonia: McKee 5151 (L). 
A. villosum (Blume) WANGerin ssp. ferrugineum (WhIte) Blokmbergen-New Guinea: Brass 1066 (L), Brass 22698 (L).

A. villosum (BLUme) Wangerin ssp. parviflorum Bloembergen-Lombok: de Voogd 2704 (BO); Timor: Bloembergen 3469 (BO, L).

A. villosum (Blume) WANGerin ssp. pilosum (Merrill) Bloembergen-Philippine Islands, Luzon: Bur. Sci. 32715 Ramos (L).

A. villosum (BLUme) WANGerin ssp. polyosmoides (VoN MUeller) BloembergenAustralia, Queensland: Beckler s.n. (K), Brass 20308 (K, L), Clemens s.n. (K); New Guinea: Carr 14684 (L), Hoogland 9183 (L), Van Royen and Sleumer 8126 (L).

A. villosum (BLUME) WANGERIN ssp. solomonense BLOEMBERGEN-Solomon Islands: Whitmore $777(\mathrm{~L})$.

A. villosum (Blume) Wangerin ssp. tomentosum (Von Mueller) Bloembergen var. javanum BLOEMBERGEN-Java: Koorders $14640 \beta$ (L).

A. villosum (BLUme) WANGerin ssp. tomentosum (Von MUeller) Bloembergen var. tomentosum-Australia, Queensland: Tryon s.n. (BO).

A. villosum (BLUME) WANGERIN ssp. villosum-Java: Blume s.n. (L, U).

A. villosum (Blume) Wangerin ssp. vitiense (GRAY) Bloembergen-Fiji: Degener 15500 (S, NY), Smith 845 (BO), Smith 1002 (NY), Smith 1475 (NY), Smith 8186 (S).

A. villosum (BLUME) WANGerin ssp. warburgianum (WANGerin) BlOEMBERGEN-Moluccas, Batjan: Boschpr. b.b. 23243 (de Haan 142 )(BO).

\section{TERMINOLOGY}

The terminology used in this study is in accordance with that described by the present author (REITSMA, 1970).

\section{PREVIOUS STUDIES ON POLLEN MORPHOLOGY}

ERdTMAN (1948) mentions Alangium as an example of a genus which is well-defined on one hand but which is on the other hand not homogeneous with regard to its pollen morphology. Some species have distinctly colporate pollen grains, while others have orate (pororate) pollen grains.

ERDTMAN (1952) presents a brief character of the pollen grains of the Alangiaceae. He distinguishes two main groups. One group has a more or less smooth contour line and a sexine which is about as thick as the nexine; the other group has no smooth contour line and a sexine which is considerably thicker than the nexine. The species $A$. chinense and $A$. nobile belong to the first group. The second group can be divided into two subgroups, of which one is characterized by a striate or broadly striate-rugulate pattern (A. kurzii and A. platanifolium); the other one is characterized by warts, supported by small columellae ( $A$. long $i$ - 
florum, A. salviifolium, $A$. villosum). He mentions that there is a slight similarity between the pollen grains of $A$. chinense and those of Nyssa chinense, although the position of the Alangiaceae is still controversial.

Chao (1954) studies the pollen grains of Cornaceae and their allies. He describes pollen grains of Alangium handelii SchifF., A. chinense ReHD., A. platanifolium HARMS and $A$. premnifolium OHWI. All the pollen grains are tricolporate, reticulate and oblate. He states that the pollen grains are tricolpate, but it appears from his drawings that he means colporate in stead of colpate. Apparently he did not consult Bloembergen's monograph of Alangium, for his identifications are not correct. $A$. handelii ScHIFF. is not an existing name; he probably means $A$. handelii SCHNARF and this is according to Bloembergen a synonym of $A$. kurzii Craib. A. premnifolium is synonymous with $A$. chinense (Loureiro) HaRms or with $A$. kurzii CralB. The determination of the specimen Lau 24240 as $A$. platanifolium Harms is probably incorrect, it should be identified as $A$. kurzii Craib or $A$. chinense (Loureiro) Harms. Chao studied, consequently, one or two species of the section Marlea.

YeRAMYAN $(1967,1968)$ separates the pollen grains of Alangium into two types, viz., the Marlea type and the Alangium type. The Marlea type is subdivided into two subtypes, viz., Alangium ridleyi subtype and $A$. vitiense subtype. The species $A$. begoniifolium (RoxB.) BaILLON, A. ebenaceum GrIfFITH, A. griffithii Harms, $A$. javanicum (Koorders et Valeton) Wangerin, $A$. meyeri Merrill, $A$. macrophyllum Siebold et ZucCarini, $A$. nobile (Clarke) Harms, A. platanifolium (Siebold et ZuccarinI) Harms and $A$. ridleyi King belong to the $A$. ridleyi subtype. The species $A$. faberi OLIVER and $A$. vitiense (Gray) BaIllon belong to the $A$. vitiense subtype. The species $A$. salviifolium (L.) WANGERIN and $A$. lamarckii ThwaItes belong to the Alangium type.

The diagnoses of the types and subtypes are too short, and the differential characteristics are indistinct. In fact, she uses overlapping features.

It is a pity that Mrs. Yeramyan was not familiar with the last monograph of this family, for many of her species names are synonymous according to Bloembergen. If we use the species concept of Bloembergen, then her results are as follows: The species $A$. chinense, $A$. kurzii, A. rotundifolium, A. javanicum, $A$. griffithii, $A$. platanifolium, $A$. nobile and $A$. ridleyi belong to her $A$. ridleyi subtype. $A$. barbatum and $A$. villosum ssp. vitiense belong to the $A$. vitiense subtype, and $A$. salviifolium to the Alangium type. In other words the sections Conostigma, Marlea and Rhytidandra belong to her first type and the section Alangium to the second one. Therefore, her results are in favour of a reinstatement of the genus Marlea RoxB.

Since Mrs. Yeramyan did not cite herbarium vouchers for her pollen preparations, it is impossible to check her results.

STraka and Simon (1967) describe and show pictures of pollen grains of $A$. 
griseolloides and A. salviifolium. Since this study appeared as a part of the Pollen Flora of Madagascar and the Mascarenes, the results have not been discussed.

EYDE et al. (1969) present the most complete pollen-morphological study of Alangiaceae so far published, in which the greater part of the species is described and depicted. Their conclusion is as follows: "in view of the great variation found in different collections of the same species and the overlapping characters found in the four sections, it is apparent that the pollen grains of Alangium cannot be sharply separated into types and subtypes that correspond to the groupings based on other taxonomical characters"'. The present author cannot confirm this statement.

\section{GENERAL MORPHOLOGY}

\section{Apertures}

The pollen grains of Alangium are basically 3-aperturate. In the sections Marlea and Conostigma exceptionally 2- and 4-aperturate pollen grains occur. In the section Rhytidandra the number of apertures varies from 3 to 6 and in the section Alangium from 3 to 8 . The pollen grains are all zonoaperturate. In some grains in the section Alangium one or two apertures can be situated outside the equatorial zone. The apertures are always compound. In some pollen grains in the section Alangium simple ecto- or endoapertures are present together with compound apertures.

\section{Ectoapertures}

Mostly the ectoapertures are colpi. However, in the section Alangium and in the African specimens of $A$. chinense ectopori can be found. The length and width of the colpi vary in each type. The ectoapertures have either tapering or rounded ends. The aperture membrane is sometimes nudate, and sometimes beset with a large number of small granules or with some large granules. The ectoapertures are mostly surrounded by a closed sexine zone. Sometimes the closed sexine is only present in the region of the endoaperture, while the remaining part of the ectoaperture is bounded by the sexine elements of the structure pattern. In some types of the sections Marlea and Conostigma the closed sexine can be thickened. This thickening is present in the region of the endoaperture at least. The length of this thickened or unthickened closed sexine part varies from the same length as the colpi to very short. In the section Rhytidandra and partly in the section Alangium the ectoapertures are bounded by detached sexine elements. In the sections Marlea and Conostigma the ectoapertures can be accompanied by thickenings of the nexine. 


\section{Endoapertures}

The endoapertures are generally larger than the maximum width of the ectoapertures. Small endoapertures occur in the section Rhytidandra. The outline of the endoapertures varies strongly. Even the pollen grains from one flower can have a lalongate colpus, a lalongate porus, a circular porus or a lolongate porus. This outline has, consequently, no diagnostic value. In all types the endoaperture is distinctly delimited. The endoapertures can be bordered either by a scarcely thickened zone of the nexine or by a distinctly thickened zone, at least $1.7 \times$ thicker than the remaining nexine. These thickened zones can be either narrow or broad. In some types within the sections Conostigma and Marlea the endoaperture and the accompanying costae are bordered by a thinning of the nexine. The width of this thinning varies from narrow to broad.

\section{Ornamentation}

The ornamentation of the pollen grains shows a considerable variation, which can be of great diagnostic value. Two types of ornamentation are present. One type is a structure pattern consisting of lumina and muri, while the other pattern consists of more or less detached elements which give the pollen grains a warty appearance. To the first type belong reticulate, rugulate and striate patterns. This type is found in the sections Conostigma and Marlea, except in the African specimens of $A$. chinense. The size and the shape of the lumina vary greatly. In some types of the section Marlea ( $A$. platanifolium type, and partially in the $A$. kurzii type), two different patterns can be detected in two levels of the sexine. The uppermost pattern is a striate or rugulate one, built up of large fused capita, while the innermost pattern is a reticulate one, built up of small fused capita. Sometimes the innermost pattern is independent of the uppermost pattern, i.e., they have no elements in common. It is also possible that the large elements of the outermost pattern are connected with the capita, which form the innermost pattern.

The second type is found in the sections Alangium, Rhytidandra and in the African specimens of $A$. chinense. EYDE et al. (1969) describe the processes as verrucae. On closer examination such a process appears to consist of a hemispherical, verruca- or gemma-like sexine part, subtended by thin and short columellae. In other words the warty processes are nothing but fused capita of different shape and size. For these kinds of processes the terms verrucae or gemmae cannot be used. Sometimes small processes are found between the large ones. These processes, also build up of columellae and capita, can be either detached or arranged into a reticulate pattern. 
The thickness of the exine varies from $2 \mu$ to $9 \mu$. The nexine varies in thickness, and is sometimes thicker than the sexine (section Conostigma, and some types of the section Marlea) and sometimes thinner than the sexine (sections Alangium and Rhytidandra and some types of the section Marlea). It also occurs that the sexine and the nexine are about the same thickness. The thickness of the exine must be measured in the middle of the mesocolpium or mesoporium. The sexine always consists of columellae and capita. Mostly the capita are fused. The columellae are always short or very short. The thickness of the columellae varies from thick to thin. The capita may be elongate longitudinally, rounded or elongate transversely. Sometimes capita of different sizes can be found in one pollen grain ( $A$. platanifolium type, $A$. villosum type and partially in the $A$. kurzii type and in the $A$. salviifolium type).

\section{Shape}

In equatorial view the outline is always elliptic, while in polar view it is basically angular. The number of angles corresponds to the number of apertures. The sides are either convex or straight. The apertures are situated in the angles, which are always obtuse. Sometimes the outline is circular.

Size

The polar axis is always shorter than the equatorial diameter, so and therefore the longest axis represents the latter. The longest axis varies from $45 \mu$ to $110 \mu$. The $\mathrm{P} / \mathrm{E}$ ratio varies from transverse to subtransverse.

\section{KEY TO THE POLLEN TYPES}

1. a. Pollen grain provided with more or less detached elements, rounded or angular . . 2

b. Pollen grain provided with a structure pattern build up of lumina and muri . . . . 5

2. a. Ectocolpus distinct; sunken . . . . . . . . . . . A. villosum type

b. Ectocolpus distinct or indistinct; not sunken . . . . . . . . . . . . . . 3

3. a. Costae of the endoaperture heavy, passing into costae ectocolpi $A$. javanicum type

b. Costae of the endoaperture faint, costae ectocolpi not present . . . . . . . . 4

4. a. Ectoaperture surrounded by a closed and distinctly thickened part of the sexine, or sometimes bordered by a closed and distinctly thickened part of the sexine in the region of the endoaperture, varying in length; pollen grains always 3-zonocolporate ... . . . . . . . . . . . . A. chinense type C

b. Ectoaperture bordered by sexine elements not differing from the rest of the sexine, or sometimes bordered by a closed but unthickened part of the sexine in the region of the endoaperture; pollen grains mostly 4-8 aperturate, rarely 3-zonoaperturate

5. a. Pollen grain provided with two distinct structure patterns, different from each other and situated in two different levels of the sexine. . . . . . . . . . . 6 
b. Pollen grain provided with a single structure pattern.

6. a. Uppermost pattern consisting of large elements, not touching each other; innermost pattern consisting of small elements forming a reticulate pattern, sometimes connected with the larger elements . . . . . . . . . A. salviifolium type

b. Uppermost pattern consisting of large elements forming a striate or rugulate pattern; innermost pattern consisting of small elements forming a reticulate pattern . . . .

7. a. The two different structure patterns only present in the region of the ectocolpus or

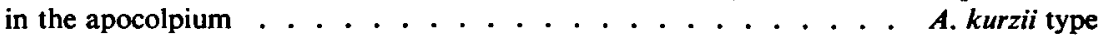

b. The two different structure patterns present both in mesocolpium and apocolpium ........................ platanifolium type

8. a. Sexine 1 consisting of short and thin columellae, sometimes not easily discernible $\quad 9$

b. Sexine 1 consisting of distinct, short and thick columellae . . . . . . . . . 17

9. a. Sexine 2 consisting of fused capita, elongate longitudinally . . . . . . A. kurzii type

b. Sexine 2 consisting of fused capita, rounded or elongate transversally . . . . . 10

10. a. Lumina of the structure pattern provided with small sexinous elements $A$. chinense type $B$

b. Lumina of the structure pattern without any sexinous element . . . . . . . 11

11. a. Costae of the endoaperture heavy, passing into costae ectocolpi . . . . . . 12

b. Costae of the endoaperture faint, no costae ectocolpi . . . . . . . . . . . 15

12. a. Endoaperture and costae bordered by a thinning of the nexine . . . . . . . 13

b. Endoaperture and costae not bordered by a thinning of the nexine . . . . . . 14

13. a. Ectocolpus bounded by the muri of the structure pattern or by an unthickened margo . . . . . . . . . . . . . . . . A. havilandii type

b. Ectocolpus bordered by a margo, thickened in the region of the endoaperture at least . . . . . . . . . . . . . . . . A. javanicum type

14. a. Ectocolpus bounded by the muri of the structure pattern or by an unthickened margo . . . . . . . . . . . . . . . A. maliliense type

b. Ectocolpus bordered by a margo, thickened in the region of the endoaperture at least

15. . . . . . . . . . . . . . . . . . chinense type D

5. a. Endoaperture and costae bordered by a thinning of the nexine . . . . . . 16

b. Endoaperture and costae not bordered by a thinning of the nexine $A$. chinense type A

16. a. Sexine/nexine ratio circa 1 . . . . . . . . . . . A. barbatum type

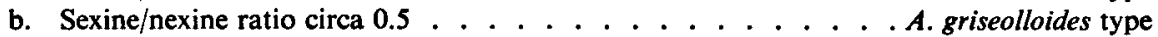

17. a. Costae of the endoaperture heavy, passing into costae ectocolpi . . . . . . 18

b. Costae of the endoaperture faint, no costae ectocolpi . . . . . A. griseolloides type

18. a. Ectoaperture and costae bordered by a thinning of the nexine . . . . . . 19

b. Endoaperture and costae not bordered by a thinning of the nexine . . . 20

19. a. Ectocolpus bounded by the muri of the structure pattern or by a not thickened margo ....................... havilandii type

b. Ectocolpus bordered by a margo, thickened in the region of the endoaperture at least ....................... javanicum type

20. a. Sexine/nexine ratio circa $0.5 \ldots \ldots \ldots$. . . . . . . . . . . . . . . . . type

b. Sexine/nexine ratio circa $1 \ldots \ldots$. . . . . . . griffithii type

DESCRIPTION OF THE POLLEN TYPES

A. chinense type $A$

(Plate I, II, III and IV, A-H; distribution: Fig.1)

Pollen grains (2-), 3-, 4-zonocolporate.

Ectoapertures: colpus, length varying from long to short; colpus membrane nudate or granulate; colpus bordered by a closed margo, thickened in the region of the endoaperture at least; colpus end distinct, obtuse. 
Endoapertures: lalongate colpus or lalongate, circular or lolongate porus; costae faint and mostly broad.

Ornamentation: eureticulate to eurugulate, sometimes eustriate in the region of the ectoaperture; lumina irregularly shaped, size varying; muri simpli-, dupli- or pluricolumellate.

Exine: $2-5 \mu$; sexine thicker than, as thick as or thinner than nexine; capita rounded; columellae thin and short.

Outline: equatorial view-elliptic; polar view-circular or, more often, 3- or 4angular with straight to convex sides and the apertures situated in the angles which are obtuse.

Measurements: longest axis $70-95 \mu ; \mathrm{P} / \mathrm{E}$ ratio:transverse to semitransverse.

Key to the subtypes

1. a. Sexine thinner than or as thick as nexine ........ subtype I

b. Sexine thicker than nexine. . . . . . . . . . subtype II

\section{Subtype I}

Sexine thinner than or as thick as nexine, exine 3-5 $\mu$.

Species: A. chinense in India and Asia (partly).

d'Alleizette s.n. (L), Atal Sing Dewan 65 (NY), Bloembergen 509 (BO, L), Ching 5486 (NY), Chow 574 (NY), Culta Hort. Bot. Calcutta s.n. (L), Jenkins s.n. (L), Kerr 1121 (L), Koeltz 4579 (NY), Koeltz 4771 (NY), Mohan Lal Punj 62 (NY), Pételot 4736 (NY), Prain's coll. s.n. (L), Rock 8873 (NY), Wallich 3719 (NY).

\section{Subtype II}

Sexine thicker than nexine, exine 2-4.5 $\mu$.

Species: $A$. chinense in Asia (partly).

Henry 10142 (NY), Henry 10647 (NY), Merrill and Swingle 11359 (NY), Pierre 573 (NY), Rock 10228 (NY), Rock 16125 (NY), Rock 24562 (NY), Steward and Cheo 706 (NY), Thorel s.n. (NY), Tsiang 5275 (NY), Tsiang 5343 (NY), Tso 21110 (NY), Wilson 501 (NY), Wilson 1134 (NY), Wilson 2757 (NY).

\section{Comments}

This type is characterized by the faint costae of the endoaperture. It is possible to distinguish two subtypes within this type on the basis of the sexine/ nexine ratio. The main distribution of subtype $I$ lies in the western part of the area, while that of subtype II is situated chiefly in the eastern part. It is sometimes difficult to determine the subtype, if only a single pollen grain is available. For this reason the present author decided to create subtypes instead of types for these two groups.

The structure pattern which determines the face of the pollen grain varies considerably (compare for instance Plate II, E-G, III, A-C and IV, F-H). 
It is not possible to attach any phytogeographical value to the latter feature. The same applies to the following features: length of the colpus; outline of the endoaperture; and outline of the pollen grain in polar view.

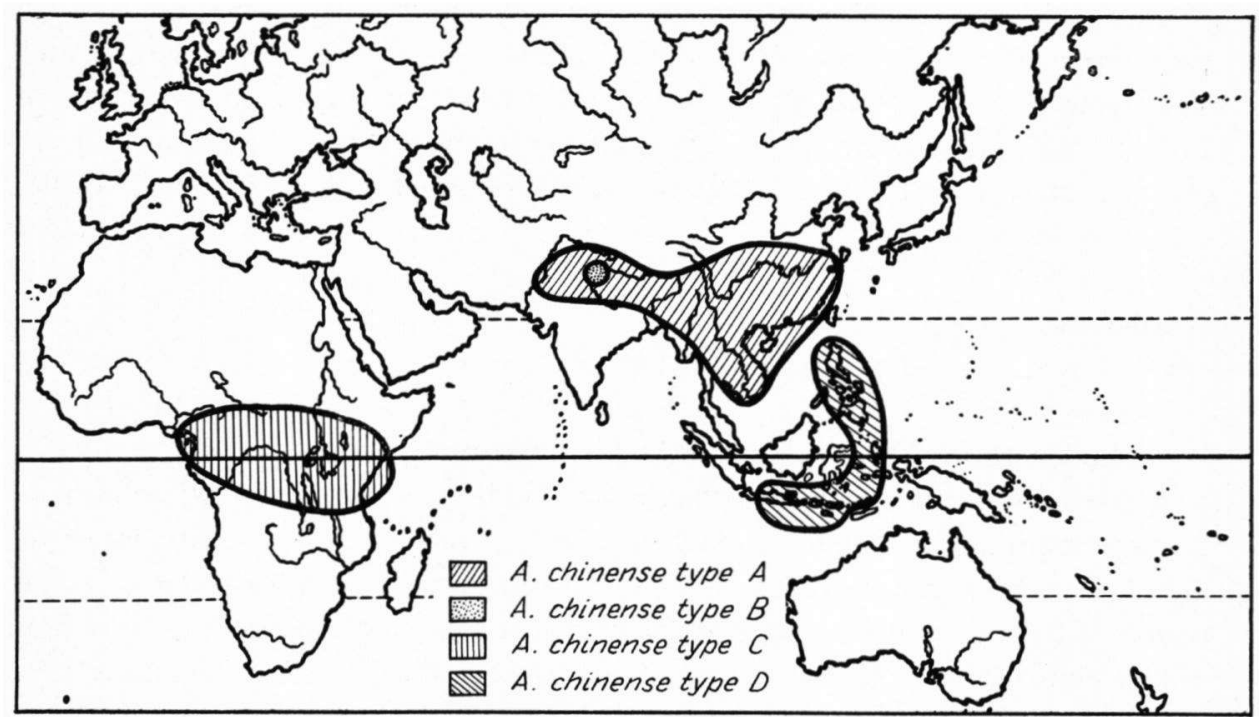

Fig.1. Distribution of the different types of Alangium chinense.

\section{A. chinense type B}

(Plate IV, J-M; distribution: Fig.1)

\section{Pollen grains 3-, 4-zonocolporate.}

Ectoapertures: colpus, length varying from long to short; colpus membrane granulate; colpus bordered by a closed margo, thickened in the region of the endoaperture at least; colpus end distinct, obtuse.

Endoapertures: lalongate colpus or lalongate, circular or lolongate porus, costae faint, broad or small.

Ornamentation: eureticulate to eurugulate; lumina irregularly shaped, larger than muri; lumina provided with small sexinous elements; muri simplicolumellate, sometimes dupli- or pluricolumellate.

Exine: 3-4 $\mu$; sexine thinner than nexine; capita rounded, columellae short and thin.

Outline: equatorial view-elliptic; polar view-circular or, more often, 3- or 4-angular with convex sides and apertures situated in the angles which are obtuse. Measurements: longest axis 74-81 $\mu$; $\mathrm{P} / \mathrm{E}$ ratio: transverse to semitransverse. 
Species: A. chinense in India (partly).

d'Alleizette 2971 (L), Bis Ram 2189 (NY).

\section{Comments}

This type is characterized by the small granules in the lumina. In all other features this type resembles type A subtype I. Since granules in the lumina have never been observed in any other pollen grains of Alangium, the present author holds that this group must have the rank of a type and not that of a subtype of the last type. However, it is also tenable to consider this group a subtype of the A. chinense type A, the more so as this group is found within the area of distribution of this type.

\section{A. chinense type $C$ \\ (Plate V and VI, A-D; distribution: Fig. 1)}

Pollen grains 3-zonocolporate or 3-zonopororate.

Ectoapertures: colpus, length varying from middle to short or porus; colpus- or porus membrane granulate; colpus or porus bordered by a closed margo or annulus, or bordered by relics of these, or bordered by a single element in the region of the endoaperture. In all these cases the sexine is thickened in the region of the endoaperture at least; end of colpus or porus distinct or indistinct, obtuse.

Endoapertures: lalongate, circular or lolongate porus, maximum breadth of the endoaperture larger than or equal to maximum breadth of ectoaperture; costae faint and mostly broad.

Ornamentation: sexine consisting of detached, rounded warts of different sizes; sexine elements easily coming off from nexine.

Exine: 2.5-8 $\mu$; sexine thicker than, as thick as or thinner than nexine; detached wart consisting of a single, rounded caput or of some capita, fused to a rounded element, of different height, length and breadth; columellae short and thin.

Outline: equatorial view-elliptic; polar view-circular or, more often, 3-angular with convex sides and apertures situated in the angles, which are obtuse.

Measurements: longest axis $65-80 \mu ; \mathrm{P} / \mathrm{E}$ ratio: semitransverse to subtransverse.

Species: $A$. chinense from Africa only.

Breteler 1376 (BR), Breteler 2884 (WAG), Bruce 453 (K), Deistel 579 (S), Donis 3943 (BR), Greenway 3309 (K), Lebrun 4936 (BR), Pierlot 329 (BR), Pierlot $3055(\mathrm{~K})$, Sangster $479(\mathrm{~K})$, Troupin 10231 (BR), Verdcourt 1716 (BR), Zenker $1416(\mathrm{~L})$. 


\section{Comments}

This type is characterized by the warty appearance of the pollen grain and by thickened sexine elements around the ectoaperture.

All African specimens of $A$. chinense belong to this type. These warty elements are characteristic of the pollen grains of the sections Alangium and Rhytidandra. It is amazing that this feature makes its appearance not in an entire species of the section Marlea but in a geographically restricted part of a good species. This is even more so as the taxonomists hold that the African specimens of $A$. chinense are conspecific with the remaining specimens. This opinion is, consequently, not supported by the pollen-morphological results.

The warty elements vary in size. The large elements are built up of several fused capita supported by columellae (Plate VI, A-D). The small elements between the large ones consist of a single caput and columella or of two fused capita. The shape of these warty elements varies considerably. The large elements easily come off from the nexine. It is possible to detect the place of attachment of these released elements (Plate $V, G$ ).

The length of the thickened sexine elements in the region of the aperture varies. Even in the pollen grains of a single flower it may occur that either the thickened sexine borders the whole ectocolpus (Plate $\mathrm{V}, \mathrm{C}$ ), or bounds nearly the whole ectocolpus (Plate V, A), or is only present in the region of the endoaperture (Plate V, B), or consists of a single warty element (Plate V, D, E). This feature has consequently no geographical value.

\section{A. chinense type $D$}

(Plate VI, E-K; distribution: Fig.1)

\section{Pollen grains (2-), 3-, 4-, (5-) zonocolporate.}

Ectoapertures: colpus, length varying from long to short; colpus membrane nudate or granulate; colpus bordered by a closed margo, thickened in the region of the endoaperture at least; costae; colpus end distinct, obtuse.

Endoapertures: Ialongate colpus or lalongate, circular or lolongate porus; costae heavy and broad.

Ornamentation: eureticulate to eurugulate; lumina irregularly shaped, size varying; muri simplicolumellate, very rarely duplicolumellate.

Exine: $3-4.5 \mu$; sexine thinner than or as thick as nexine; capita rounded, columellae thin and short.

Outline: equatorial view-elliptic; polar view-circular or 3-, 4- or 5-angular with convex sides and apertures situated in the angles which are obtuse.

Measurements: longest axis $73-91 \mu ; \mathrm{P} / \mathrm{E}$ ratio: transverse to semitransverse.

Species: $A$. chinense in Malaysia.

Boschpr. Ja 4394 (BO), Bur. Sci. 49289 Ramos and Edano (BO), Colfs 180 (L), 
Conklin 17542 (L), de Jong 38 (BO), De Voogd 2241 (BO), Edano 17791 (L), Elmer 10311 (NY), Koorders 1303 (L), For. Bur. 29767 Cenabre (NY), Kostermans 18099 (L), Ramos 978 (NY), Zollinger 2292 (L).

\section{Comments}

This type differs from the other types of $A$. chinense by its heavy costae of the endoaperture, which pass into costae of the ectocolpus. This feature is found in other species of the section Marlea as well as in nearly all species of the section Conostigma.

The number of apertures varies from two to five. In the northern part of the area (the Philippine Islands) the grains have mostly three apertures, sometimes two and, rarely, four. The number increases to the south of the area. The highest number (five) is found in Java. The same applies to the number of pollen grains with more apertures from one flower. All other varying features may occur in pollen grains of a single flower and have, consequently, no geographical value.

\section{A. kurzii type}

(Plate VII, VIII, IX and X; distribution: Fig.2)

Pollen grains 3- or 4-zonocolporate.

Ectoapertures: colpus, long; colpus membrane nudate or granulate; colpus mostly bordered by a closed or fractured margo, sometimes thickened in the region of the endoaperture; colpus end distinct, obtuse or acute.

Endoapertures: lalongate colpus or lalongate porus, very rarely lolongate; costae faint and mostly broad.

Ornamentation: eureticulate or eurugulate, mostly eustriate along the ectocolpi and in the apocolpium; sometimes a reticulate structure pattern is visible below the striate structure pattern; lumina regularly or irregularly shaped, the maximum width of the lumina larger than the maximum width of the muri; muri simplior duplicolumellate.

Exine: 3-7 $\mu$; sexine thicker than nexine; capita elongate longitudinally, varying in height; columellae short and thin; the large elements form a reticulate, rugulate or striate pattern, while the small elements form a reticulate pattern below the striate pattern.

Outline: equatorial view-elliptic; polar view-circular or, more often, 3- or 4-angular with straight to convex sides and apertures situated in the angles which are obtuse.

Measurements: longest axis $67-97 \mu ; \mathrm{P} / \mathrm{E}$ ratio: transverse to semitransverse.

Species: A. kurzii, A. rotundifolium. 


\section{Comments}

This type is characterized by the longitudinally elongate capita. Both A. kurzii and $A$. rotundifolium belong to this type. Although it is possible to recognize these two species on the bases of their pollen morphology in a few cases, but not in all, it is not justifiable to classify the two species into two separate types or subtypes. This pollen-morphologically close affinity of $A$. kurzii and A. rotundifolium confirms the taxonomic results.

BloEmbergen (1939) states already that one is inclined to unite A. kurzii and $A$. rotundifolium, without knowing the characters of the fruit. At the same time the suggested relationship of $A$. kurzii and $A$. chinense is not strengthened by the pollen-morphological results.

The capita can be fused at the top (Plate VIII, B, D), at the base (Plate VIII, B) or can be fused completely (Plate VIII, C, D). All these possibilities can occur even in a single pollen grain and for this reason the structure pattern can be very complicated (Plate VIII, A; Plate X, A-C).

In the region of the ectoaperture a striate pattern is usually present. However, pollen grains without a striate pattern in the region of the ectoaperture exist, especially in $A$. rotundifolium.

Sometimes the pollen grains show a tendency to form two structure patterns in two different levels of the sexine. This begins at the end of the ectocolpus (Plate X, A-C) and can expand over the apocolpium (Plate VII, C-F). This double pattern, however, is never found in pollen grains of $A$. rotundifolium.

The sexine is usually distinctly thicker than the nexine. However, some

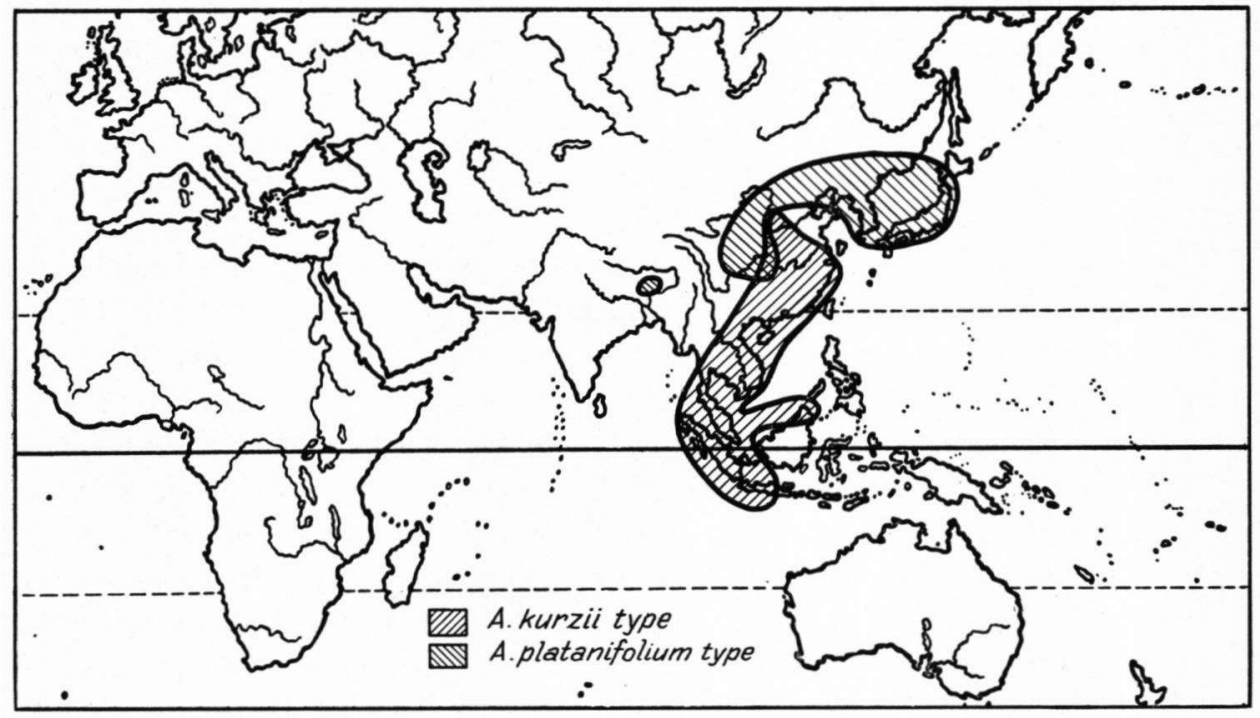

Fig.2. Distribution of the Alangium kurzil type and the A. platanifolium type. 
specimens of $A$. rotundifolium have pollen grains with a sexine and nexine of about equal thickness, especially in the southern part of the area of distribution.

\section{A. platanifolium type \\ (Plate XI and XII; distribution: Fig.2)}

\section{Pollen grains 3- or 4-zonocolporate.}

Ectoapertures: colpus, length varying from long to middle; colpus membrane nudate or granulate; colpus end distinct or indistinct, obtuse or acute.

Endoapertures: lalongate colpus or lalongate or circular porus, costae faint, broad or narrow.

Ornamentation: two different structure patterns are discernible in two different levels of the sexine. The uppermost structure pattern is a striate or rugulate one, the width of the lumina varies from wider than the muri to smaller than the muri, muri equally broad at base and top; the lowermost structure pattern is a reticulate one; this pattern can be quite independent of the uppermost pattern, but can also be connected with it; lumina of the reticulate pattern regularly shaped and larger than the muri.

Exine: 3-8 $\mu$; sexine thicker than nexine; sexine consists of large elements supported by thin and short columellae together forming the muri of the uppermost pattern and of much smaller elements also supported by thin and short columellae together forming the muri of the innermost pattern. Both elements are build up of several fused capita. The small and large elements can be fused.

Outline: equatorial view-elliptic; polar view-circular or 3- or 4-angular with convex sides and apertures situated in the angles which are obtuse.

Measurements: longest axis $80-110 \mu ; \mathrm{P} / \mathrm{E}$ ratio: semitransverse to subtransverse.

\section{Species: A. platanifolium, A. alpinum.}

\section{Comments}

This type is characterized by the double structure pattern in meso- and apocolpium, and by longitudinally elongate capita.

The type includes two species: $A$. platanifolium and $A$. alpinum. These two species cannot be distinguished pollen-morphologically, although they each have a quite different distribution pattern. The pollen-morphological results agree with the taxonomic ones. BLOEMBERGEN (1939) states that A. platanifolium comes nearest to A. alpinum. According to Bloembergen's opinion $A$. platanifolium has some affinities with $A$. chinense. This is not confirmed by the pollen-morphological results. Since some pollen grains of the $A$. kurzii type show a tendency to form a double structure pattern and all the grains have longitudinally elongate capita, it is likely that the $A$. platanifolium type comes nearest to the $A$. kurzii type.

The muri of both patterns are formed by fused capita, supported by short 
and thin columellae (Plate XII, C). The fused capita can be either large or small. The large capita form the muri of the uppermost pattern, while the small capita form the muri of the innermost pattern. Since the large capita can also be elongate in the breadth, it is possible that small muri are present beneath the large muri (Plate XII, C). For this reason it is possible that lumina are present under the muri of the uppermost pattern (Plate XII, D-G).

The uppermost pattern varies as the width of the lumina varies, while the width of the muri is constant. The same applies to the lumina of the innermost pattern.

\section{A. barbatum type}

(Plate XIII and XIV; distribution: Fig.3)

Pollen grains (2-), 3- (4-) zonocolporate.

Ectoapertures: colpus, length varying from long to middle; colpus membrane nudate or granulate; colpus bordered by a closed margo, thickened in the region of the endoaperture at least; colpus end distinct, obtuse or acute.

Endoapertures: lalongate porus, rarely circular or lolongate; costae faint and broad; endoaperture and costae surrounded by a thinning of the nexine.

Ornamentation: eureticulate to eurugulate; lumina irregularly or regularly shaped; lumina larger than or equal to muri; muri simplicolumellate.

Exine: $2.5-4.5 \mu$; sexine thicker than or as thick as nexine; capita rounded, columellae short and thin.

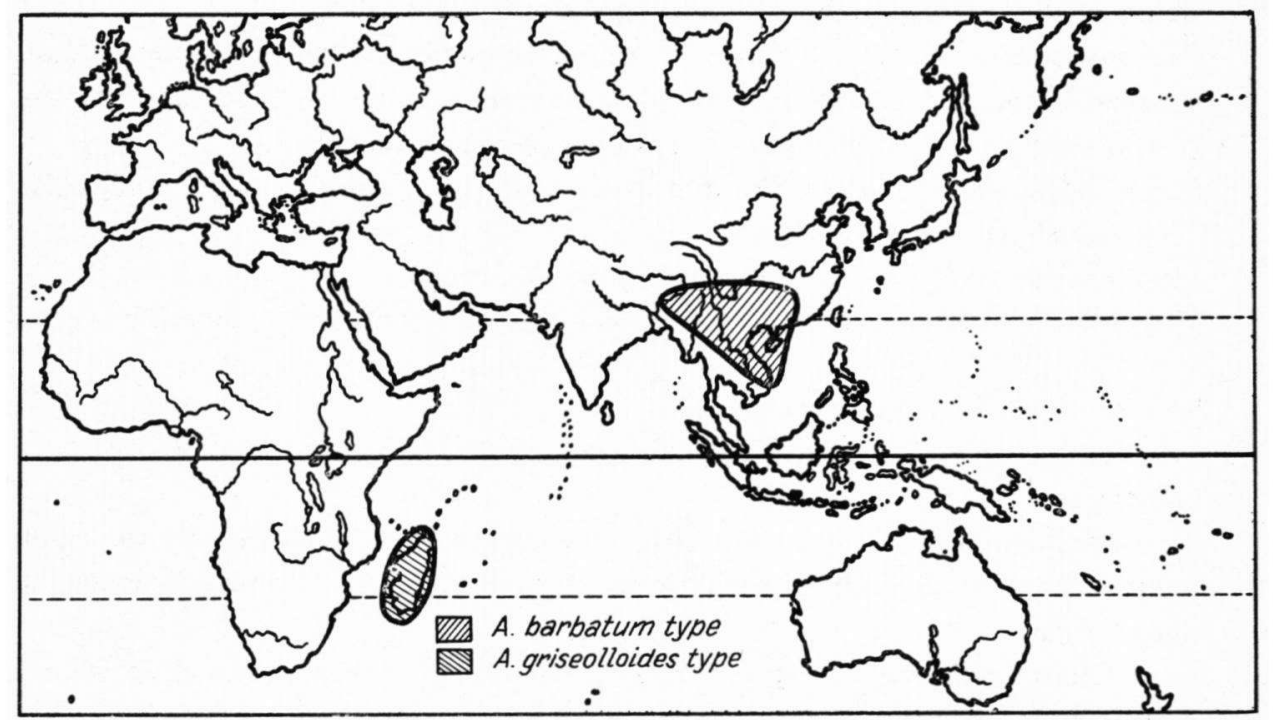

Fig.3. Distribution of the Alangium barbatum type and the A. griseolloides type. 
Outline: equatorial view-elliptic; polar view-3- or 4-angular with convex to straight sides and apertures situated in the angles which are obtuse.

Measurements: longest axis $57-65 \mu ; \mathrm{P} / \mathrm{E}$ ratio: transverse to semitransverse to subtransverse.

Species: A. barbatum.

\section{Comments}

This type is characterized by faint costae of the endoaperture and by a thinning of the nexine around costae and endoaperture.

The occurrence of this thinning separates this type from the remaining types of the section Marlea. This feature often appears in pollen grains of the species in the section Conostigma. This is in agreement with the opinion of BLOEMBERGEN (1939) that $A$. barbatum has some affinities with species of the section Conostigma, although the greater part of the characteristics points to a classification into the section Marlea. This is also confirmed by the pollen-morphological results.

\section{A. griffithii type}

(Plate XV and XVI; distribution: Fig.4)

Pollen grains 3- or 4-zonocolporate.

Ectoapertures: colpus, length varying from long to short; colpus membrane nudate or granulate; colpus bordered by a closed margo, sometimes thickened in the region of the endoaperture; costae; colpus end distinct, obtuse.

Endoapertures: lalongate, circular or lolongate porus; costae heavy and broad. Ornamentation: eureticulate to eurugulate; lumina irregularly shaped and varying in size; muri simplicolumellate, rarely dupli- or pluricolumellate.

Exine: 2-5 $\mu$; sexine thicker than or as thick as nexine; capita rounded; columellae thick and short.

Outline: equatorial view-elliptic; polar view-circular.

Measurements: longest axis $60-78 \mu ; \mathrm{P} / \mathrm{E}$ ratio: transverse to semitransverse.

Species: A. griffithii, A: scandens.

\section{Comments}

This type differs from all other types of the section Marlea by the thick columellae, which feature also may occur in pollen grains of some species of the section Conostigma.

The type includes the species $A$. griffithii and $A$. scandens. The close affinity of these two species is in accordance with the taxonomic results. Because of the thick columellae this type occupies a somewhat isolated position within the section 
Marlea. This is strengthened by the geographical distribution of these species. While the remaining species of the section Marlea have their main distribution in Asia and India with some offshoots in the direction of Africa and Malaya, this type is restricted to the Indonesian archipelago.

It is generally possible to distinguish the pollen grains of $A$. griffithii and $A$. scandens from each other. Pollen grains of $A$. griffithii usually have a margo thickened in the region of the endoapertures and an ectocolpus which is middle to short. Pollen grains of $\boldsymbol{A}$. scandens have an unthickened margo and an ectocolpus which is middle to long. However, the thickening of the margo can be so trifling, that it is hardly possible to ascertain whether a thickening is present or not without studying other pollen grains of $A$. griffithii and $A$. scandens. Because transitions are present between a thickened and an unthickened margo, I do not feel justified in classifying the pollen grains of these species into two different subtypes. If the features are clear, it is possible to distinguish the species pollen-morphologically.

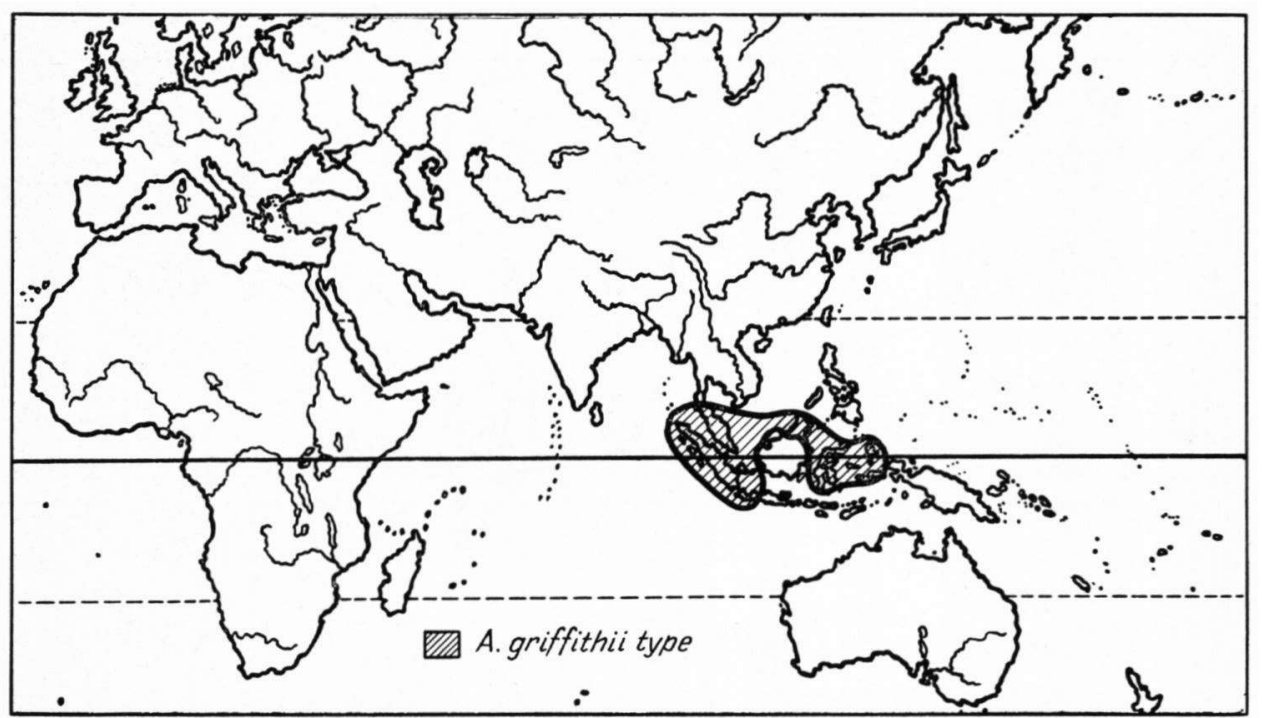

Fig.4. Distribution of the Alangium griffithii type.

\section{A. nobile type}

(Plate XVII; distribution: Fig.5)

Pollen grains (2-), 3- or 4-zonocolporate.

Ectoapertures: colpus, length varying from long to middle; colpus membrane nudate or granulate; colpus bordered by a margo, thickened in region of the endoapertures; costae; colpus end distinct, obtuse.

Endoapertures: lalongate, circular or lolongate porus; costae heavy and broad. 
Ornamentation: eureticulate to eurugulate; lumina irregularly shaped, varying in size; muri simpli-, dupli- or pluricolumellate.

Exine: 3-5.5 $\mu$; sexine thinner than nexine; columellae short and thick.

Outline: equatorial view-elliptic; polar view-circular or 3-, or 4-angular with convex sides and apertures situated in the angles which are obtuse.

Measurements: longest axis $60-88 \mu ; \mathrm{P} / \mathrm{E}$ ratio: semitransverse to transverse.

Species: A. nobile.

\section{Comments}

This type is characterized by the thick columellae, the thickened margo and the heavy costae of the endoaperture.

The type has some affinities with the $A$.griffithii type. The difference between these types lies in the sexine/nexine ratio. This ratio is circa 1 in pollen grains of the $A$. griffithii type and circa 0.5 in those of the A. nobile type. The affinities with the other species of the section Conostigma are rather obscure.

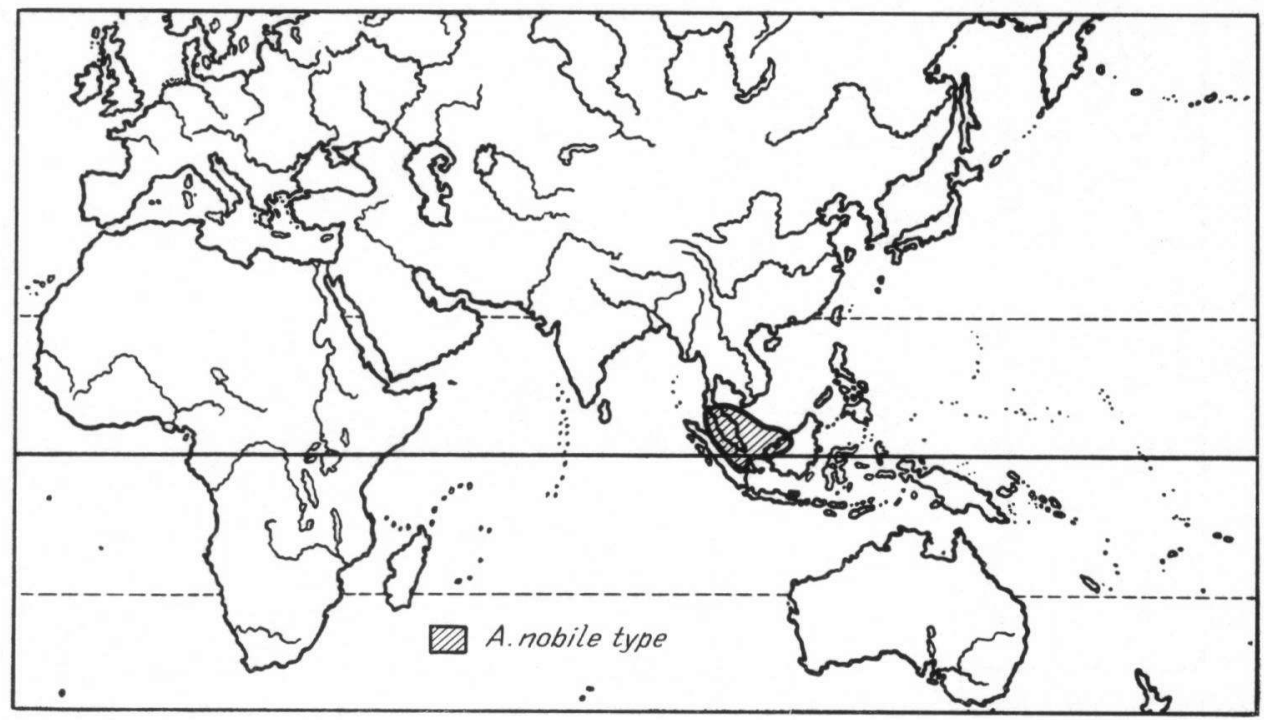

Fig.5. Distribution of the Alangium nobile type.

\section{A. javanicum type}

(Plates XVIII, XIX, XX, XXI and XXII; distribution: Fig.6)

Pollen grains (2-), 3- or 4-zonocolporate.

Ectoapertures: colpus, length varying from long to short; colpus membrane nudate or granulate; colpus bordered by a margo, thickened in the region of the endoaperture at least; costae; colpus end distinct, obtuse or acute. 
Endoapertures: lalongate colpus or lalongate or circular or lolongate porus; costae heavy and broad; endoaperture and costae bordered by a thinning of the nexine.

Ornamentation: eureticulate, eurugulate, or sometimes the sexine consisting of more or less detached elements of different shapes, formed by fused capita; lumina irregularly shaped; varying in size; muri simpli-, dupli- or pluricolumellate.

Exine: 2-6 $\mu$; sexine thinner than nexine; columellae short, thin or thick.

Outline: equatorial view-elliptic; polar view-circular or 3-, or 4-angular with straight to convex sides, and apertures situated in the angles which are obtuse. Measurements: longest axis 55-95 $\mu$; $\mathrm{P} / \mathrm{E}$ ratio: semitransverse to transverse.

Species: A. javanicum, A. ridleyi.

\section{Comments}

This type is characterized by heavy costae of the endoaperture, thickened margo and a thinning of the nexine around the endoaperture and the costae.

The type includes two species, $A$.javanicum and $A$. ridleyi. No differences exist between the pollen grains of both species. This confirms Bloembergen's statement that: "the two species are closely related to each other and that it is doubtful whether $A$. ridleyi is not a form of the widely spread and polymorphic $A$. javanicum".

Because BlOEMBERGEN (1939) wrote that $A$. javanicum is a polymorphic species, it seemed interesting to trace how far the pollen grains also showed any variation.

It very soon appeared that the pollen grains showed a considerable variation, especially concerning the structure pattern, the number of the apertures, the length of the ectoapertures, the outline in polar view, the outline of the endoapertures and the thinning of the nexine around the endoaperture, and that some features had been fixed geographically.

The structure pattern varies from reticulate (Plate $X X, B-G$ ), to rugulate (Plate XX, L-Q) to more or less detached elements (Plate XXI, A-J). The lumina can be either large (Plate XIX, E, Plate XX, B-D) or small (Plate XX, E-Q). The muri are simplicolumellate (Plate XX, B-D), duplicolumellate (Plate XX, $\mathrm{O}-\mathrm{Q}$ ) or pluricolumellate (Plate XXI, A-B). It appears that the reticulate patterns are mostly found in the southwestern, southern and southeastern part of the area and in northwestern Borneo. The other patterns are found in particular in the remaining part of Borneo and New Guinea.

The usual number of apertures is three. Sometimes 2- or 4-aperturate pollen grains are found. In the southeastern part of the area (Solomon Islands) 2-aperturate grains frequently occur. In the northern and western part of the area 4 aperturate pollen grains are occasionally found.

The length of the ectocolpus varies from long to short. The longest ectocolpi are found in the Solomon Islands and in northwestern Borneo. A tendency is 
apparent for the ectocolpi to become shorter over an area extending from the Solomon Islands to Celebes and the Philippine Islands. The same applies from northwestern Borneo to the western and southern part of the area.

The outline of the endoaperture varies considerably. Even in the pollen grains of a single flower the endoaperture can be a lalongate colpus, a lalongate porus, a circular porus or a lolongate porus. Apparently the outline of the endoaperture is genetically rather uncontrolled.

The thinning of the nexine around the endoaperture varies from distinct (Plate XXII, C and Plate XIX, B, C, D) to rather indistinct (Plate XIX, A and Plate XXI, A, B, E, F). In the latter case the thinning can be easily overlooked and unless one is very carefull, and then it is easy to confuse these pollen grains with grains of the $A$. chinense type $\mathrm{D}$. It appears that this thinning has its optimum development in the centre of the present area of distribution, e.g., in Borneo and New Guinea.

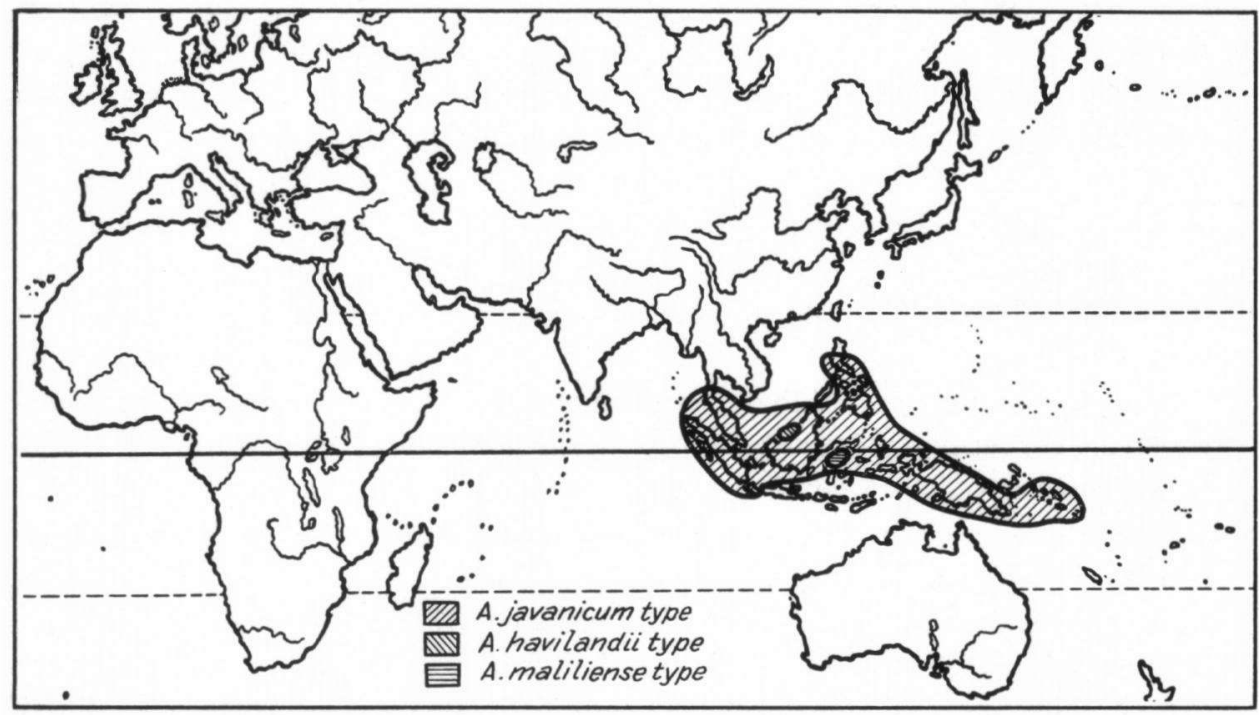

Fig.6. Distribution of the Alangium javanicum type, the $A$. maliliense type and the $A$. havilandii type.

\section{A. havilandii type}

(Plate XXIII; distribution: Fig.6)

Pollen grains 3-zonocolporate.

Ectoapertures: colpus, length varying from long to middle; colpus membrane nudate or granulate; colpus bordered by the muri of the structure pattern or by an unthickened margo; costae; colpus end distinct, obtuse.

Endoapertures: lalongate porus; costae broad and heavy; endoaperture and costae bordered by a thinning of the nexine. 
Ornamentation: eureticulate to eurugulate; lumina irregularly shaped, varying in size; muri simpli-, dupli- or pluricolumellate.

Exine: 3-4.5 $\mu$; sexine thinner than nexine; columellae short, thin or thick.

Outline: equatorial view-elliptic; polar view-circular or 3-angular with convex sides and apertures situated in the angles which are obtuse.

Measurements: longest axis $66-80 \mu$; $\mathrm{P} / \mathrm{E}$ ratio: semitransverse to transverse.

Species: A. havilandii.

\section{Comments}

This type differs from the A. javanicum type by the limitation of the ectocolpus. While in the preceding type the ectocolpus is bounded by a thickened margo, in this type the ectocolpus is bounded by an unthickened margo or by the muri of the structure pattern. Consequently, these two pollen types are closely related. BLOEMBERGEN (1939) mentions that $A$. havilandii is closely allied to $A$. nobile by the characters of the flower. However, it approaches $A$. ridleyi and $A$. javanicum through the character of the leaves. Pollen-morphologically the affinity with $A$. nobile is obscure.

\section{A. maliliense type}

(Plate XXIV; distribution: Fig.6)

Pollen grains 3- or 4-zonocolporate.

Ectoapertures: colpus, middle; colpus membrane nudate; colpus bordered by the muri of the structure pattern or by an unthickened margo; costae; colpus end distinct or indistinct, obtuse.

Endoapertures: lalongate, circular or lolongate porus; costae heavy and broad. Ornamentation: eureticulate or eurugulate; lumina irregularly shaped, smaller than muri; muri simpli-, dupli- or pluricolumellate.

Exine: 2-3.5 $\mu$; sexine much thinner than nexine; columellae short and thin. Outline: equatorial view-elliptic; polar view-circular or 3-, or 4-angular with convex sides and apertures situated in the angles which are obtuse.

Measurements: longest axis 56-65 $\mu$; P/E ratio: semitransverse to transverse.

\section{Species: $A$. maliliense.}

\section{Comments}

This type differs from the $A$. havilandii type only by the absence of the thinning of the nexine around the endoaperture. In all remaining features both types agree with each other, though there are, however, some slight differences, e.g., the size of the pollen grains and the thickness of the sexine.

BLOEMBERGEN (1939) observed a strong relationship with $A$. javanicum, 
A. ridleyi and $A$. havilandii, which has been confirmed by the pollen-morphological results.

\section{A. griseolloides type}

(Plate XXV; distribution: Fig.3)

Pollen grains 3-zonocolporate.

Ectoapertures: colpus, long; colpus membrane nudate or granulate; colpus bordered by a margo, sometimes thickened in region of endoaperture; colpus end distinct, obtuse.

Endoapertures: lalongate colpus or lalongate porus; costae faint and narrow; endoaperture and costae bordered by a thinning of the nexine.

Ornamentation: eureticulate; lumina regularly shaped, larger than or sometimes equal to muri; muri simplicolumellate.

Exine: 3-4 $\mu$; sexine thinner than nexine; columellae short, either thick or thin. Outline: equatorial view-elliptic; polar view-3-angular with convex sides and apertures situated in the angles which are obtuse.

Measurements: longest axis 54-62 $\mu$; P/E ratio: semitransverse to subtransverse.

\section{Species: $A$. griseolloides.}

\section{Comments}

This type differs from all other types in the section Conostigma by the faint costae of the endoapertures. It comes near to the $A$. barbatum type, from which it only differs in connection with the sexine/nexine ratio. In the pollen grains of A. barbatum this ratio is circa 1 , while in the grains of this type the ratio is circa 0.5. It is impossible to incorporate $A$. griseolloides in either the section Marlea or Conostigma on the basis of pollen characters, because both sections cannot be defined pollen-morphologically. Both sections break up into several pollen types. Capuron (1962) and Eyde (1968) came to the conclusion that on the basis of both flower and fruit characteristics $A$. griseolloides should be included in the section Conostigma, although not all the characteristics point to this affinity.

\section{A. salviifolium type}

(Plate XXVI, XXVII, XXVIII and XXIX; distribution: Fig.7)

Pollen grains (3-) 4-, 5-, 6-, (7-, or 8) colporate or pororate or partly colporate and pororate; mostly zonoaperturate; sometimes the apertures are situated partly in an equatorial zone and partly elsewhere; some grains have one or two single ectoapertures or one or two single endoapertures, together with compound apertures.

Ectoapertures: colpus, length varying from long to short or porus, rarely absent; 
aperture membrane nudate or granulate; sometimes ectoaperture bordered by a not thickened margo; colpus and porus end distinct or indistinct.

Endoapertures: lalongate, circular or lolongate porus, rarely absent; costae faint, either broad or narrow.

Ornamentation: exine consisting of rounded more or less detached warts of different sizes; small elements sometimes arranged in a reticulate pattern with wide and irregularly shaped lumina, muri simpli- or dupli- or pluricolumellate.

Exine: 4-9 $\mu$; sexine thicker than, as thick as or thinner than nexine; detached warts consisting of capita, fused to more or less rounded elements, of different height and breadth; columellae short and thin.

Outline: equatorial view-elliptic; polar view-circular or 4-, 5- or 6-angular with straight to convex sides and apertures situated in the angles which are obtuse. Measurements: longest axis 60-95 $\mu ; \mathrm{P} / \mathrm{E}$ ratio: semitransverse to subtransverse.

\section{Species: A. salviifolium, A. longifolium, A. brachyanthum.}

\section{Comments}

This type is characterized by the more or less detached elements, which give the grain a warty appearance, and by the ectoapertures which are not sunken.

The type comprises the whole section Alangium. This agrees with the taxonomic results. BLOEMBERGEN (1939) notes that it is not impossible that transitions between $A$. salviifolium and $A$. longiflorum occur and that $A$. brachyanthym may later prove to be a variety of $A$. longiflorum, if more material of this species is collected.

Since the species of this type are more or less sympatric with $A$. chinense, the obvious course is to trace whether any geographically defined types can be also found in this type. It is striking, however, that these species do not appear to show any geographically defined types, although the pollen grains vary considerably.

The pollen grains of this type show a remarkable resemblance with the pollen grains of the African specimens of $A$. chinense. In fact the differences between these two types are slight, one being the number of apertures. In the $A$. chinense type $\mathrm{C}$ this number is always three, while in this type very rarely three apertures occur. EYDE et al. (1969) mention one specimen of $A$. salviifolium (Nusker 25) from India, of which all the pollen grains have three apertures. However, among all the plant specimens studied by the present author, there was none in which all pollen grains had three apertures. In some specimens a portion of the grains had three apertures, but this portion always constituted a low percentage. Another difference is that the pollen grains of $A$. chinense type $\mathrm{C}$ have a thickened sexine along the ectocolpi, while the pollen grains of this type do not show this feature.

The ectocolpus varies from long to short (Plate XXVII, A-D). Sometimes 
the ectocolpus changes into an ectoporus (Plate XXVII, E). Rarely, the ectoaperture is completely absent (Plate XXVII, F). It is also possible that some ectocolpi fuse (Plate XXVII, D).

The endoaperture is mostly a porus. This porus can be either lalongate, or circular, or lolongate. Rarely, the endoaperture divides into two parts (Plate XXVIII, B) or even into three parts (Plate XXVIII, C) or is completely absent (Plate XXVII, H).

The apertures are mostly situated in the equatorial zone, although sometimes one or two apertures are present in the apocolpium or apoporium. Sometimes the pollen grains are loxocolporate (Plate XXVIII, A).

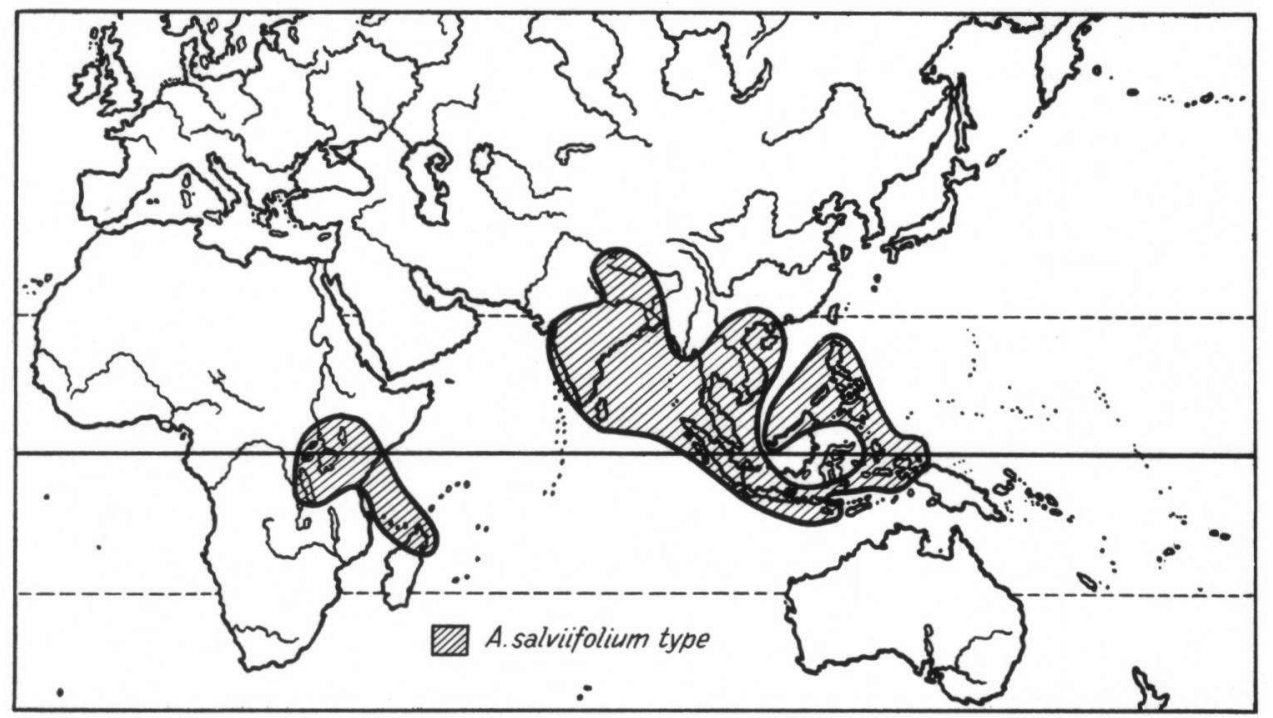

Fig.7. Distribution of the Alangium salviifolium type.

\section{A. villosum type}

(Plate XXX, XXXI, XXXII; distribution: Fig.8)

Pollen grains 3-, 4-, 5- or 6-zonocolporate

Ectoapertures: colpus, length varying from long to middle, sunken; colpus membrane nudate; colpus edge consisting of detached sexine elements; colpus end distinct, obtuse or acute.

Endoapertures: lalongate, circular or lolongate porus; costae faint.

Ornamentation: pollen grains provided with detached, rounded or angular elements of different height and breadth; sometimes the small elements arranged in a reticulate pattern.

Exine: 4-7 $\mu$; sexine thicker than nexine; elements consisting of two or more fused capita supported by short and thin columellae. 
Outline: equatorial view-elliptic; polar view-circular or, more often, 3-, 4-, 5or 6-angular with convex sides and apertures situated in the angles, which are obtuse.

Measurements: longest axis $45-75 \mu ; \mathrm{P} / \mathrm{E}$ ratio: semitransverse to subtransverse.

Species: A. villosum.

\section{Comments}

This type is characterized by the warty appearance of the pollen grains and by the sunken ectocolpi.

The type comprises the section Rhytidandra. BLOEMBERGEN (1939) subdivides A. villosum, the only species of this section, into ten subspecies. According to Bloembergen's opinion the subspecies are either members of a group of closely allied and little-differing good species or geographical varieties of one or perhaps two polymorphic species. The pollen-morphological results support the opinion that the subspecies belong to one good species.

The greater part of the pollen grains have four or five apertures. Sometimes there are only three apertures (ssp. bussyanum, New Caledonia) or 3-aperturate pollen grains occur together with 4- or 5-aperturate ones (ssp. vitiense, Fiji Islands and ssp. parviflorum, Sunda Islands). A. villosum ssp. polyosmoides differs from the remaining subspecies by larger pollen grains and the occurence of 6-aperturate pollen grains together with 5- and, rarely, 4-aperturate ones. It may be possible that this subspecies is a polyploid form of one of the other subspecies.

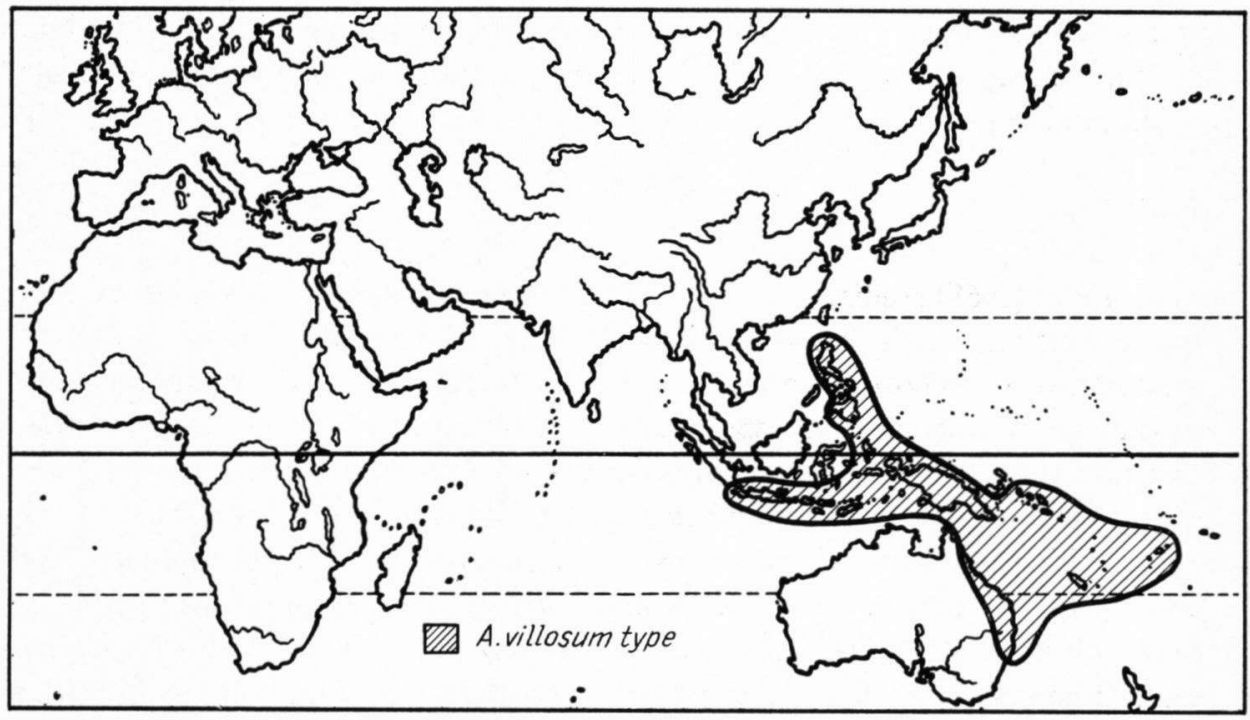

Fig.8. Distribution of the Alangium villosum type. 
In this post-Darwinian period evolution of plant organs is a generally accepted concept (DAvis and HeYwOOD, 1963). Since these plant organs, on their turn, consist of several units, it seems logical to accept that these units can evolve separately. The pollen grain is such a unit.

Evolution can only be demonstrated if fossil data are available. For this reason it is necessary to search for fossil material as much as possible, if one would pay some attention to evolution. Because pollen grains are the topic of this study, great emphasis is laid upon the fossil pollen grains. Nevertheless other fossil plant parts are not to be neglected, since they may give additional information regarding the possible relationship of the fossil material with the recent species.

The fossil records of Alangium known up till now are largely Tertiary, although some remains are found in Pleistocene or Holocene deposits. As far as is known to the present author no convincing Alangium fossils are present in horizons older than the Tertiary. According to the literature the findings include leaf remains, fruits, wood, and pollen grains. For convenience the records can be treated in four parts, corresponding to the plant parts preserved.

\section{Leaves}

EYDE et al. (1969) give an extensive review of Tertiary leaf remains. The authors show a sceptic attitude towards the identification of the leaf impressions, as many of the recent species of Alangium cannot be indentified on the basis of leaf character alone (BLOEMBERGEN, 1939). Therefore, as already stated by EYDE et al. (1969) cuticular analysis is necessary to support identification. Without cuticular analysis it is not certain whether the putative Alangium leaves really belong to the genus Alangium (see also Givulescu, 1970).

\section{Fruits}

EYDE (1968) studied the endocarps of recent Alangium species. He came to the conclusion that it was possible to separate the four infrageneric sections of BLOEMBERGEN (1939) on the basis of endocarp features. It was even sometimes possible to distinguish some species. With these results EYDE et al. (1969) tried to compare the fossil fruit remains with fruits of recent species. They described a new species, Alangium vermontanum, of the Brandon Lignite, which they compared with some selected specimens of $A$. chinense and $A$. platanifolium. According to EYDE et al. (1969) A. vermontanum shows a remarkable resemblance to the German Miocene fossils described by KIRCHHEIMER (1936) as Carpolithus sp. I. Although they state that: "in fact the characters of the Brandon fossils overlap those of the Salzhausen fossils, and we doubt that we could identify all of our 
Alangium vermontanum specimens if they were mixed with a selection of wellpreserved Carpolithus sp. I", yet they feel justified in separating A. vermontanum from the German specimens. Their arguments in support of this separation are that the slight differences in size and position of the abortive carpel are about as great as the differences between endocarps of the most closely related modern species in the section Marlea. In my opinion the fruits collected in both deposits belong to the same plant species, since the pollen grains found in both deposits are completely identical (KruTzSCH, 1962).

A number of Alangium fruits are found in Japan. MIKI (1956) and MIKI and KoKawa (1962) listed all the Alangium fruit remains of Japan. Fruits from several Pliocene deposits were identified as $A$. begoniifolium. This species has been split up by Bloembergen (1939) into three species, viz., A. chinense, A. kurzii and $A$. rotundifolium. According to EYDE et al. (1969) these fruits must be compared with $A$. chinense. One fruit of a Pleistocene deposit was identified as $A$. platanifolium and some fruits from recent deposits as $A$. premnifolium, probably identical with $A$. kurzii.

Chandler (1961) described A. jenkinsii, an Eocene species belonging to the section Marlea, of the London Clay.

Wood

AwaSTHI (1968) described Alangioxylon scariforme. This fossil wood was collected in the neighbourhood of Pondicherry, Madras, southern India, in middle Tertiary deposits (Cuddalore Series). According to Awasthi this fossil wood resembles in all anatomical details recent Alangium, and probably one or another species of the section Conostigma. As far as the present author knows, this was the first record of fossil Alangium wood.

\section{Pollen grains}

Additional reports of Alangium pollen grains appear in palaeobotanical literature since 1955. TRAVERSE (1955) was the first who described the finding of a solitary Alangium pollen grain, A. barghoornianum, from the Brandon Lignite. A. barghoornianum can be compared with some species of the section Marlea. Numerous records of $\boldsymbol{A}$. barghoornianum have been published after Traverse's find, from a number of European localities. KRUTzSCH (1962) listed five German localities of Early Miocene and Middle Oligocene age. He transferred the generic name Alangium into Alangiopollis, for the reason that the fossil pollen grains can be related to those of the modern genus Alangium, although it is not quite certain that they are congeneric. PACltova $(1963,1966)$ reported Alangiopollis barghoornianus (not barghoornianum) from Czech localities of Late Oligocene or Early Miocene age. NAGY (1962) discovered some pollen grains in a Lower Miocene deposit in Hungary. 
KRUTZSCH (1969) isolated a new Alangiopollis species from Eocene deposits in Eastern Germany, which he named $A$. eocaenicus. He compared this species with the recent species Alangium griseolloides, belonging to the section Conostigma, only known from Madagascar.

Chandler (1964) listed Alangium sp. in the pollen flora of the London Clay. This Alangium sp. has been described and illustrated by SEIN (1961) in her $\mathrm{Ph}$. D. thesis. I was unable to consult this thesis, but I had the opportunity to study her slides. It appeared that her Alangium sp. was identical with Alangiopollis eocaenicus.

FAIRCHILD and ELSIK (1969) give an illustration of a "large nyssoid pollen grain" common in Lower Tertiary sediments of the Gulf Coast (their fig. 49). From this illustration it is clear that the pollen grain is not Nyssa sp. but Alangiopollis eocaenicus.

According to MCHEDLISHVILI and SAMOILOvich (1962) Ljubomirova described Alangium sibiricum from Oligocene deposits in western Siberia. Unfortunately it was not possible to consult the original description, and for this reason it is impossible to fit this species into the Tertiary Alangium remains.

Cookson (1957) described Alangium javanicoides from Upper Pliocene sediments of New Guinea. She compared these pollen grains with pollen grains of the recent $A$. javanicum.

MUlLer (1964) mentions Alangium as one of the pollen types being found in Tertiary deposits in Borneo, while PuRI (1964) mentions it from Tertiary sediments in Nigeria. SATo (1963) reported Alangium pollen grains in Miocene sediments of Hokkaido (Japan).

As mentioned above, AWASTHI (1968) described a fossil Alangium from Miocene deposits in southern India. Since this Miocene lignite has been studied palynologically by Ramanujam (1966), it was possible to look for Alangium pollen grains in his paper. Unfortunately he did not describe any pollen grain under the name Alangium or Alangiopollis. From the photographs (RAmanuJam, 1966, p.175, pl. IV, 71, 72 and 73) it appeared, however, that these pollen grains showed some affinity to Alangium. Ramanujam created the new genus Margocolporites for these pollen grains. This genus is characterized by a margocolporus, a term defined by TsUKADA (1963). When studying the pollen morphology of the Eucaesalpinieae he defined this term as follows: "a margocolporus is characterized by an equatorially wide and longitudinally elongated furrowlike streak with a short colpus and an os in the centre of each margocolporus, provided with somewhat thick and distinctly sculpturate ectexine, probably compacted, ectexinous rods. Its pattern is easily distinguishable from the reticulate pattern in mesocolpia". It is obvious from Ramanujam's plate IV that some of the species of Margocolporites, e.g., M. complexus and $M$. dubius, do not show a margocolporus at all. In my opinion these grains are certainly not related to those of the Caesalpiniaceae. Judging from his descriptions it may be possible that these species 
have affinities with the section Marlea. However, this affinity does not correspond to the probable affinity of Alangioxylon scariforme with the section Conostigma.

COMPARISON OF FOSSIL AND RECENT POLLEN GRAINS

If we try to compare the fossil pollen remains with recent ones, it appears that, except for Alangiopollis javanicoides, all remains are referable to the section Marlea. A. eocaenicus has been compared by KRUTZsCH (1969) with Alangium griseolloides belonging to the section Conostigma. The sexine of Alangiopollis eocaenicus is, however, thicker than the nexine and this feature is only found in some species of the section Marlea. The combination of these features i.e., sexine thicker than nexine and reticulate pattern, occurs only in pollen grains of the Alangium kurzii type, the $A$. barbatum type and the $A$. chinense type A. The main difference between these pollen types lies in the shape of the capita or, when they are fused, in the outline of the muri in transversal section. This outline can be either elongate longitudinally, rounded or elongate transversely. It is obvious from Plate XXXIII that the outline in the fossil grains is more or less rounded. For this reason Alangiopollis eocaenicus must be related to the Alangium chinense type A or the Alangium barbatum type. Pollen grains of both types possess faint costae of the endoaperture, but pollen grains of the A. barbatum type have a thinning of the nexine around the endoaperture. This feature is not found in the fossil pollen grains. So Alangiopollis eocaenicus can only be related to Alangium chinense type $\mathrm{A}$, if it has any relationships, for this affinity is not clear. There are features in the fossil pollen grain which do not occur in a single recent pollen grain, but which occur in different types. For instance, the colpus edge of the fossil pollen grain is formed by the muri of the reticulum. This feature occurs only in some pollen grains of $A$. maliliense and $A$. havilandii (section Conostigma). KRUTZSCH (1969) reports the finding of both transverse and erect grains, a feature which is found only in some abnormal pollen grains of $A$. griseolloides (STRAKA and SimON 1967).

In spite of all these differences I certainly believe that these fossil pollen grains belong to the Alangiaceae. The find of an Alangium fruit in the London Clay confirms this possibility. If this assumption is correct, then the fossil may be regarded as one of the ancestors of the recent species, especially those of the section Marlea.

Alangiopollis barghoornianus has been compared by TRAVERSE (1955) with pollen grains of Alangium chinense. KRUTZSCH (1962) and EYDE et al. (1969) mention $A$. kurzii as the nearest modern counterpart of the fossil. From the present study it appears that the fossil pollen grains are identical with the recent $A$. kurzii type and fall within the range of variation. Affinity with $A$. chinense is out of the question since the capita of the fossil pollen grains are elongate lengthwise. Because the fossil pollen grains have a single structure pattern and 
not two different patterns in different levels of the sexine, the fossil pollen grains are not related to $A$. platanifolium or to $A$. alpinum. Since the $A$. kurzii type includes the species $A$. kurzii and $A$. rotundifolium, it is not possible to state with certainty the relationship to a recent species.

As Cookson (1957) already stated, Alangiopollis javanicoides is virtually indistinguishable from the grains of Alangium javanicum. As mentioned before the species Margocolporites dubius and $M$. complexus (not complexum), described by Ramanujam (1966), show some relationship to Alangium section Marlea. The sexine of these fossil grains is about as thick as the nexine; the ectocolpus is bounded by a thickened margo; the costae of the endoaperture are faint; the reticulate pattern have simplicolumellate muri and thin and short columellae and the endoaperture is lolongate. The combination of this features is found in two types of Alangium chinense, namely type A and type B. According to the granules in the lumina which feature is found in Margocolporites complexus, it is possible that $M$. complexus is related to the Alangium chinense type B. Margocolporites dubius should be related to Alangium chinense type A.

Since Sato (1963), Muller (1964) and PurI (1964) do not give illustrations of their fossil Alangium pollen grains, it is impossible to classify these pollen grains in any pollen type or even in a section.

\section{EVOLUTIONARY TRENDS}

If it is accepted that evolution actually took place, this evolution must be supported by as much data as possible, e.g., palaeobotanical, phytogeographical and taxonomic data. It is a pity that BLOEMBERGEN (1939) does not pay attention to the evolutionary relationships within the genus Alangium. For this reason it is difficult to trace which species should be considered the most primitive species, and which the most advanced, on the basis of phytomorphological characters. It is the more unfortunate since it is accepted (PUNT, 1967), that primitive plants also have pollen grains which show the most primitive characteristics.

The question arises as to what is meant by primitive and advanced. Primitive is not an absolute conception but a relative one, and the same applies to advanced. Since angiosperms originated during Mesophytic times, one is allowed to postulate, that these plants have pollen grains of a primitive character in comparison with pollen grains of plants occurring in younger periods. In every stage of the evolution a characteristic can be regarded as primitive in comparison with those of the next stages but advanced in comparison with the characteristics of the last stages. Another example of this relativity is the fact that some pollen grains of recent species of Alangium can be considered primitive in comparison with pollen grains of other Alangium species, although the primitive pollen grains of Alangium are advanced in comparison with other pollen types of the Angiospermae. 
I should like to call the succession or probable succession of a pollen character from primitive to advanced an "evolutionary trend" (PUNT, 1967; PUNT and LeENHOUTS, 1967). This term holds that succession is only possible in one direction, viz., from primitive to advanced. In contradiction to an evolutionary trend, a "morphological series" means that a succession of transitions exists, but that the direction of this succession is uncertain.

As mentioned above, Bloembergen did not give any information about primitive and advanced species of Alangium. However, it is possible to obtain some information about the evolution of this genus, because palaeobotanical data are available.

As pointed out before Alangiopollis eocaenicus KrutzSCH is the oldest Alangium pollen grain known up till now. The features of these pollen grains are:

3-colporate pollen grains.

Ectoapertures: colpus, long; edge formed by the muri of the reticulum.

Endoapertures: lalongate colpus; costae faint or sometimes absent.

Ornamentation: reticulate with simplicolumellate muri and rather large lumina.

Exine: sexine/nexine ratio circa 1; sexine consisting of more or less rounded capita supported by short and thin columellae.

Measurements: $\mathrm{P} / \mathrm{E}$ ratio varying from suberect to subtransverse.

All these features have to be considered primitive in comparison to those of recent pollen grains.

From the same locality in which Alangiopollis eocaenicus is found, although in younger assemblages, another fossil, $A$. barghoornianus (TRAVERSE) KrUTzSCH is known. This fossil shows the following features:

3-colporate pollen grains.

Ectoapertures: colpus, length varying from long to middle; colpus edge formed by the muri of the structure pattern or by an unthickened margo.

Endoapertures: lalongate colpus; costae faint.

Ornamentation: reticulate, rugulate or striate with simplicolumellate muri and lumina varying in size.

Exine: Sexine/nexine ratio larger than 1; sexine consisting of capita elongate longitudinally; supported by short and thin columellae.

Measurements: $\mathrm{P} / \mathrm{E}$ ratio transverse.

Fossil Alangium grains are also known from Miocene deposits in India, viz., Margocolporites dubius RamanuJAm and $M$. complexus Ramanujam. These grains show the following features:

3-colporate pollen grains. 
Ectoapertures: colpus, length varying from long to middle; colpus edge formed by a thickened margo.

Endoapertures: lolongate porus, costae faint.

Ornamentation: reticulate with simplicolumellate muri and lumina varying in size.

Exine: sexine/nexine ratio equal to 1 or smaller than 1; sexine consisting of more or less rounded capita supported by short and thin columellae.

Measurements: $\mathrm{P} / \mathrm{E}$ ratio transverse.

It is stated here that the characteristics of Alangiopollis eocaenicus might be considered primitive in comparison to the characteristics of $A$. barghoornianus, Margocolporites dubius, M. complexus and those of recent pollen grains of Alangium. Comparison of all these characters produces some information about the evolutionary trends in the characters. One thing should be kept in mind, however; that these evolutionary trends only refer to the pollen grains of the genus Alangium.

\section{Number of apertures}

The fossil pollen grains are all 3-zonoaperturate; this is, consequently, a primitive feature. All the other numbers of apertures are advanced. The same applies to pantoaperturate. It is easy to recognize that an increase of the number of apertures must be considered advanced, but a difficulty arises when the number of apertures decreases. This decrease can be considered an atavism, if one is of the opinion that 3-aperturate is advanced in comparison to 2- and 1-aperturate (Kuprianova, 1967, 1969; Nair, 1966). There is, however, another possibility. If one studies a 2-aperturate pollen grain it appears that the apertures are situated opposite each other. It is possible to have in mind two imaginary apertures between the two existing ones. By doing so, a quite normal 4-aperturate pollen grain comes out. Thus the explanation for the occurrence of 2-aperturate grains could be, that the genetic blue-print dictated a 4-aperturate pollen grain, but that one barrier or another during development gave rise to a 2-aperturate pollen grain. In my opinion the latter explanation is more acceptable than the former one.

\section{Ectoapertures}

All fossil pollen grains have colpi, which are long in Alangiopollis eocaenicus and somewhat shorter in $A$. barghoornianus. From these data it can be concluded that the shorter the length of the colpus, the more advanced this feature is. As a porus is supposed to be nothing else but a short colpus of which the length/breadth ratio is smaller than 2 (ReirsmA, 1970), it can be postulated that a porus is advanced in comparison to a colpus. This is the more so as pollen grains of the Alangium salviifolium type and the $A$. chinense type $\mathrm{C}$ show a decrease in length 
of the ectocolpus and the transition from an ectocolpus to an ectoporus (Plate XXVII and V). In some pollen grains of the former type the decrease of the polar axis of the ectoporus continues to such an extent that the ectoaperture is no longer visible (Plate XXVII, E and F). This must be considered a final stage of the evolutionary trend, which begins with a long ectocolpus.

The edge of the ectocolpi of pollen grains of Alangiopollis eocaenicus is formed by muri of the structure pattern. In pollen grains of $A$. barghoornianus the edge is sometimes formed by muri of the structure pattern or by an unthickened margo. Since in pollen grains of the Alangium griffithii type and the $A$. griseolloides type transitions are found between an unthickened margo and a thickened margo and in pollen grains of Margocolporites dubius and $M$. complexus a thickened margo occurs, it seems quite reasonable that an evolutionary trend is present between the three features: $(I)$ colpus edge formed by the muri of the structure pattern, (2) colpus bordered by an unthickened margo and (3) colpus bordered by a thickened margo.

\section{Endoapertures}

The endoaperture in pollen grains of Alangiopollis eocaenicus and A. barghoornianus is a lalongate colpus. The endoaperture in pollen grains of Margocolporites dubius and $M$. complexus appears to be a lolongate porus. In fossil Alangium grains no transitions are found between these two features. Since in the pollen grains of a single flower of Alangium javanicum transitions are found between a lalongate endocolpus and a lolongate endoporus, it is tempting to consider the series: (I) lalongate endocolpus, (2) lalongate endoporus, (3) circular endoporus and (4) lolongate endoporus, as an evolutionary trend.

The edge of the endoaperture of pollen grains of Alangiopollis eocaenicus is formed by the nexine, which is sometimes slightly thickened (faint costae), while in pollen grains of $A$. barghoornianus the costae are always faint. Consequently a transition exists between an unthickened edge and a thickened edge. Since in recent pollen grains thick costae are found together with faint costae, it seems logical to suppose that the features: $(I)$ unthickened edge (no costae), (2) faint costae and (3) thick costae form an evolutionary trend.

One of the features which is present in recent pollen grains but not in fossil ones is a thinning of the nexine around the endoaperture and its costae. For this reason it is difficult to draft an evolutionary trend. In pollen grains of the Alangium javanicum type transitions exist between an indistinct thinning of the nexine and a distinct one. This forms, by definition, a morphological series, although I am quite sure that the evolutionary succession runs from an indistinct thinning to a distinct one. 


\section{Ornamentation}

All fossil pollen grains show a simple structure pattern. Because in pollen grains of the Alangium kurzii type transitions exist between a simple structure pattern and a double one and in the pollen grains of the $A$. platanifolium type only a double structure pattern is present, it seems rational to accept these transitions as an evolutionary trend.

The pollen grains of Alangiopollis eocaenicus have a reticulate pattern, while those of $A$. barghoornianus mostly show the same pattern with a tendency to show a rugulate or striate pattern. Thus, a reticulate pattern is primitive while rugulate and striate patterns are advanced. It is difficult to state whether striate is advanced in comparison to rugulate or rugulate is advanced in comparison to striate. Another possibility is that these two patterns have been derived both from a reticulate pattern.

The muri of the structure patterns in all fossil pollen grains are simplicolumellate. From the occurrence of dupli- and pluricolumellate muri together with simplicolumellate ones (Alangium javanicum type, $A$. chinense type A), it can be deduced that the following features: (I) simplicolumellate, (2) duplicolumellate and (3) pluricolumellate form an evolutionary trend.

It is difficult to derive the warty elements of the pollen grains of the $A$. salviifolium type and the $A$. villosum type from the primitive reticulate pattern. A possibility is that these warty elements should be evolved from the pluricolumellate rugulate patterns, if the small connections between the large dots of muri fade away (see for instance Plate XXI, A).

Exine

The sexine/nexine ratio of the pollen grains of Alangiopollis eocaenicus is about 1 and that of the pollen grains of $A$. barghoornianus larger than 1 . Since in recent pollen grains also a sexine/nexine ratio smaller than 1 is found, it seems quite certain that a sexine/nexine ratio of about 1 is primitive, and that both a sexine/nexine ratio larger than 1 and a ratio smaller than 1 are advanced, and that both features are evolved from a sexine/nexine ratio of about 1.

The capita of the pollen grains of Alangiopollis eocaenicus are more or less rounded, while those of the pollen grains of $A$. barghoornianus are elongate longitudinally. These features can be considered as a distinct evolutionary trend.

The columellae of all fossil pollen grains are short and thin. Because in recent pollen grains (Alangium javanicum type, A. griseolloides type) thick columellae occur besides thin ones, it seems reasonable to consider thick columellae to be advanced in comparison to thin columellae. 
The $\mathrm{P} / \mathrm{E}$ ratio of the pollen grains of Alangiopollis eocaenicus varies from suberect to subtransverse, while the other fossil pollen grains and all recent pollen grains have a $\mathrm{P} / \mathrm{E}$ ratio varying from subtransverse to transverse. It seems logical to consider suberect a primitive feature in comparison to all other $\mathrm{P} / \mathrm{E}$ ratio's.

If we compare the above mentioned evolutionary trends with those framed by PunT (1967) for Phyllanthus (Euphorbiaceae), it appears that they agree very well with each other. It seems that the above mentioned trends occur also in other pollen grains of the Dicotyledonae.

\section{EVOLUTIONARY RELATIONSHIPS}

If we look at the features of the recent pollen grains it appears that these pollen grains show a mixture of primitive and advanced features. The pollen grains of the Alangium chinense type A show the largest number of primitive features among the recent grains of Alangium. For this reason the pollen grains of this type should be considered the most primitive of the recent pollen grains. Thus the most primitive pollen grains are found in the section Marlea. This is in accordance with the palaeobotanical data, for all fossil remains of the Lower Tertiary known up till now belong to this section. However, not all specimens of Alangium chinense show primitive pollen grains. It is obvious that the pollen grains of the $A$. chinense types $\mathrm{C}$ and $\mathrm{D}$ are advanced in comparison to the pollen grains of type $\mathrm{A}$, and that the pollen grains of type $\mathrm{C}$ and type $\mathrm{D}$ can be compared with the pollen grains of the $A$. salviifolium type and the $A$. javanicum type respectively, or, in other words, with species belonging to the sections Alangium and Conostigma, but not with species belonging to the section Marlea. Thus it appears that all the possible variations of the characters in the pollen grains of the

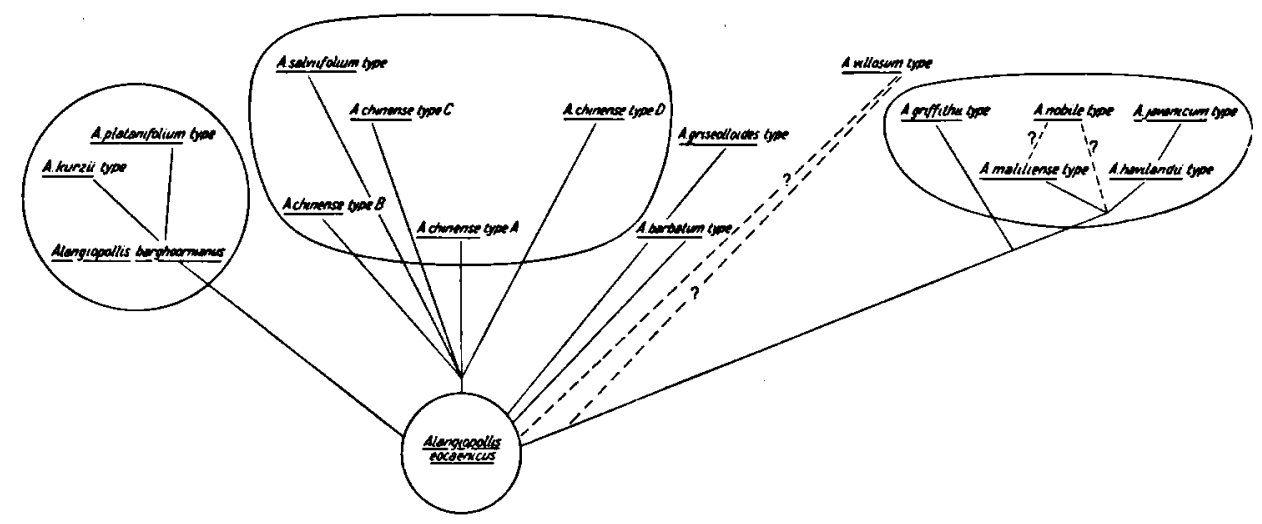

Fig.9. Evolutionary relationships in Alangium on the basis of pollen grains. 
genus Alangium are also found in the pollen grains of a single species, $A$. chinense. For this reason it is attractive to suppose that the recent pollen grains had the same origin, viz., Alangiopollis eocaenicus. Fig.9 illustrates my opinion concerning the evolutionary relationships of the pollen types in Alangium.

The evolutionary relationships in Alangium as developed above do not correspond at all to the opinion of EYDE (1968). His view is based on anatomical and pollen-morphological data. It is a pity that Eyde did not study the pollen grains himself, but that he gathered the results through literature, and they appear to be incomplete. Even in a later study on the pollen grains of Alangium (EYDE et al., 1969) he did not alter his opinion on the evolutionary relationships, although he corrected the wrong data gathered from literature. EYDE (1968) assumed a direct derivation of section Alangium from section Conostigma and a close common ancestry of the sections Rhytidandra and Marlea. He considered the section Marlea a final stage. Some objections can be made against his opinion on the basis of the present results:

(I) It is not possible to define the four sections of Alangium on the basis of the pollen morphology. The sections $R$ hytidandra and Alangium both form a pollenmorphological unit, but the two remaining sections fall apart in several groups of species and in solitary species. Thus it is not possible to consider the sections natural units.

(2) Nearly all Alangium fossils are referable to the section Marlea. For this reason the section Marlea, or at least some species of this section, have to be considered a primitive and not a final stage.

(3) A direct derivation of the section Alangium from the section Conostigma is not obvious, since the pollen grains of both sections are advanced in different directions.

EYDE (1968) based his views also on anatomical features and, although I am not familiar with anatomical features, I am quite sure that these data do not contradict the evolutionary relationships outlined above.

The present pollen-morphological results do not agree with those of YERAMYAN $(1967,1968)$ and they are certainly not in favour of a reinstatement of the genus Marlea RoxB..

\section{PHYTOGEOGRAPHY}

The present distribution of plants cannot be understood without the knowledge of the distribution in the past. Without this knowledge the statement of HutCHINSON (1959) that: "the distribution of the distinctive genus Alangium, the sole member of the family Alangiaceae, suggests that it spread across the Old World after America was separated" is understandable, although the fossil data are not exactly in favour of this statement (cf. Fig.10).

It is difficult to understand the distribution in the past, because data are few 


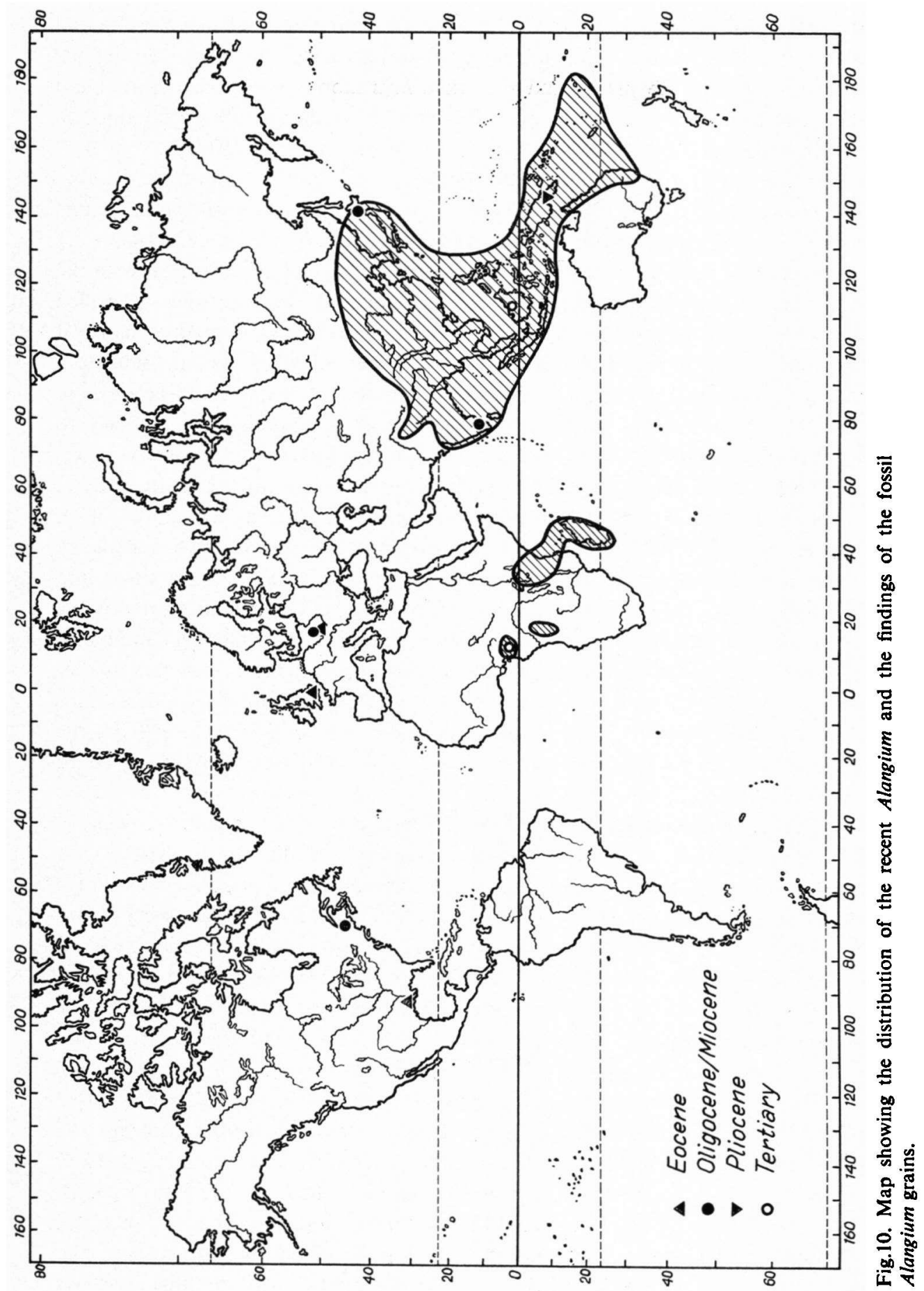


and mostly incomplete. Add to this the poor knowledge of palaeogeography and palaeoclimatology, and it will be clear that no agreement exists concerning the places of origin of the plants and the trackways along which the plants could migrate. It would, therefore, be very valuable if more data could be obtained in order to solve the problems concerning places of origin and trackways.

It seems possible that pollen morphology can contribute its mite towards solving these problems. As mentioned before the characteristics of the pollen grains can evolve from primitive to advanced in the course of time (see p. 282). It appears that series of transitions occur in recent pollen grains which are identical with the evolutionary trends. If the possibility is accepted that characteristics of pollen grains can evolve during the migration of a plant, then a geographical series of transitions of one or more characteristics in recent pollen grains can indicate a trackway along which the plant could have migrated. In most cases these series of transitions are not clear, so that the assistance of taxonomists is necessary to solve these problems. However, in some cases the geographical series of transitions are so clear that it may be justifiable to draw some conclusions from these data.

Such a clear series of transitions can be seen in the pollen grains of $A$. chinense. Although no taxonomist is apt to split this species into subspecies or even into geographical varieties, the pollen grains can still be classified into four types, which are geographically restricted (Fig.1). The pollen grains of the $A$. chinense type $\mathrm{A}$ have a sexine/nexine ratio which is larger than 1 in India and the western part of the Asiatic mainland and a sexine/nexine ratio which is smaller than 1 in the eastern part of the Asiatic mainland (see p. 260). The pollen grains of the $A$. chinense type $\mathrm{D}$ show an increase in the number of apertures from the Philippine Islands to Java (see p. 264). The A. chinense type B is restricted to India and the $A$. chinense type $\mathrm{C}$ to Africa.

The $A$. chinense type $\mathrm{A}$ is the most primitive type of the four $A$. chinense types (see p. 287) and is found in Miocene deposits in India (see p. 282).

From these data it could be concluded that $A$. chinense originated elsewhere in India and migrated to Africa either via the Lemurian land bridge (see FloRIN, 1963; VAN STEENIS, 1962) or via western Asia. The present land connection between Asia and Africa was originally much broader, so that a detailed trackway cannot be given. The migration to the east must have been taken place via the Asiatic mainland, Taiwan, the Philippine Islands, the Moluccas and the Lesser Sunda Islands to Java (cf VAN SteENIS, 1934, 1935; MulLer, 1966).

The pollen grains of $A$. javanicum have ectocolpi which vary in length (see p. 272). This feature indicates that one trackway could have existed from the Solomon Islands via Celebes to the Philippine Islands and another trackway from northwestern Borneo via Java and Sumatra to Malaya (cf. Van SteENIS, 1934, 1935). These two trackways could be explained by the fact that the ancestral $A$. javanicum was originally found in a region bounded by Borneo and the Solomon Islands at the least and that, for reasons unknown to me, this area was 
restricted to the Solomon Islands and northwestern Borneo. Afterwards a remigration of A. javanicum took place from these two territories.

The trackways of the other species of Alangium cannot be deduced from the characteristics of the pollen grains alone.

\section{PLACE OF ALANGIACEAE IN THE GENERAL SYSTEM}

Nearly all taxonomists classify Alangiaceae near Cornaceae, so it is an obvious step to compare the pollen grains in both families. It appears that the grains have not much in common. The only feature in common is the thinning of the nexine around the endoaperture and its costae, which is found in grains of Curtisia and Cornus (personal observation). The same thinning is found in grains of Garryaceae (personal observation), Davidiaceae and Nyssaceae (SoHMA, 1963, 1967; personal observation) and also in some families belonging to the Celastrales (VAN Campo and Hallé, 1960; Ding Hou, 1969; Lobreau, 1969), but not in Araliaceae and Apiaceae (Umbelliferae). Thus, there are indications on the basis of pollen morphology that the Araliaceae and Apiaceae do not belong to the order in which Cornaceae, Alangiaceae, Nyssaceae and Davidiaceae are placed (see MEEUwSE, 1970). These results agree with the opinion of BENSON (1957), who placed these families in the order Cornales. The relationship between the Cornales and Celastrales as suggested by Lanjouw et al. (1968) is confirmed by the pollen-morphological results. However, it is possible that the occurrence of a thinning of the nexine around the endoaperture in pollen grains of the Cornales and of the Celastrales is convergent, which is the case with other taxonomic features common to both orders (see ENGLER, 1964). Further investigation is necessary to solve this problem.

\section{ACKNOWLEDGEMENTS}

The author wishes to express his deep gratitude to Prof. Dr. F. P. Jonker, under whose supervision this work was carried out. He is also very grateful to Drs. W. Punt and H. Visscher, who offered fruitful discussions and kindly criticized the manuscript. Sincere thanks are due to Dr. M. M. A. Sassen of the Catholic University of Nijmegen for his permission to use the electron transmission microscope, and to Mr. U. Theis of the Cambridge Instrument Company, Dortmund, Germany, for his assistance with the electron scanning microscope. Credit is due to Mr. H. E. Elsendoorn for printing the light-microscopical and electrontransmission-microscopical photomicrographs, to Mr. A. Kuiper for printing the electron-scanning-microscopical photomicrographs, to Mr. T. Schipper for the drawings and to Miss H. C. Reitsma for typing the manuscript. 


\section{REFERENCES}

AwASTHi, N., 1968. A new fossil wood belonging to the family Alangiaceae from the Tertiary of south India. Palaeobotanist, 17(3): 322-325.

Benson, L., 1957. Plant Classification. Heath and Co, Boston, 688 pp.

Bloembergen, S., 1939. A revision of the genus Alangium. Bull. Jardin Botan. Buitenzorg, Sér. 3, 16: 139-235.

Capuron, R., 1962. Contribution a l'étude de la flore forestière de Madagascar, 7. Présence à Madagascar du genre Alangium et description d'une espèce nouvelle. Adansonia, 2: 282-284.

Chandler, M. E. J., 1961. The Lower Tertiary Floras of southern England, 1. Paleocene Floras, London Clay Flora (supplement). British Museum (Natural History), London, 354 pp.

Chander, M. E. J., 1964. The Lower Tertiary Floras of Southern England, 4. A Summary and Survey of Findings in the Light of Recent Observations. British Museum (Natural History), London, $151 \mathrm{pp}$.

Снао, Сн.-Y., 1954. Comparative pollen morphology of the Cornaceae and allies. Taiwania, 5: 93-106.

Cookson, I. C., 1957. On some Australian Tertiary spores and pollen grains that extend the geological and geographical distribution of living genera. Proc. Roy. Soc. Victoria, 69: 41-54.

Davis, P. H. and Heywood, V. H., 1963. Principles of Angiosperm Taxonomy. Oliver and Boyd, Edinburgh-London, $556 \mathrm{pp}$.

Ding Hou, 1969. Pollen of Sarawakodendron (Celastraceae) and some related genera, with notes on techniques. Blumea, 17: 97-120.

Engler, A., 1964. Syllabus der Pflanzenfamilien, 2. Angiospermen, 12. Aufl., Bornträger, Berlin. $666 \mathrm{pp}$.

Erdtman, G., 1948. Palynology. Aspects and prospects. Svensk Botan. Tidskr., 42(4): 467-483.

Erdtman, G., 1952. Pollen Morphology and Plant Taxonomy, 1. Angiosperms. Almqvist and Wicksell, Stockholm, 539 pp.

EYDE, R. H., 1968. Flowers, fruits and phylogeny of Alangiaceae. J. Arnold Arboretum (Harvard Univ.), 49(2): 168-192.

Eyde, R. H., Bartlett, A. and BARghoORn, E. S., 1969. Fossil record of Alangium. Bull. Torrey Botan. Club, 96(3): 288-314.

FaIRChLd, W. F. and Elsik, W. C., 1969. Characteristic palynomorphs of the Lower Tertiary in the Gulf Coast. Palaeontographica, $B, 128: 81-89$.

Florin, R., 1963. The distribution of conifer and taxad genera in time and space. Acta Hort. Berg., 20(4): 1-312.

Grvulesco, R., 1970. Observations nouvelles sur Byttneriophyllum tiliaefolium (AL. BRAUN) KNobloch et KVAČ́EK. Rev. Palaeobotan. Palynol., 10(3): 233-242.

Hutchinson, J., 1959. The Families of Flowering Plants, 1. Dicotyledones, 2 ed., Clarendon Press, Oxford, $368 \mathrm{pp}$.

International Code of Botanical NomenClature, 1966. Regnum Vegetabile, 46: 402 pp.

KirCHHEImer, F,, 1936. Beiträge zur Kenntnis der Tertiärflora, Früchte und Samen aus dem deutschen Tertiär. Palaeontographica, B, 82: 73-141.

Krutzsch, W., 1962. Stratigraphisch bzw. botanisch wichtige neue Sporen- und Pollenformen aus dem deutschen Tertiär. Geologie (Berlin), 11: 265-307.

KRUTzsch, W., 1969. Über einige stratigraphisch wichtige neue longaxoner Pollen aus dem mitteleuropäischen Alttertiär. Geologie (Berlin), 18(4): 472-487.

Kuprianova, L. A., 1967. Apertures of pollen grains and their evolution in angiosperms. Rev. Palaeobotan. Palynol., 3(1/4): 73-80.

Kuprianova, L. A., 1969. On the evolutionary levels in the morphology of pollen grains and spores. Pollen Spores, 11(2): 333-351.

Lanjouw, J. (Editor), 1968. Compendium van de Pteridophyta en Spermatophyta. Oosthoek, Utrecht, 342 pp.

Lobreau, D., 1969. Les limites de l'ordre des Celastrales d'après le pollen. Pollen Spores, 11(3): 499-555. 
Mchedlishyili, N. D. and Samoilovich, S. R., 1962. Common elements in the Mesozoic and Cenozoic floras of western Siberia and Australia. In: A. N. Sladkov (Editor), Reports of Soviet Palynologists for the First International Conference on Palynology (Tucson, 1962). Publishing House of the U.S.S.R. Academy of Sciences, Moscow, pp. 94-104 (in Russian).

MeEuwse, A. D. J., 1970. The descent of the flowering plants in the light of new evidences from phytochemistry and from other sources, 2. Suggestions for a holotaxonomic major classification. Acta Botan. Neerl., 19(2): 133-140.

Mikı, S., 1956. Endocarp remains of Alangiaceae, Cornaceae and Nyssaceae in Japan. J. Inst. Polytech., Osaka City Univ., Ser. D, 7: 275-297.

Miki, S. and Kokawa, S., 1962. Late Cenozoic floras of Kyushu, Japan. J. Inst. Polytech., Osaka City Univ., Ser. D, 13: 65-85.

MUlleR, J., 1964. Palynological contributions to the history of Tertiary vegetation in NW. Borneo. Intern. Botan. Congr., 10th, Edinburgh, 1964, Abstr., p.271.

MUller, J., 1966. Montane pollen from the Tertiary of NW. Borneo. Blumea 14: 231-235.

NAIR, P. K. K., 1966. Trends in the morphological evolution of pollen and spores. J. Indian Botan. Soc., 64: 468-478.

NAGY, E., 1962. New pollen species from the Lower Miocene of the Bakony Mountain. Acta Botan. Acad. Sci. Hung., 8: 153-163.

Pacltova, B., 1963. Die palynologische Forschung in den Schichten Chatt-Aquitan in Braunkohlenbecken Modry Kamen. Geol. Práce Zpravy, 27: 121-123 (in Czech).

Pacltova, B., 1966. The results of micropalaeobotanical studies of the Chattian-Aquitanian complex in Slovakia. Rozpravy Cesk. Akad. Ved, Rada Mat. Prirod. Ved, 76(13): 1-68.

Punt, W., 1967. Pollen morphology of the genus Phyllanthus (Euphorbiaceae). Rev. Palaeobotan. Palynol., 3(1/4): 141-150.

Punt, W. and Leenhouts, P. W., 1967. Pollen morphology and taxonomy in the Loganiaceae. Grana Palynologica, 7: 469-516.

PURI, G. S., 1964. Some palynological studies on the past vegetation of Nigeria. Intern. Botan. Congr., 10th. Edinburgh, 1964, Abstr., p.451.

Ramanujam, C. G. K., 1966. Palynology of the Miocene lignite from South Arcot District, Madras, India. Pollen Spores, 8(1): 149-203.

ReIrsma, TJ., 1969. Size modification of recent pollen grains under different treatment. Rev. Palaeobotan. Palynol., 9(3/4): 175-202.

Rertsma, TJ., 1970. Suggestions towards unification of descriptive terminology of angiosperm pollen grains. Rev. Palaeobotan. Palynol., 10(1): 37-60.

Rowley, J. R., 1959. The fine structure of the pollen wall in the Commelinaceae. Grana Palynologica, 2: 3-31.

SAto, S., 1963. Palynological study on Miocene sediments of Hokkaido, Japan. J. Fac. Sci., Hokkaido Univ., Ser. 4, 12: 1-93.

SeIN, M. K., 1961. Fossil Spores of the London Clay. Thesis, Univ. London.

Soнma, K., 1963. Pollen morphology of the Nyssaceae, 1. Nyssa and Camptotheca. Sci. Rep. Tohoku Univ., Fourth Ser., 29: 389-392.

Sohma, K., 1967. Pollen morphology of the Nyssaceae, 2. Nyssa and Davidia. Sci. Rep. Tohoku Univ., Fourth Ser., 33: 527-532.

Straka, H. et Simon, A., 1967. Palynologie Madagassica et Mascarenica, fam. 158 bis, Alangiaceae. Pollen Spores, 9(3): 442-446.

Traverse, A., 1955. Pollen analysis of the Brandon Lignite of Vermont. U.S., Bur. Mines, Rept. Invest., $1551,107 \mathrm{pp}$.

Tsukada, M., 1963. Pollen morphology and identification, 1. Eucaesalpinieae. Pollen Spores, 5(2): 239-284.

Van Campo, M. et Hallé, N., 1959. Le pollen des Hippocrateaceae d'Afrique de l'ouest. Palynologie africaine, 3. Bull. Inst. Franç. Afrique Noire, Sér. A 3 (Sénégal), 21: 807-899.

VAN SteEnis, C. G. G. J., 1934. On the origin of the Malaysian mountain flora, 1. Bull. Jardin Botan. Buitenzorg, Sér. 3, 13: 135-262.

VAN SteEnis, C. G. G. J., 1935. On the origin of the Malaysian mountain flora, 2. Bull. Jardin Botan. Buitenzorg, Sér. 3, 13: 289-417.

Van Steenis, C. G. G. J., 1962. The land-bridge theory in botany. Blumea, 11: 235-372.

Rev. Palaeobotan. Palynol., 10 (1970) 249-332 
Yeramyan, E. N., 1967. The types of sporoderm of microspores in the representatives of the order Cornales and their genetic affinities. Botan. Zh., 52(9): 1287-1294 (in Russian).

Yeramyan, E. N., 1958. The palynomorphology of the genus Alangium LaM. in connection with the phylogeny, Akad. Nauk Armjansk. S.S.R., Biol. Zh., 21(1): 85-92 (in Russian).

\section{EXPLANATIONS OF PLATES}

PLATE I (p.300)

A. chinense, Tso 21110 , Kwangtung; scanning micrographs.

A. Polar view; $\times 680$.

B. Equatorial view; $\times 680$.

C. Detail of $B ; \times 2700$.

\section{PLATE II (p.301)}
A. chinense
A. Rock 16125 , Szechwan; equatorial view, compound aperture; $\times 655$.
B. Merrill and Swingle 11359, Nanking; polar view, optical section; $\times 655$.
C. Cheo and Steward 706, Kwangsi; apo- and mesocolpium; $\times 896$.
D. Wilson 1134, Hupeh; colpus end; $\times 896$.
E-G. Steqard and Cheo 706, Kwangsi; structure pattern from high to low focus; $\times 896$.
H. Tso 21110, Kwangtung; section of the sexine; $\times 4,000$.
J. Steward and Cheo 706 , Kwangsi; optical section of the exine; $\times 896$.

\section{PLATE III (p.302)}
A. chinense
A-C. Rock 16125 , Szwechwan; structure pattern from high to low focus; $\times 896$.
D. Koeltz 4771, India; equatorial view, compound aperture; $\times 896$.
E. Steward and Cheo 706, Kwangsi; equatorial view, compound aperture; $\times 655$.
F. Rock 8873, Yunnan; apo- and mesocolpium; $\times 655$.
G. Kerr 1121, Thailand; colpus end; $\times 896$.
H. d'Alleizette s.n., Yunnan; optical section of the exine; $\times 896$.
J. Kerr 1121, Thailand; optical section of the exine; $\times 896$.

\section{PLATE IV (p.303)}

A. chinense; $\times 896$.

A-E. d'Alleizette s.n., Yunnan; structure pattern from high to low focus.

F-H. Prain's coll. s.n., Sikkim; structure pattern from high to low focus.

J-M. d'Alleizette 2971, India.

J-L. Structure pattern from high to low focus.

M. Ectocolpus and structure pattern at high focus.

\section{PLATE V (p.304)}

A. chinense, Zenker 1416, Africa.

A-D. Ectoaperture and thickening of the sexine in equatorial view; $\times 655$.

E. Polar view, optical section; $\times 655$.

F-G. Structure pattern; $\times 896$. 
A. chinense; $\times 896$.

A-D. Zenker 1416, Africa; structure pattern from high to low focus.

E-K. Cenabre 29767, Philippine Islands.

E. Structure pattern at high focus.

F-J. Structure pattern from high to low focus.

K. Optical section of the exine.

\section{PLATE VII (p.306)}

A. kurzii

A-B. Tsiang 2064, Kwangtung; scanning micrographs:

A. Whole grain; $\times 650$.

B. Detail of colpus end and structure pattern; $\times 2,450$.

C-F. Chung and Sun 203, Kiangsi; $\times 896$.

C-F. Structure pattern on the poles from high to low focus.

\section{PLATE VIII (p.307)}

A. kurzii, Tsiang 2064, Kwangtung.

A. Detail of colpus end and structure pattern, scanning micrograph; $\times 2,600$.

B-D. Sections of the exine; $\times 4,000$.

PLATE IX (p.308)

A. kurzii; $\times 655$.

A. Yates 2485, Sumatra; polar view, colpi at focus.

B. Tsang 22181, Kwangsi; polar view, apocolpium at focus.

C. Fan and Li 190, Anhwei; equatorial view, compound aperture.

D. Dahlström 10, Hunan; equatorial view, compound aperture.

E. Lei 513, Hainan; equatorial view, compound aperture.

F. Tsiang 2064, Kwangtung; polar view, apocolpium.

G. Tsiang 20555, Kwangtung; polar view, optical section.

PLATE X (p.309)

A-G A. kurzii; $\times 896$.

A-C. Tsang 2064, Kwangtung; meso- and apocolpium from high to low focus.

D-G. Tsang 20555, Kwangtung; structure pattern from high to low focus.

H-L. A. rotundifolium, Buys 32, Sumatra; structure pattern from high to low focus; $\times 896$.

PLATE XI (p.310)

A. platanifolium, Murata 8849, Japan; scanning mircographs.

A. Hole grain; $\times 600$.

B. Detail of structure pattern; $\times 2,600$.

PLATE XII (p.311)

A. platanifolium

A-B. Oldham 471, Cheju Do; $\times 655$.

A. Polar view, structure pattern.

B. Equatorial view, compound aperture.

C. Murata 8849 , Japan; section of the exine; $\times 4,000$.

D-G. Azuma s.n., Japan; structure pattern from high to low focus; $\times 896$. 
A. barbatum; $\times 896$.

A-B. Clemens 4200 , South Vietnam; equatorial view.

A. Ectocolpus at focus.
B. Endoporus at focus.

C. Garrett 1317, Thailand; equatorial view, compound aperture.

D-I. Sin 9570, Kwangtung.

D. Optical section of the exine.

E-I. Structure pattern from high to low focus.

\section{PLATE XIV (p.313)}

A. barbatum, Garrett 1317, Thailand.

A. Ectocolpus end; $\times 896$.

B-C. Polar view, optical section; $\times 655$.

B. 4-Colporate grain.

C. 3-Colporate grain.

D. Optical section of exine; $\times 896$.

E-I. Structure pattern from high to low focus; $\times 896$.

PLATE XV (p.314)

A. griffithii, $\mathrm{Cel} / \mathrm{V} / 128$, Celebes; scanning micrographs.

A. Whole grain; $\times 1,300$.

B. Detail of structure pattern; $\times 6,500$.

\section{PLATE XVI (p.315)}

A-F. A. griffithii

A. Ambullah 33383, Borneo; equatorial view, compound aperture; $\times 655$

B-E. Cel/V/128, Celebes; structure pattern from high to low focus; $\times 896$.

F. Section of the exine; $\times 4,000$.

G-H. A. scandens, Murthy and Ashton 23361, Borneo.

G. Polar view, optical section; $\times 655$.

H. Optical section of the exine; $\times 896$.

\section{PLATE XVII (p.316)}

A. nobile

A-G. Bequin 582, Sumatra.

A-C. Structure pattern from high to low focus; $\times 896$.

D-F. Structure pattern from high to low focus; $\times 896$.

G. Ectocolpus end and endoaperture; $\times 655$.

H. Griffith 3885, Malaya; optical section of exine; $\times 896$.

\section{PLATE XVIII (p.317)}

A. javanicum, Snijder 4461, Solomon Islands; scanning micrographs.

A. Equatorial view; $\times 610$.

B. Detail of colpus end and structure of $A ; \times 2,400$.

C. Compound aperture and margo; $\times 2,400$. 


\section{A. javanicum; $\times 655$.}

A. Schram 9455, New Guinea; polar view, optical section.

B. Griffith 3383, Malaya; polar view, optical section.

C-D. Maingay 706, Malaya; equatorial view.

C. Ectocolpus.

D. Endoporus and surrounding thinning of the nexine.

E. Edano 3245, Philippine Islands; equatorial view, compound aperture.

F. Mikil 41761, Borneo; equatorial view, end of the ectocolpus.

\section{PLATE XX (p.319)}

\section{A. javanicum; $\times 896$.}

A. Paymans 180, Borneo; equatorial view, colpus end and reticulum.

B-D. Blume 7529, Java; structure pattern from high to low focus.

E-G. Kostermans and Anta 1152, Bangka; structure pattern from high to low focus.

H-K. Kostermans 4365, Borneo; structure pattern from high to low focus.

L-N. Whitmore 768, Solomon Islands; structure pattern from high to low focus.

O-Q. Wood SAN 15084, Borneo; structure pattern from high to low focus.

\section{PLATE XXI (p.320)}

\section{A. javanicum; $\times 896$.}

A-B. Smythies and Ashton 5851, Borneo; structure pattern from high to low focus.

C. Mikil 41761, Borneo; structure pattern.

D-E. Elmer 21165, Borneo; colpus end and structure pattern from high to low focus.

F. Mikil 41761, Borneo; structure pattern.

G-J. Havilland and Hose 2885, Borneo; structure pattern from high to low focus.

K-L. Whitmore 942, Solomon Islands; structure pattern from high to low focus.

\section{PLATE XXII (p.321)}

\section{A. javanicum}

A. Wood SAN 15084, Borneo; optical section of exine; $\times 896$.

B. Schram 9455 , New Guinea; optical section of exine; $\times 896$.

C. Ledermann 9818 , New Guinea; polar view, optical section; $\times 896$.

D-F. Achmad 1266, Sumatra; sections of the exine.

D. Section of the exine; $\times 4,000$.

E. Region of the aperture; $\times 4,000$.

F. Detail of $E ; \times 9,320$.

\section{PLATE XXIII (p.322)}

\section{A. havilandii}

A-B. Sanusi bin Tahir 9218, Borneo; scanning micrographs.
A. Equatorial view; $\times 660$.
B. Detail of aperture of $A ; \times 2,600$.

C-J. Anderson 12868, Borneo; $\times 896$.

C. Ectocolpus end.

D-E. Structure pattern from high to low focus.

F. Optical section of exine.

G-I. Structure pattern from high to low focus. 
PLATE XXIV (p.323)

A. maliliense, $\mathrm{Cel} / \mathrm{V} / 161$, Celebes.

A. Scanning micrograph, polar view; $\times 1,150$.

B. Equatorial view, compound aperture; $\times 655$.

C. Equatorial view, endoporus; $\times 655$.

D-F. Structure pattern from high to low focus; $\times 896$.

G. Optical section of the exine; $\times 896$.

H. Scanning micrograph; $\times 580$.

\section{PLATE XXV (p.324)}

A. griseolloides, Service Forestier de Madagascar 25752 S.F.

A. Polar view, optical section; $\times 896$.

B. Optical section of the exine; $\times 896$.

C. Polar view, apocolpium; $\times 655$.

D. Colpus end; $\times 896$.

E. Equatorial view, compound aperture; $\times 655$.

F. Equatorial view, optical section; $\times 655$.

G. Equatorial view, compound aperture; $\times 655$.

H-L. Structure pattern of the apocolpium from high to low focus; $\times 896$.

\section{PLATE XXVI (p.325)}

\section{A. salviifolium}

A-C. Liang 65366, Hainan.
A. Scanning micrograph, equatorial view; $\times 650$.
B. Scanning micrograph, detail of $A ; \times 2,600$.
C. Section of the exine; $\times 4,000$.

D. Royal F.D. Siam 88, Thailand; polar view, optical section; $\times 655$.

\section{PLATE XXVII (p.326)}

A-B. A. salviifolium; $\times 655$.

A. Royal F.D. Siam 88, Thailand; equatorial view, ectocolpus.

B. Hohenacker 700 , India; equatorial view, compound aperture.

C. A. brachyanthum, Curran 10341, Philippine Islands; equatorial view, compound aperture; $\times 655$.

D-H. A. salviifolium; $\times 655$.

D. Stocks, Law s.n., India; equatorial view, compound aperture.

E. How 71319, Hainan; equatorial view, compound aperture.

F. How 70323, Hainan; equatorial view, simple endoaperture.

G. Bog. Bot. Gard. XVII-C-136; equatorial view, compound aperture.

H. Garrett 1075, Thailand; simple ectoapertures.

\section{PLATE XXVIII (p.327)}

A. salviffolium; A-D.; $\times 655$, E-J; $\times 896$.

A. Teysman 13832, Celebes; compound apertures.

B. Pierre 9197, South Vietnam; ectoaperture with two endoapertures.

C. Pierre 9197, South Vietnam; ectocolpus with three endopori.

D. Bog. Bot. Gard. XVIII-C-136; ectocolpus with two endopori.

E-J. Hohenacker 700, India; structure pattern from high to low focus. 


\section{PLATE XXIX (p.328)}

A. salviifolium; $\times 896$, except $0 ; \times 655$.

A-C. Stocks, Law, s.n., India; structure pattern from high to low focus.

D-F. How 71319, Hainan; structure pattern from high to low focus.

G-K. Stocks, Law s.n., India; structure pattern from high to low focus.

L-N. Wight 1255, India; structure pattern from high to low focus.

O. Zollinger 2289, Java; structure pattern at high focus.

\section{PLATE XXX (p.329)}

A. villosum ssp. vitiense, Degener 15500, Fiji Isl., scanning micrographs.

A. Equatorial view; $\times 1,250$.

B. Detail of $A$, region of endoaperture; $\times 6,250$.

\section{PLATE XXXI (p.330)}

A. villosum; $\times 655$.

A. ssp. bussyanum, McKee 5151, New Caledonia; polar view, optical section.

B. ssp. solomonense, Whitmore 777 , Solomon Islands; polar view, optical section.

C. ssp. polyosmoides, Van Royen and Sleumer 8126, New Guinea; polar view, optical section.

D. ssp. polyosmoides, Brass 20308, Australia; polar view, optical section.

E-F. ssp. bussyanum, McKee 5151, New Caledonia; equatorial view.

E. Ectocolpus at focus.

F. Endoporus at focus.

\section{PLATE XXXII (p.331)}

A. villosum

A-B. ssp. polyosmoides, Van Royen and Sleumer 8126, New Guinea; equatorial view; $\times 655$.

A. Ectocolpus at focus.

B. Endoporus at focus.

C. Ssp. ferrugineum, Brass 22698 , New Guinea; polar view, structure pattern; $\times 655$.

D. ssp. polyosmoides, Van Royen and Sleumer 8126, New Guinea; polar view, structure pattern; $\times 655$.

E. $\quad$ ssp. bussyanum, McKee 5151, New Caledonia; exine, optical section; $\times 896$.

F. ssp. vitiense, Degener 15500 , Fiji Islands; section of the nexine; $\times 4,000$.

\section{PLATE XXXIII (p.332)}

Alangiopollis eocaenicus, London Clay, Eocene. White Cliff Bay I.O.W., coll. J. Pallot, slide number B.M. (N.H.) V.44355; $\times 896$.

A. Polar view.

B-D. Optical section of the exine.

E-H. Structure pattern from high to low focus. 


\section{PLATE I}
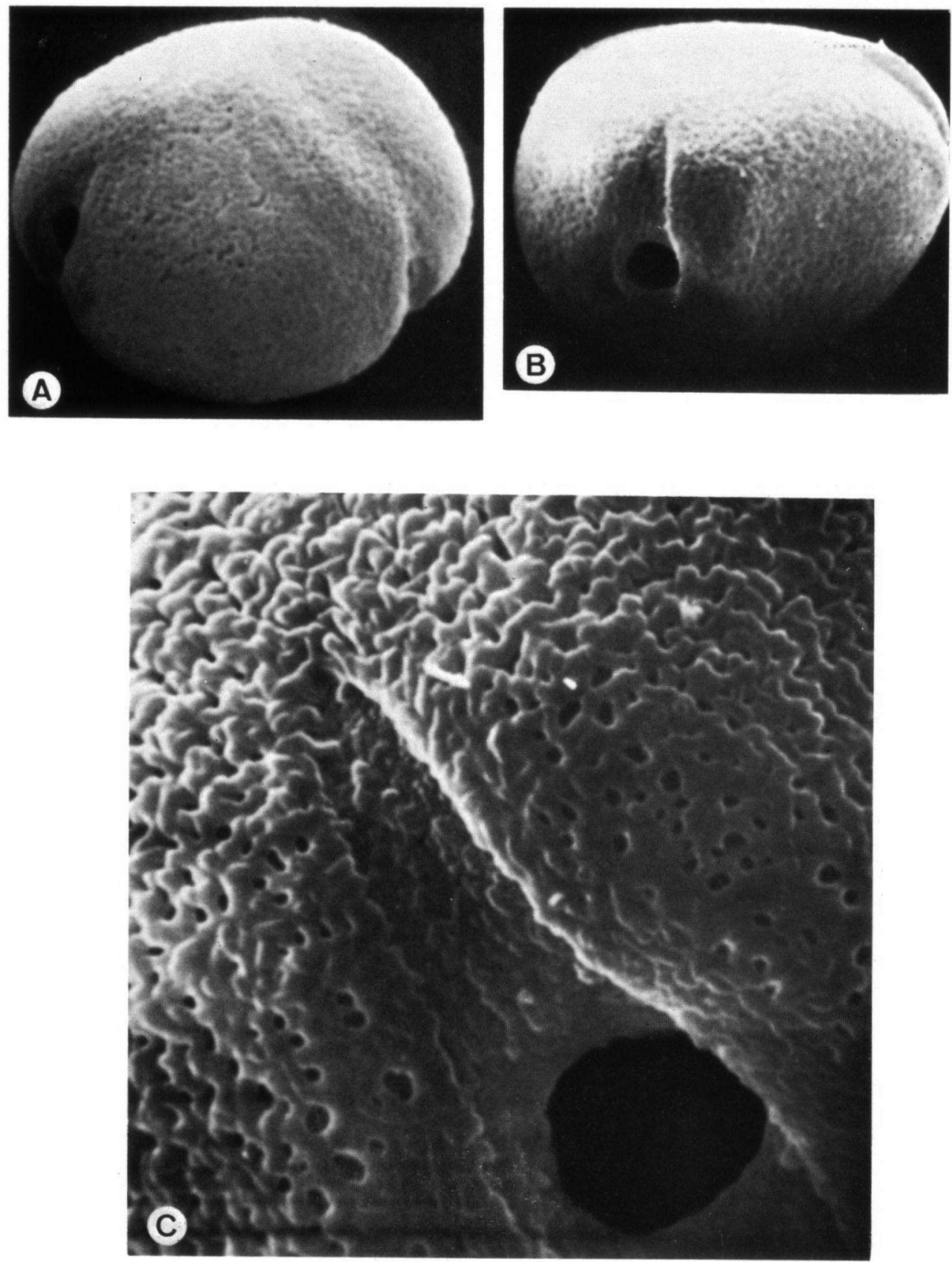
PLATE II
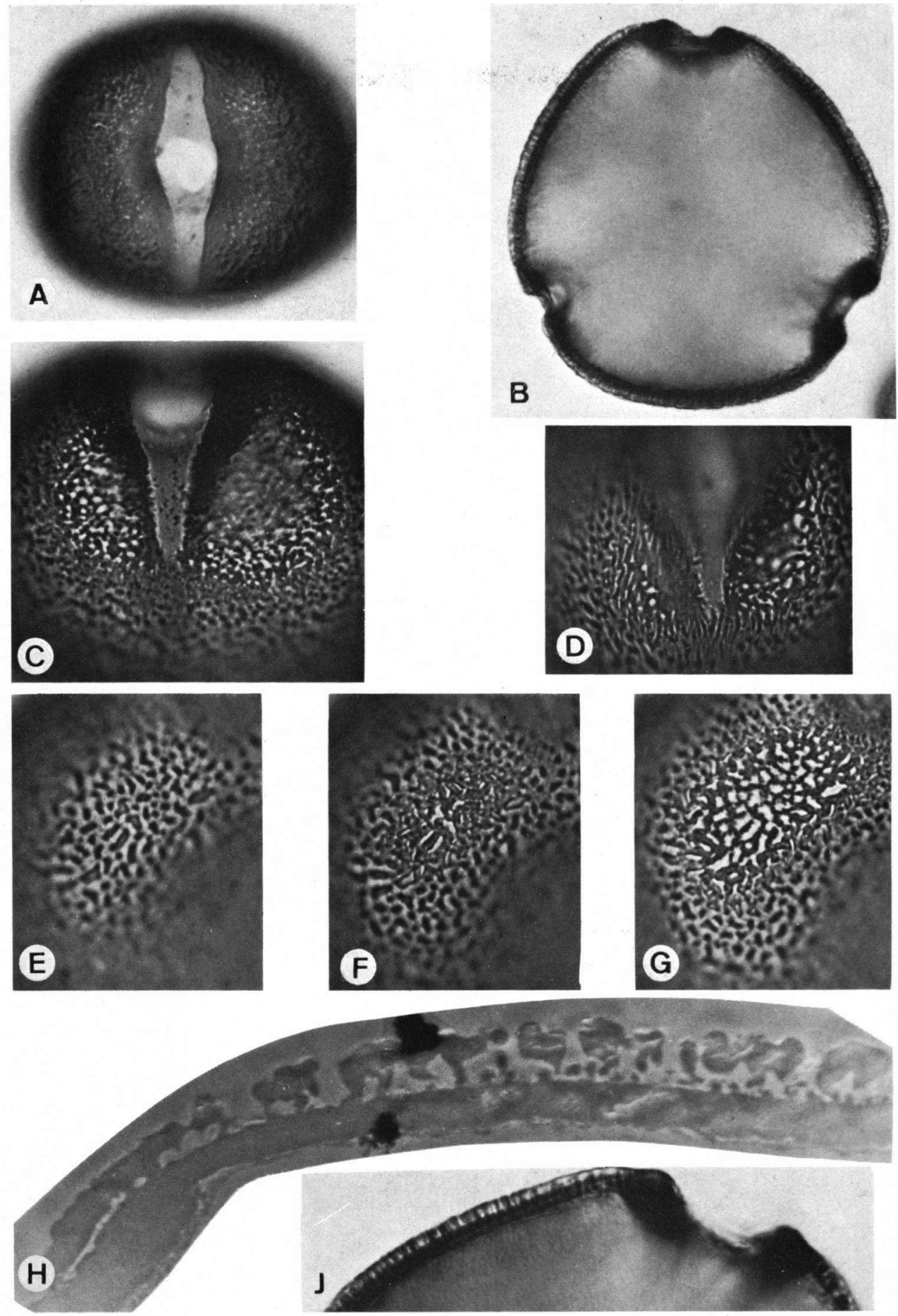

Rev. Palaeobotan. Palynol., 10 (1970) 249-332 
PLATE III
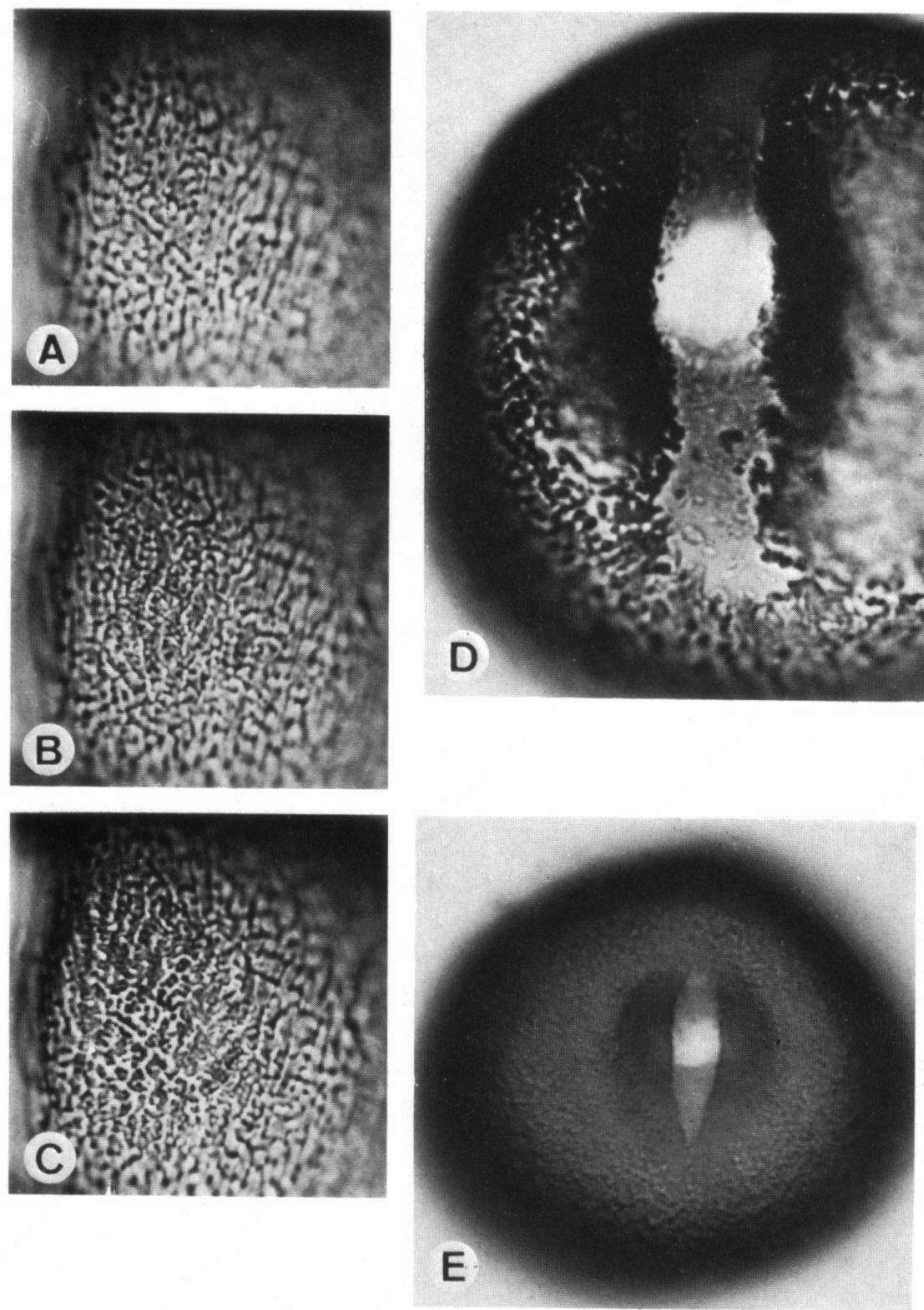
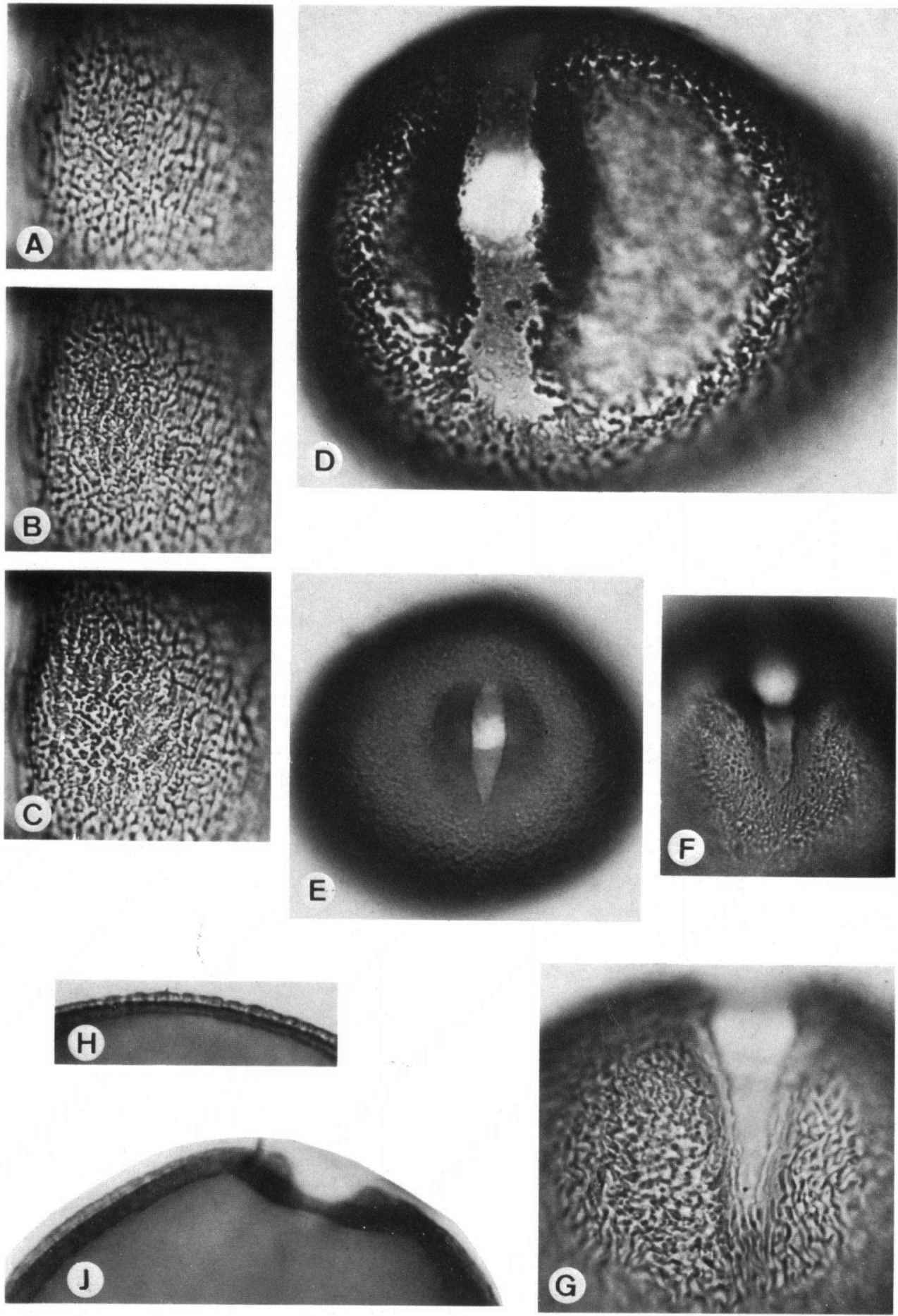
PLATE IV

(A)
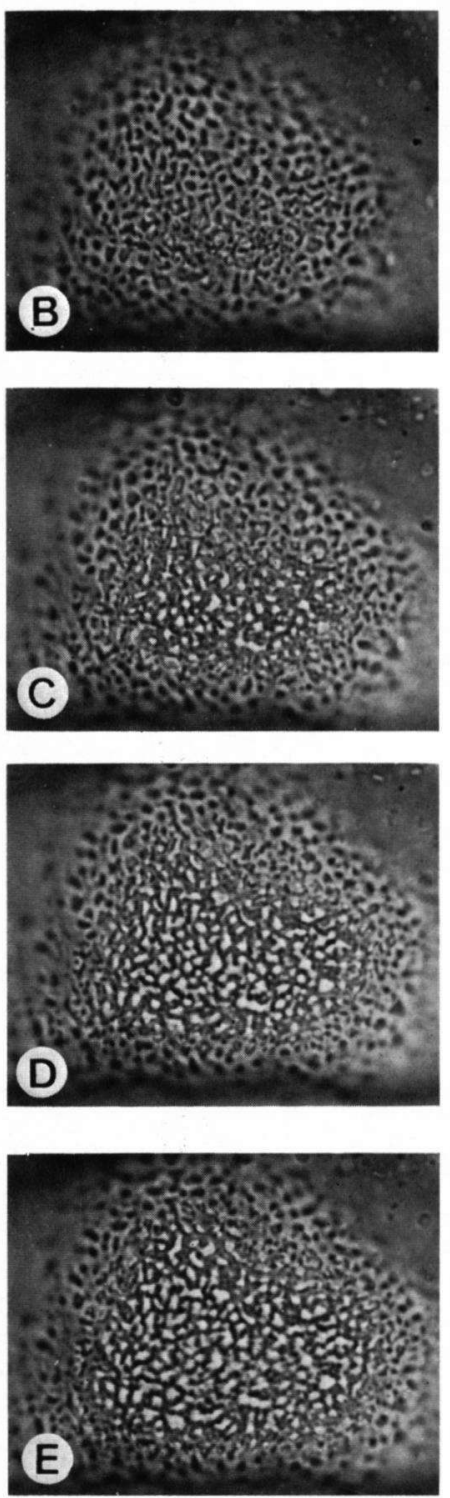
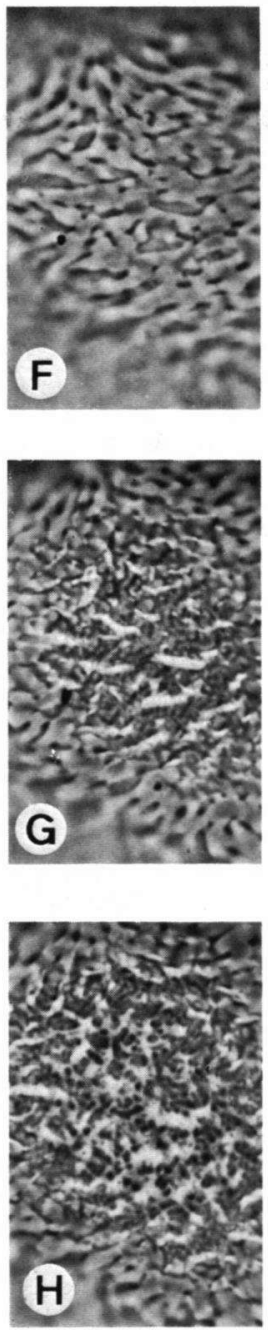
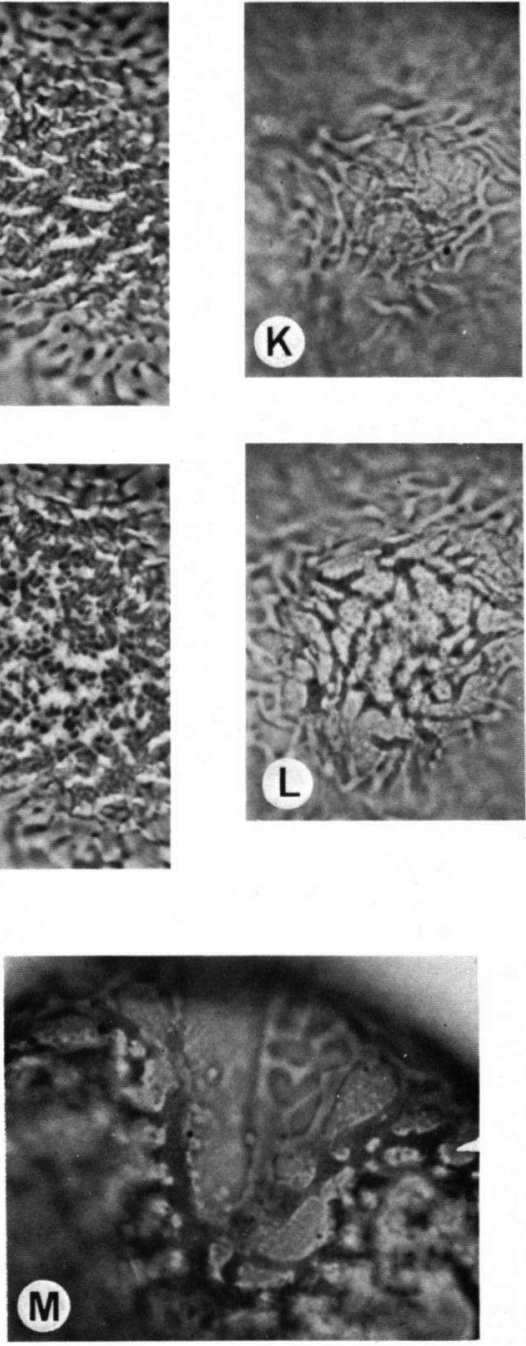


\section{PLATE V}
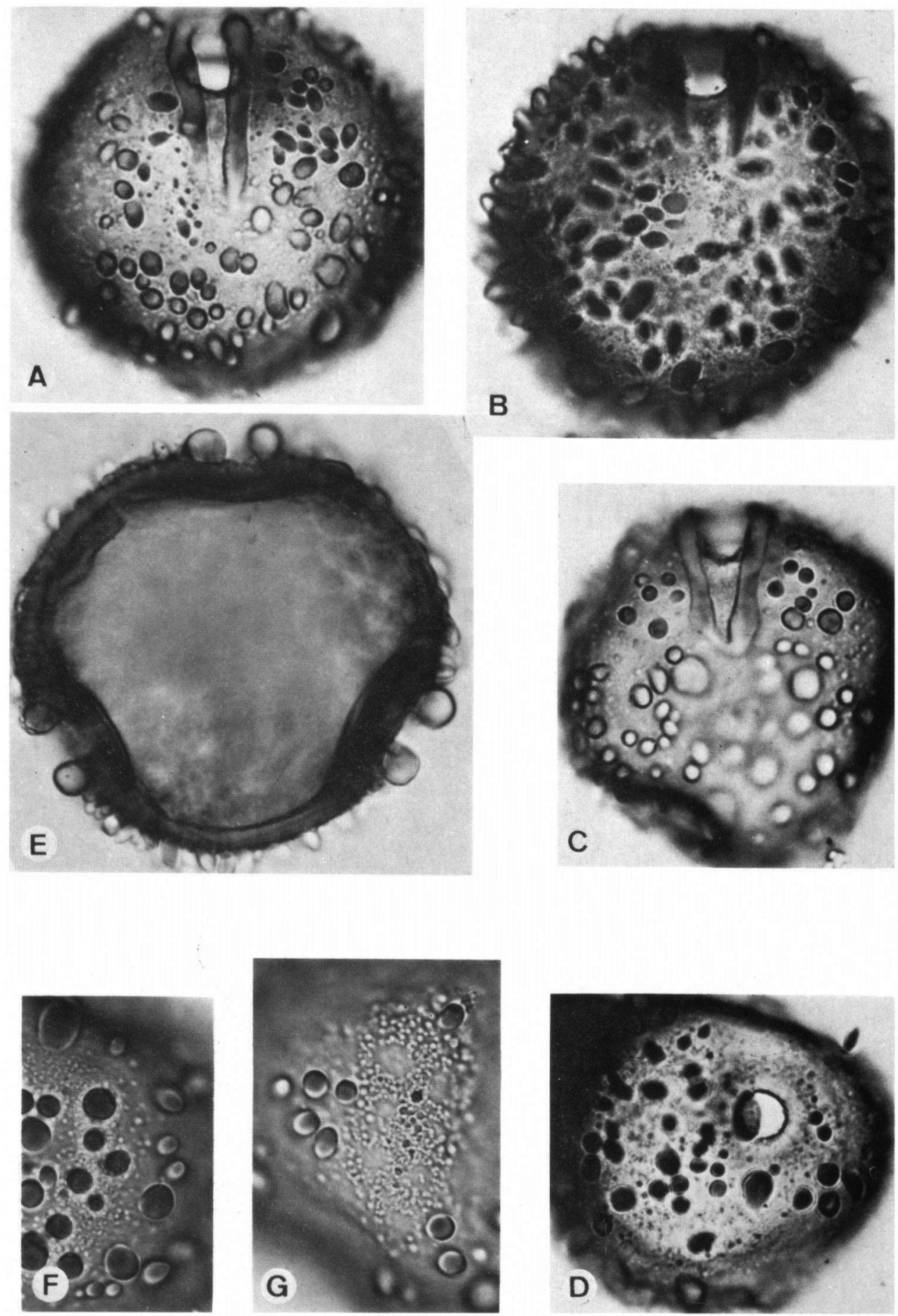
PLATE VI
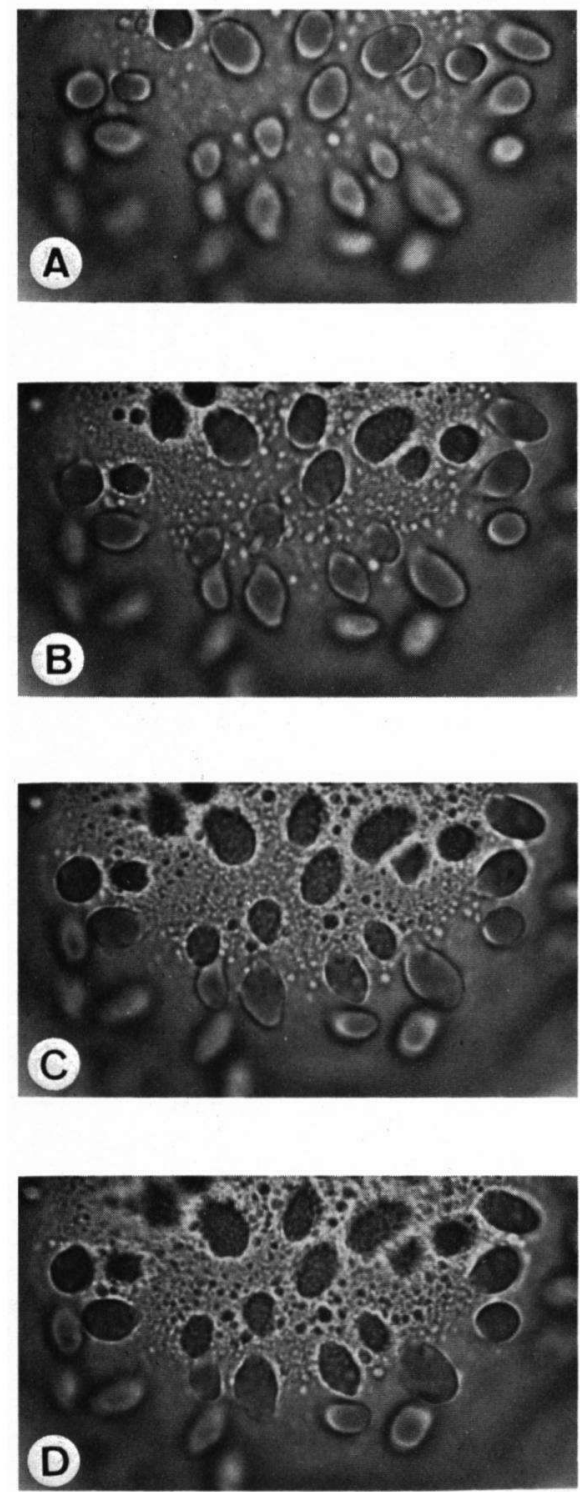

E
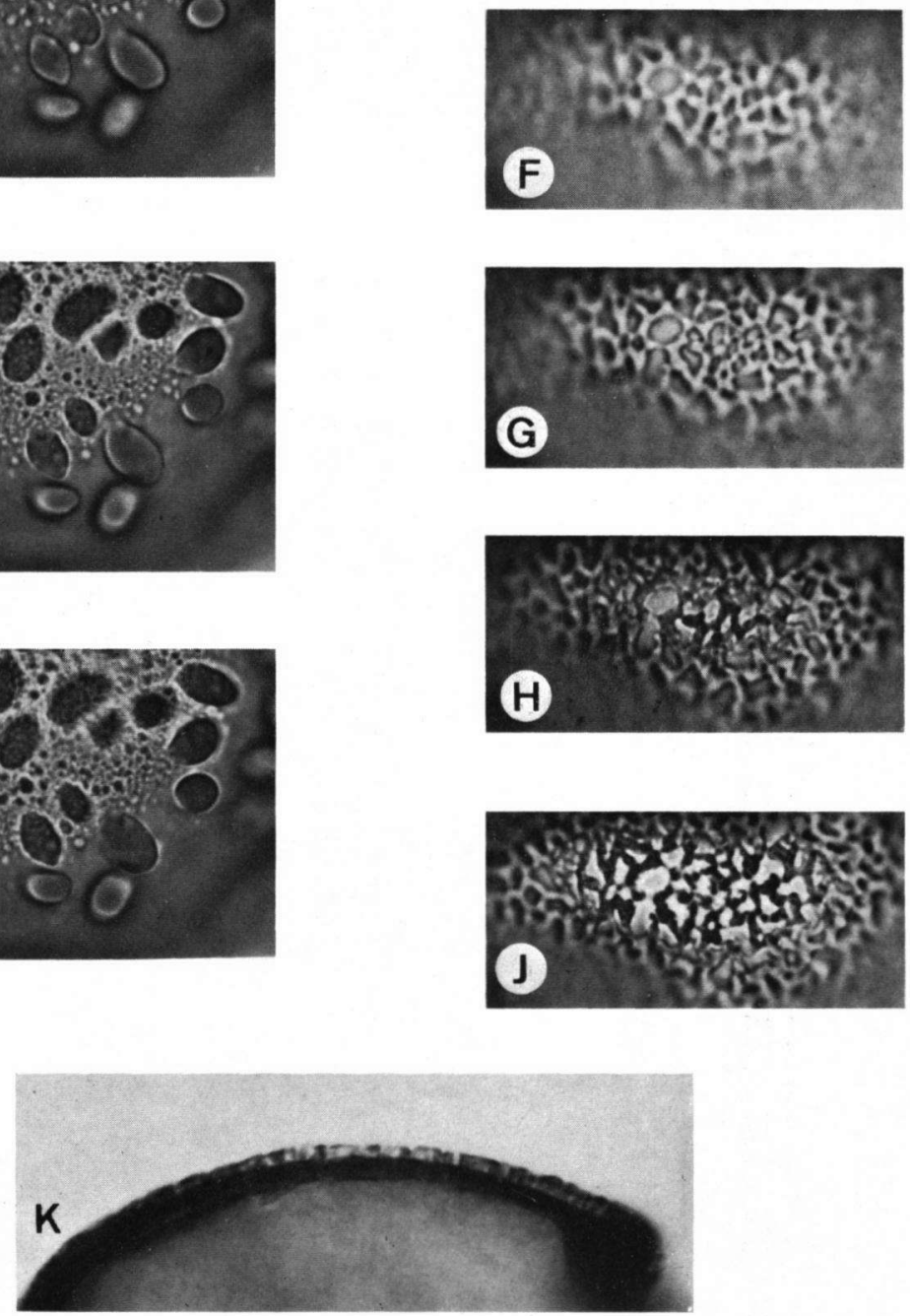

Rev. Palaeobotan. Palynol., 10 (1970) 249-332 

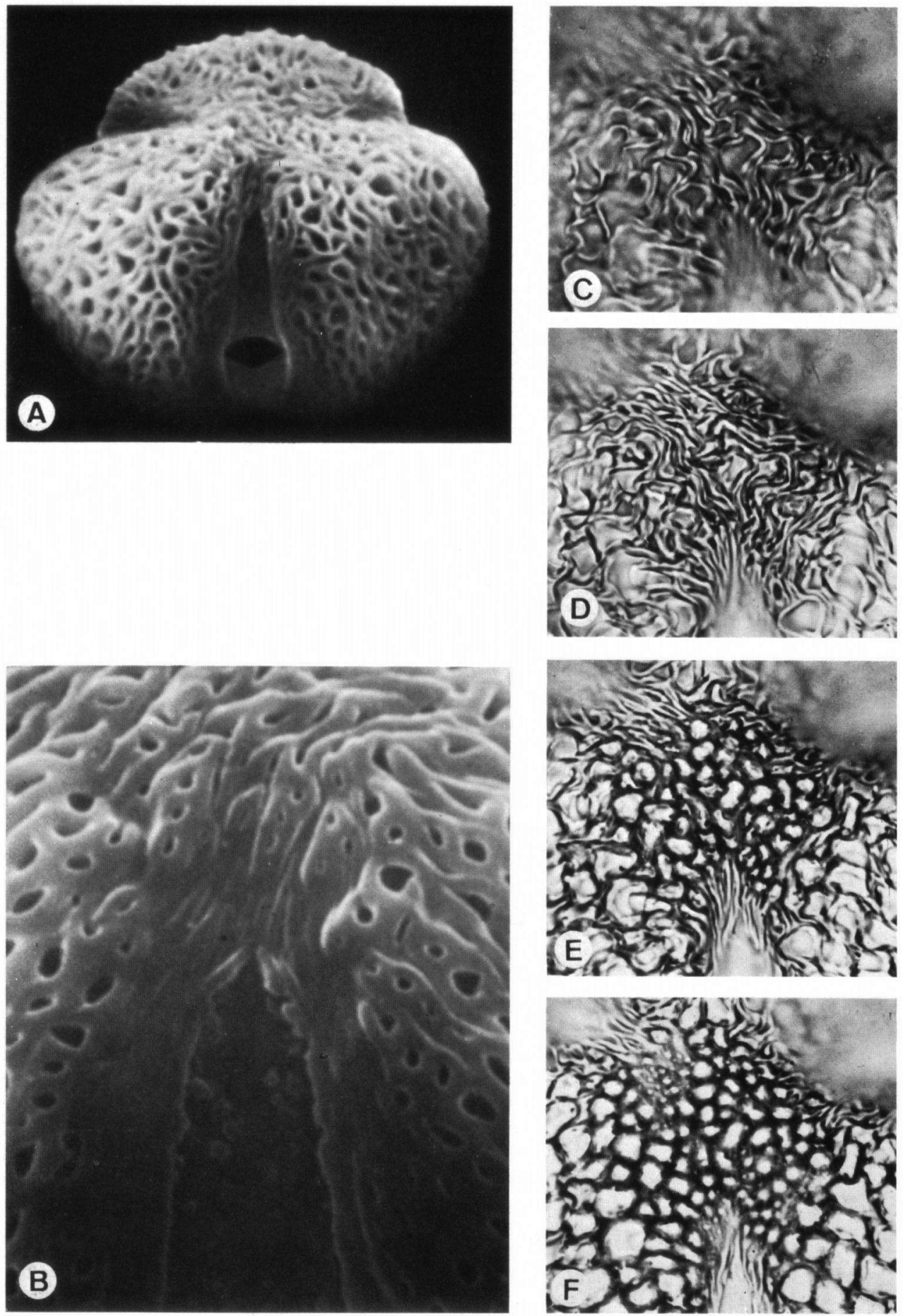


\section{PLATE VIII}
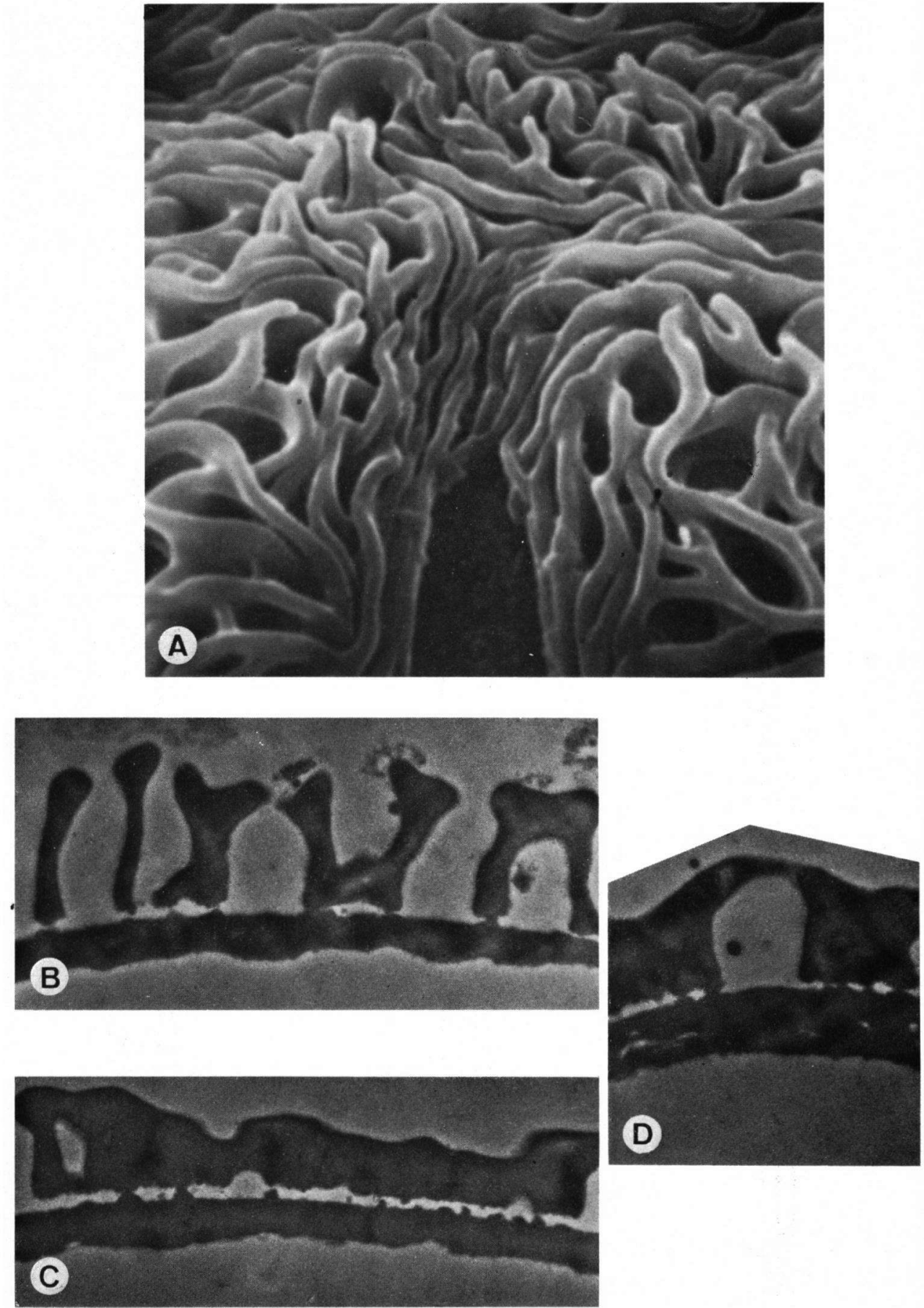

(D)

Rev. Palaeobotan. Palynol., 10 (1970) 249-332 


\section{PLATE IX}
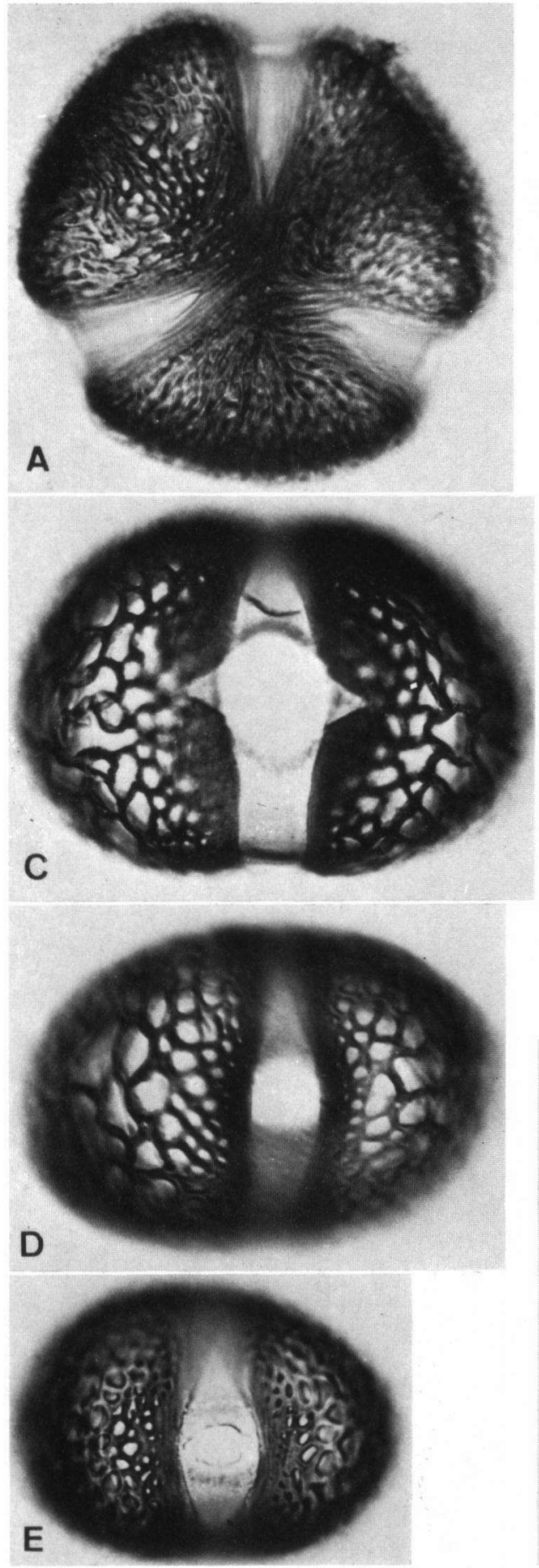
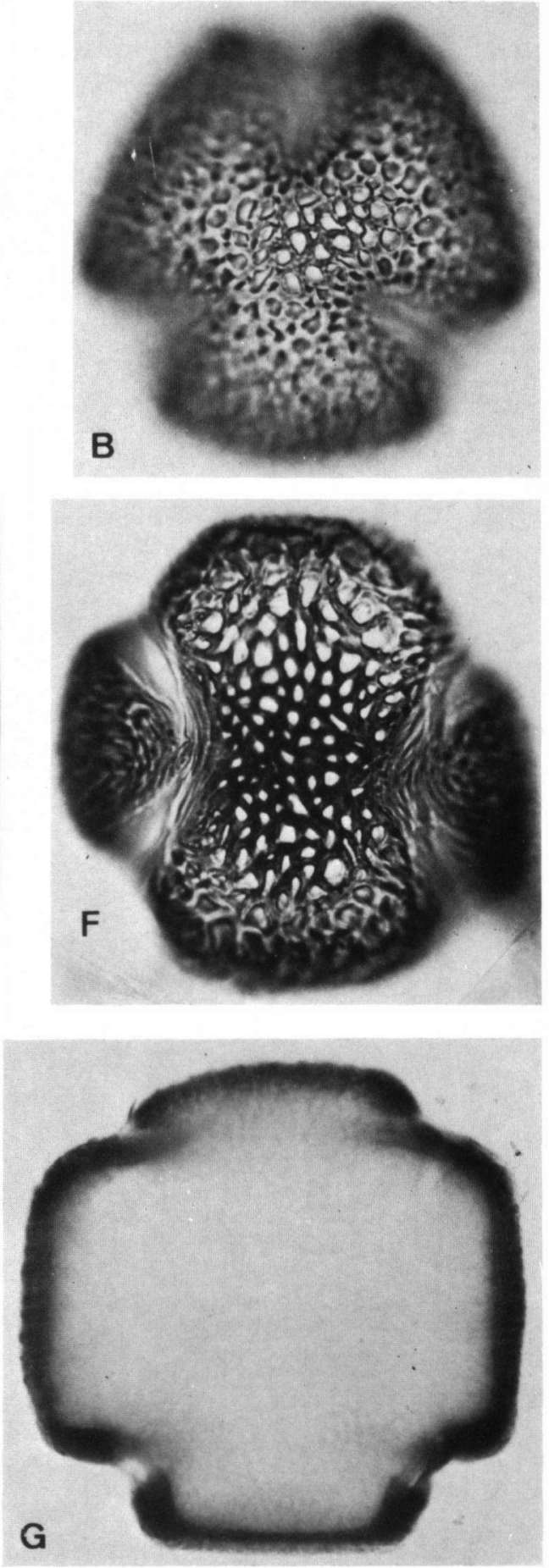

Rev. Palaeobotan. Palynol., 10 (1970) 249-332 
PLATE $X$
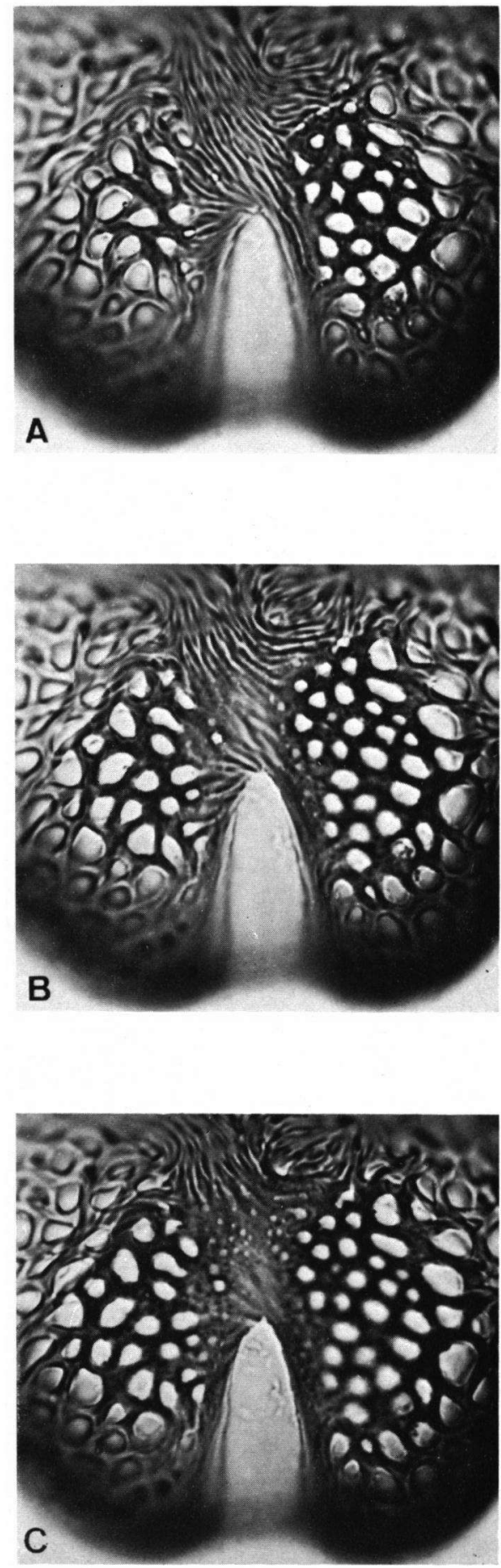

Rev. Palaeobotan. Palynol., 10 (1970) 249-332
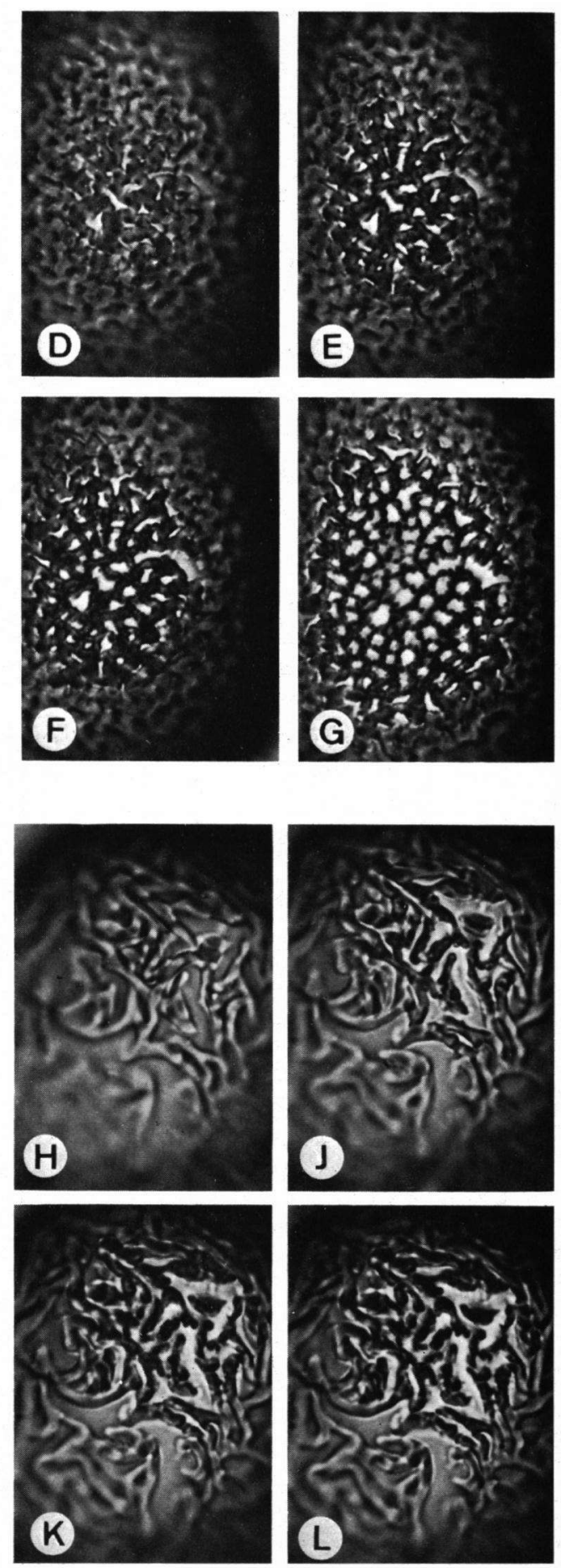


\section{PLATE XI}
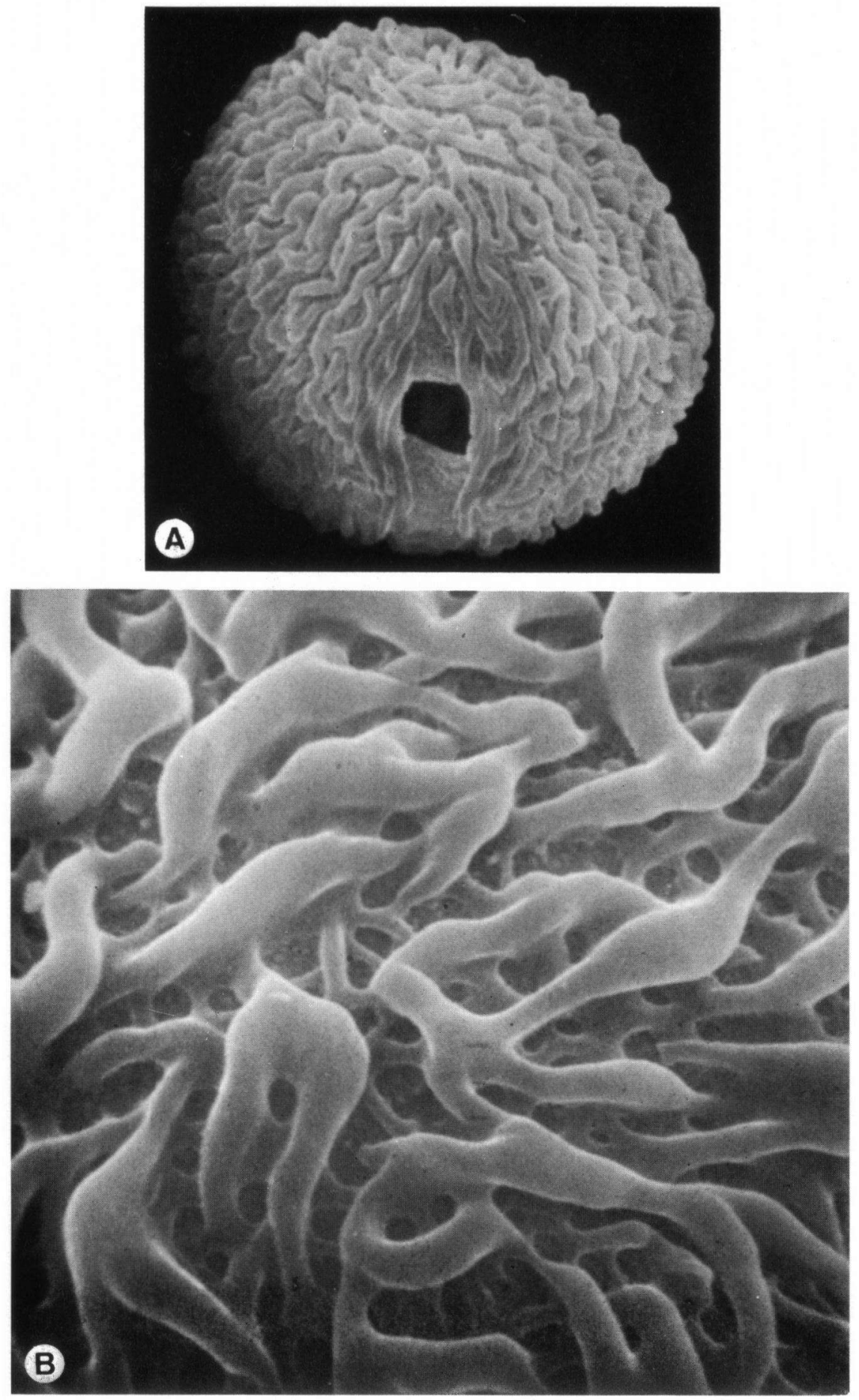
PLATE XII

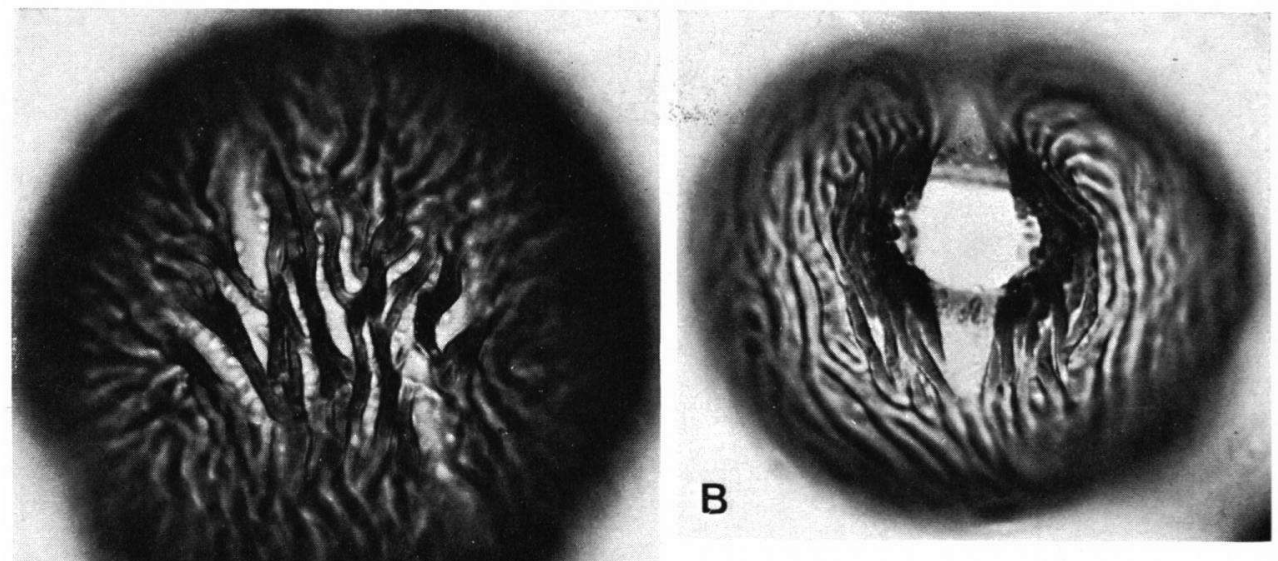

A
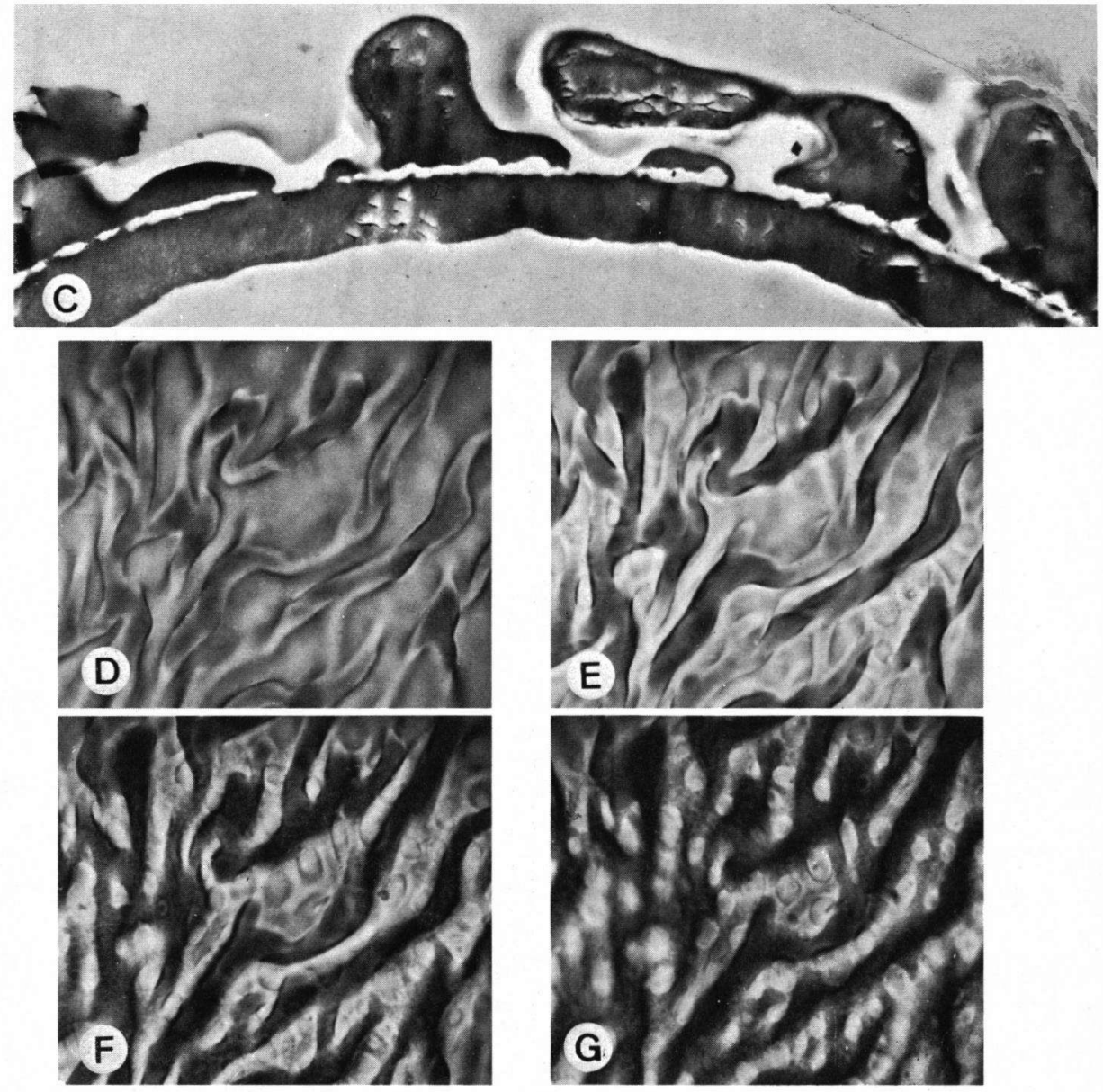

Rev. Palaeobotan. Palynol., 10 (1970) 249-332 
PLATE XIII
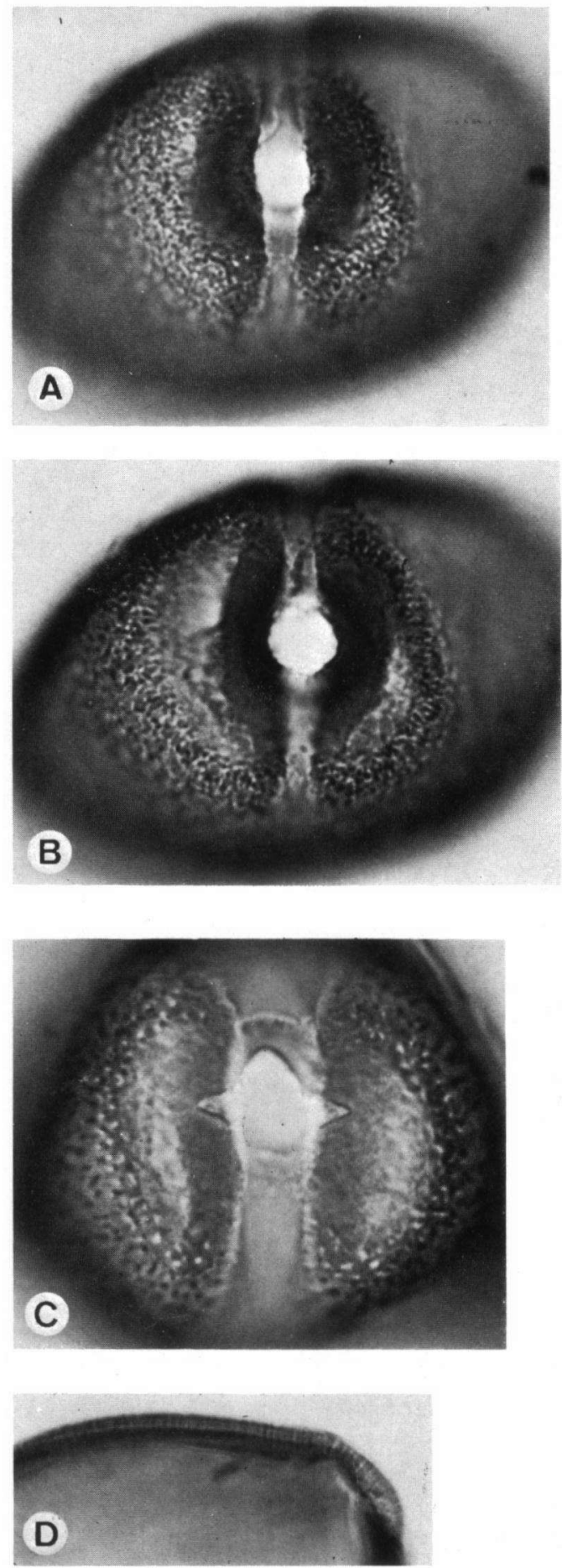

312
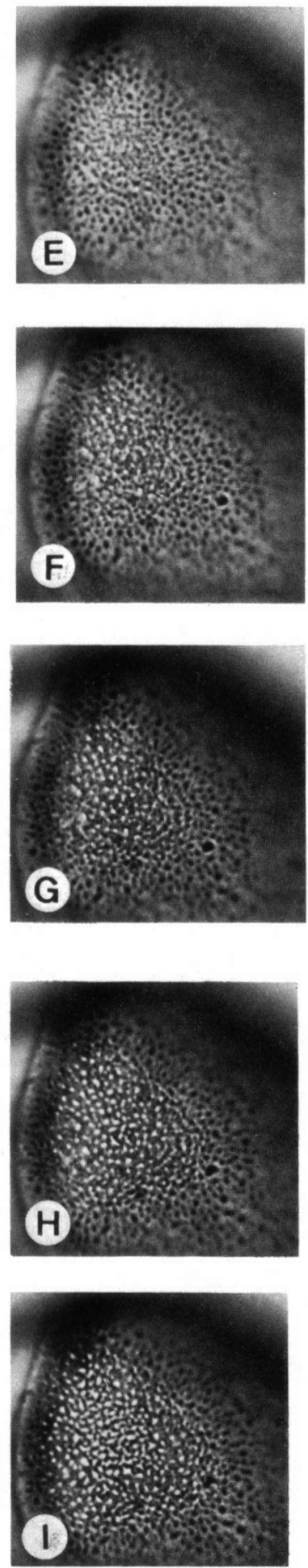

Rev. Palaeobotan. Palynol., 10 (1970) 249-332 


\section{PLATE XIV}
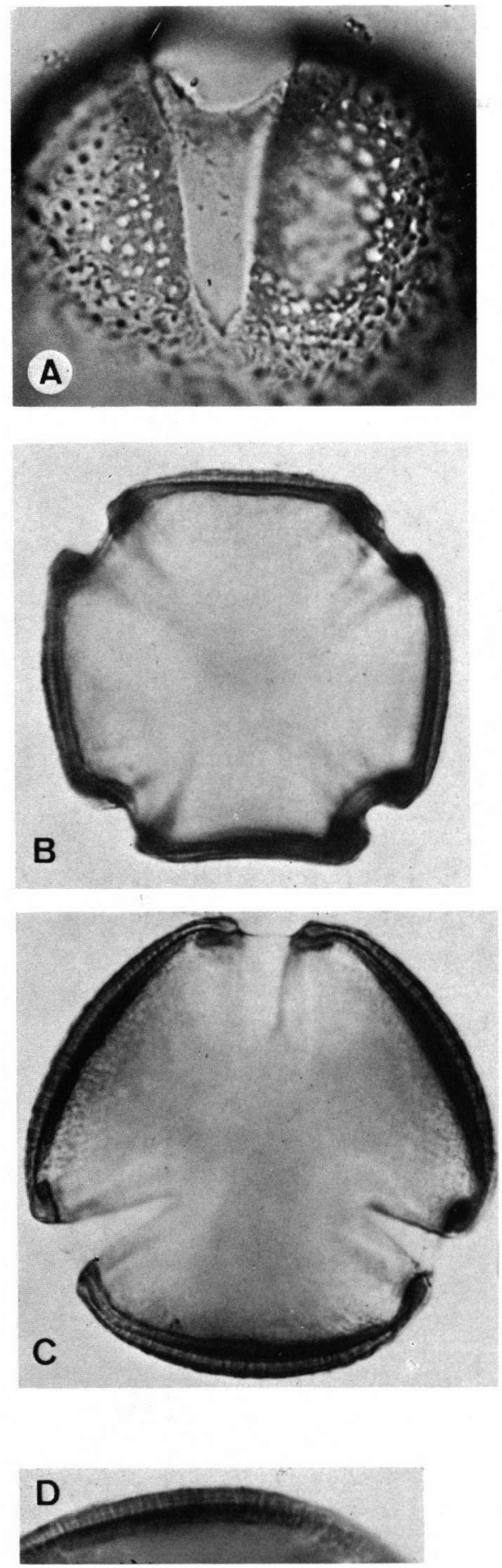

Rev. Palaeobotan. Palynol., 10 (1970) 249-332
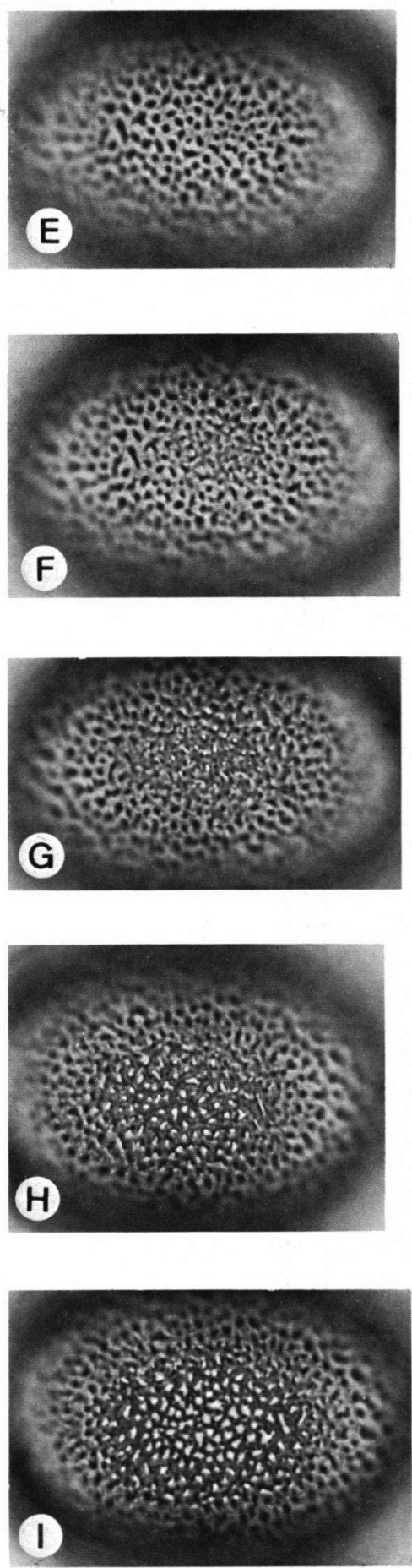


\section{PLATE XV}
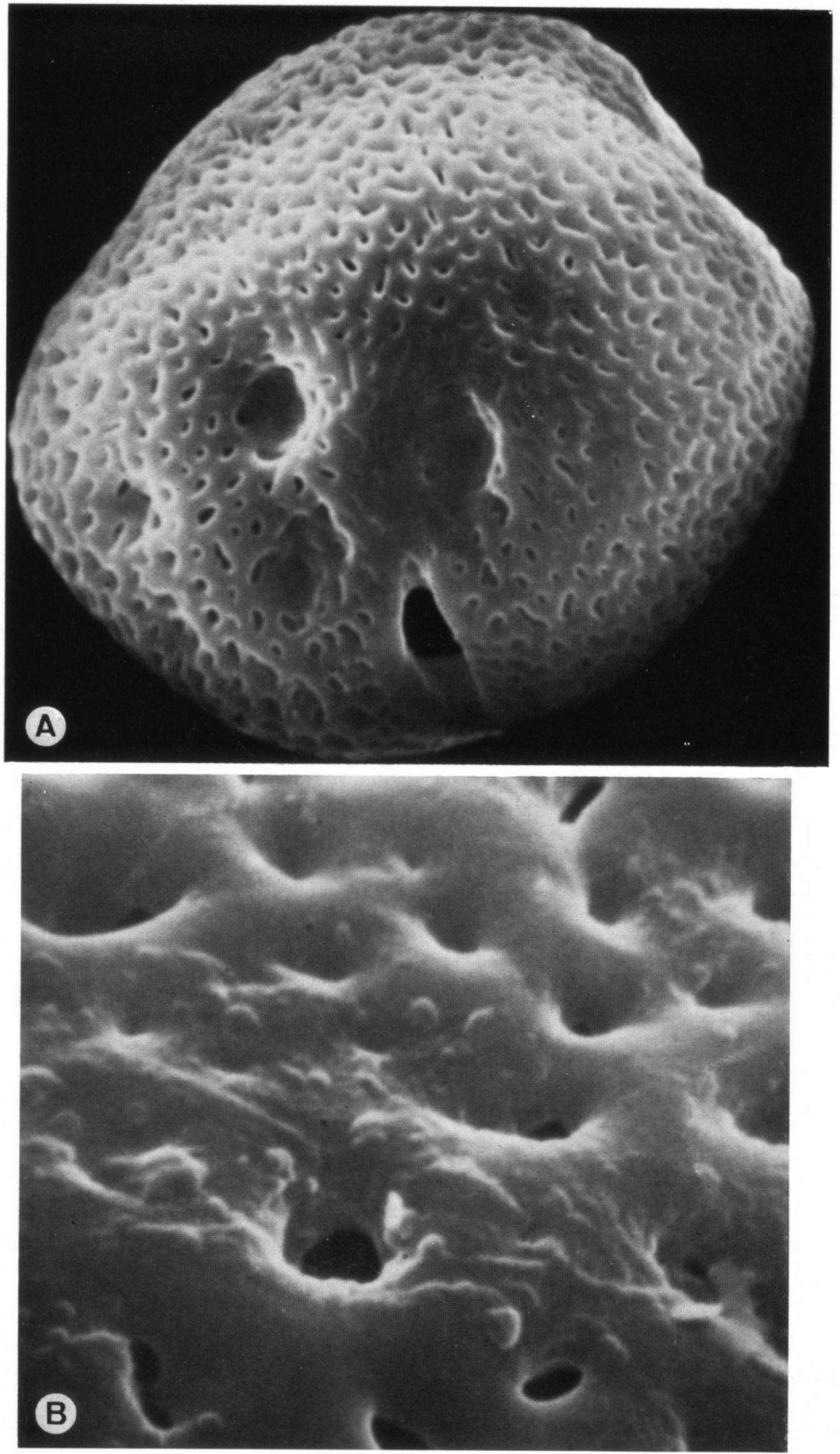
PLATE XVI
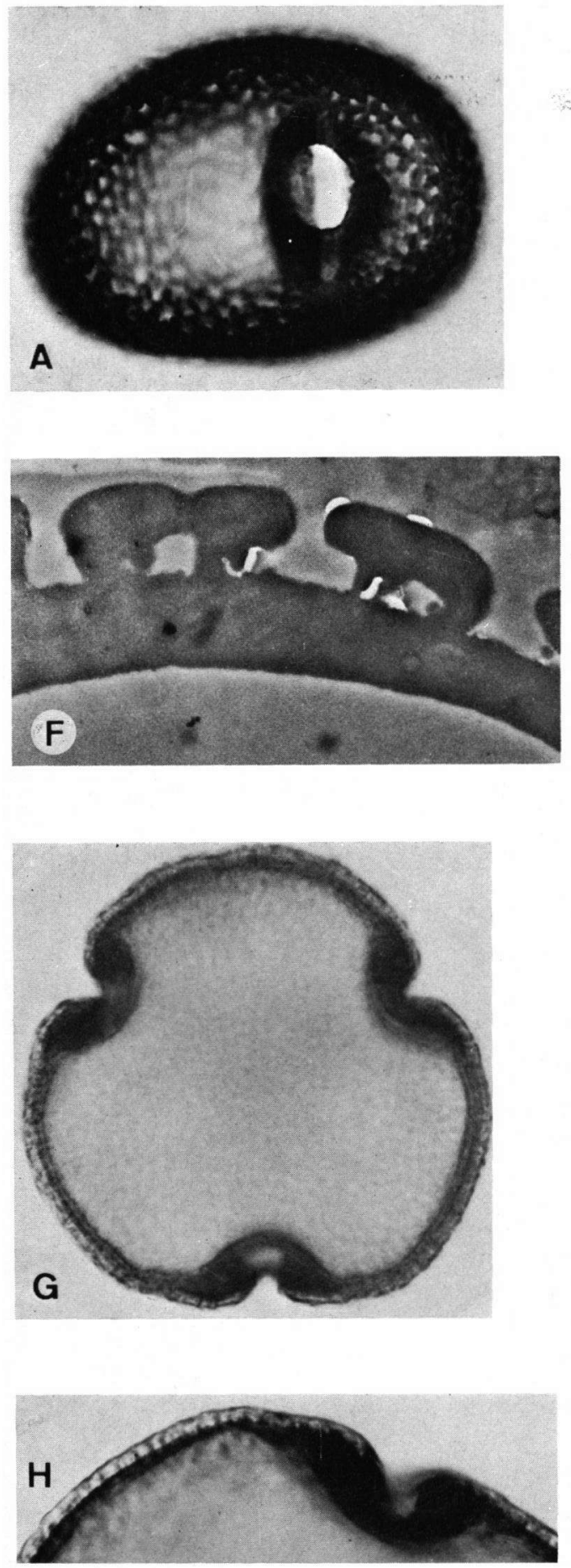

Rev. Palaeobotan. Palynol., 10 (1970) 249-332
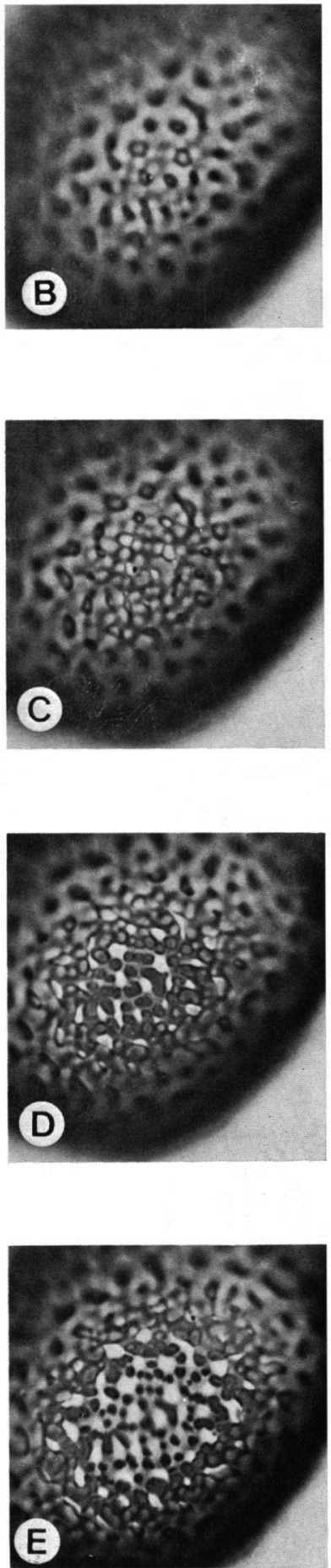


\section{PLATE XVII}
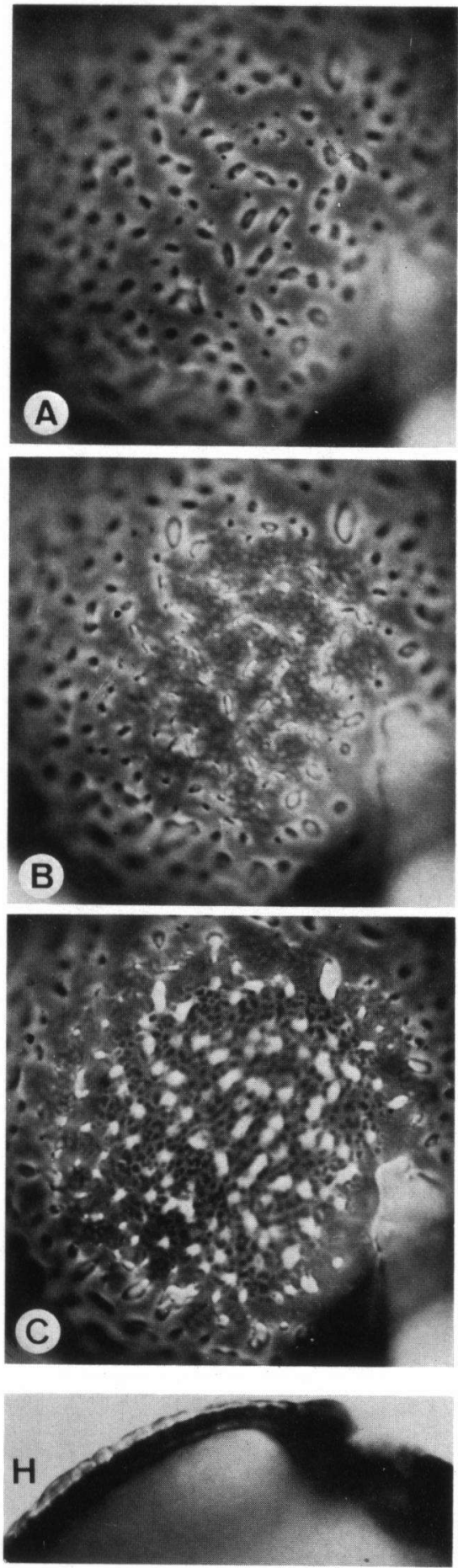
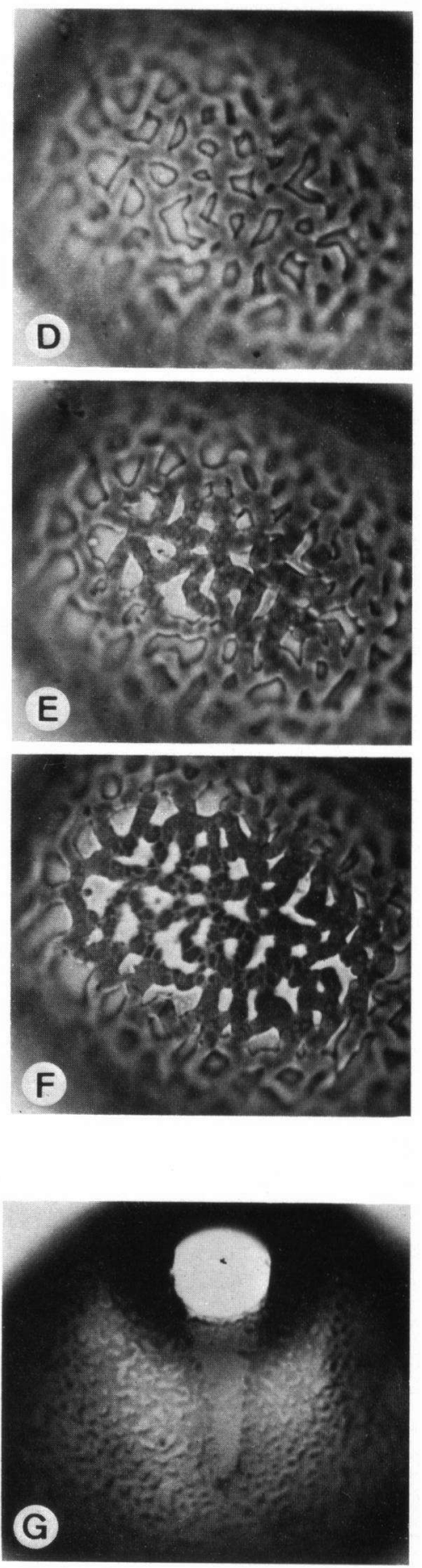

Rev. Palaeobotan. Palynol., 10 (1970) 249-332 


\section{PLATE XVIII}
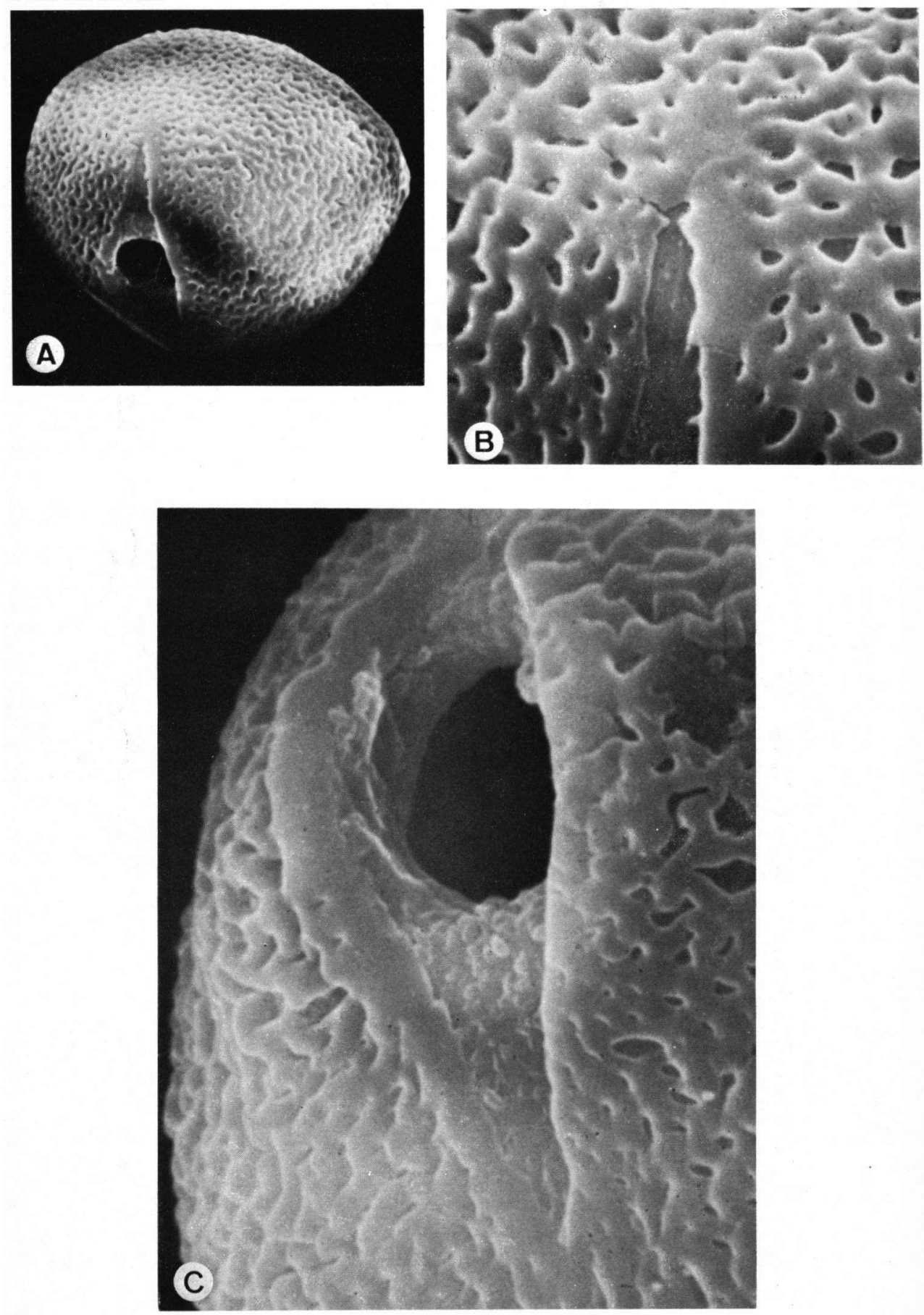

Rev. Palaeobotan. Palynol., 10 (1970) 249-332 


\section{PLATE XIX}
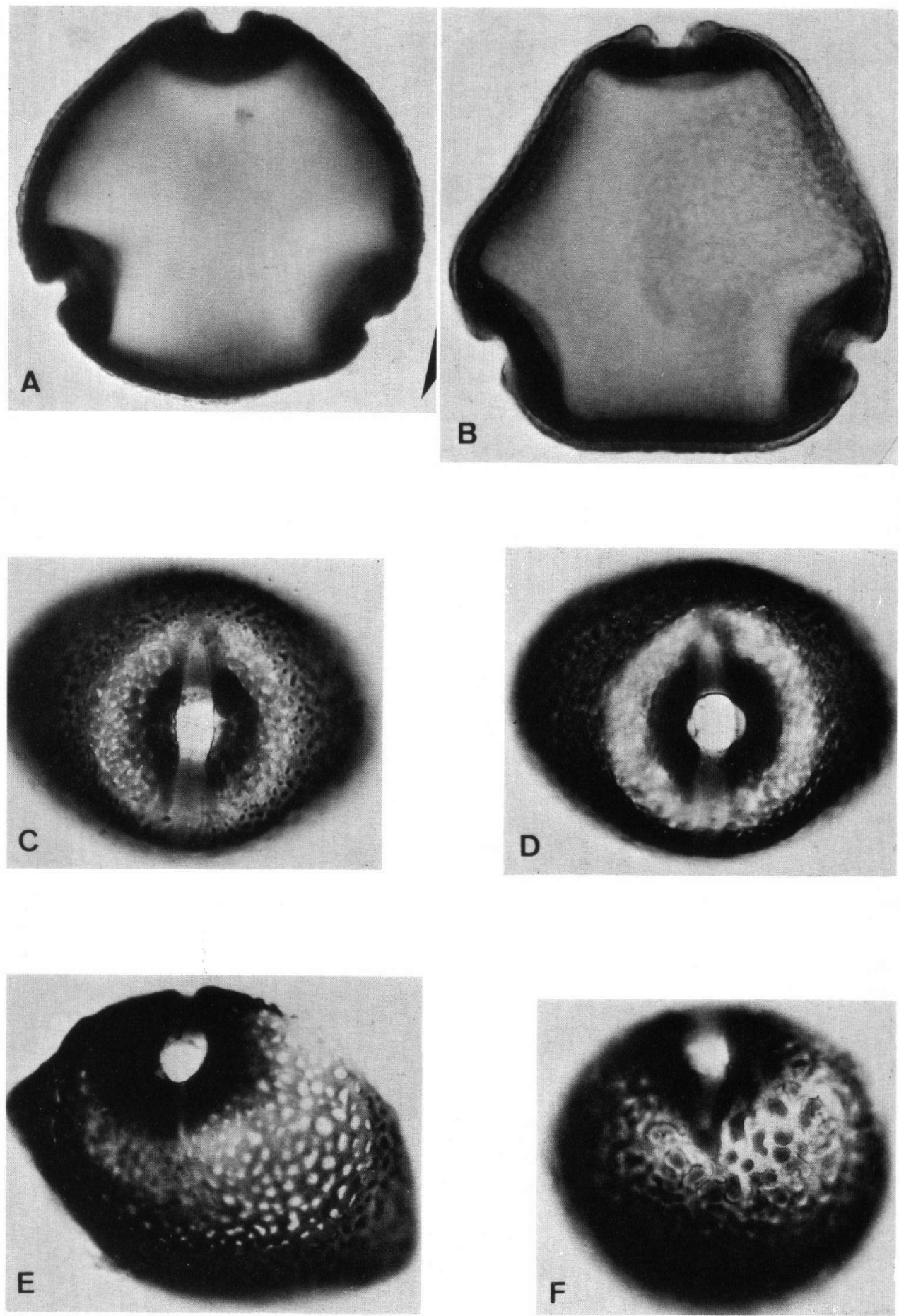
PLATE XX

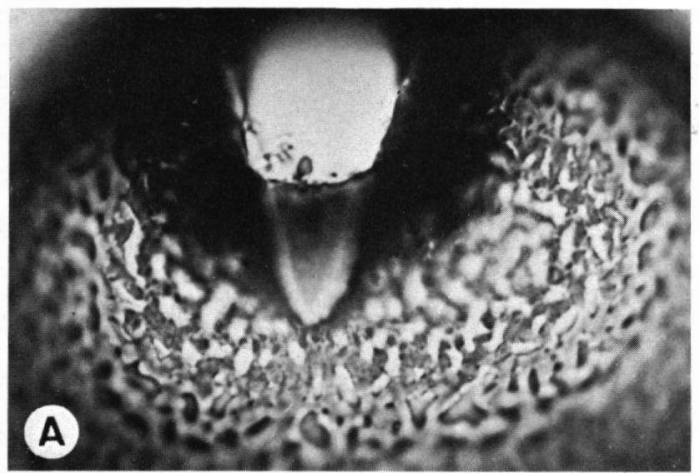

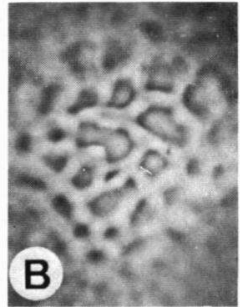
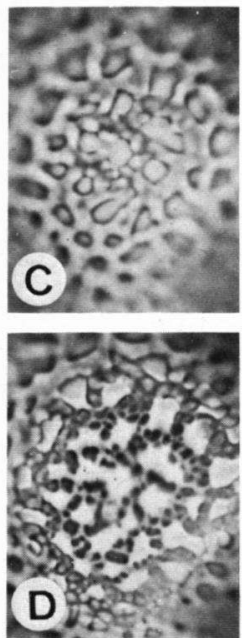
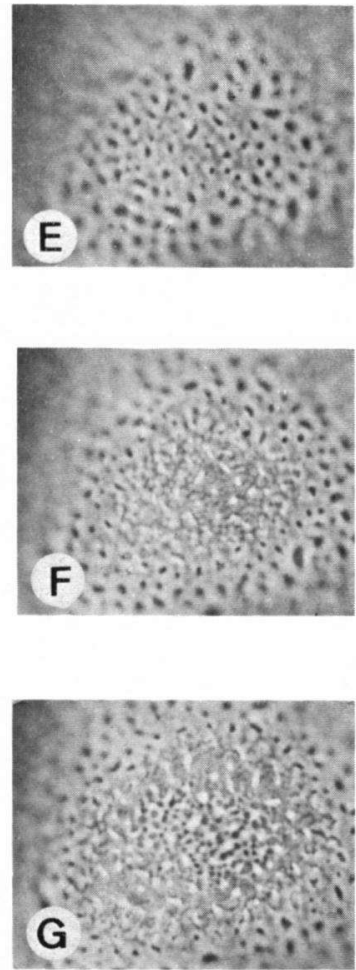
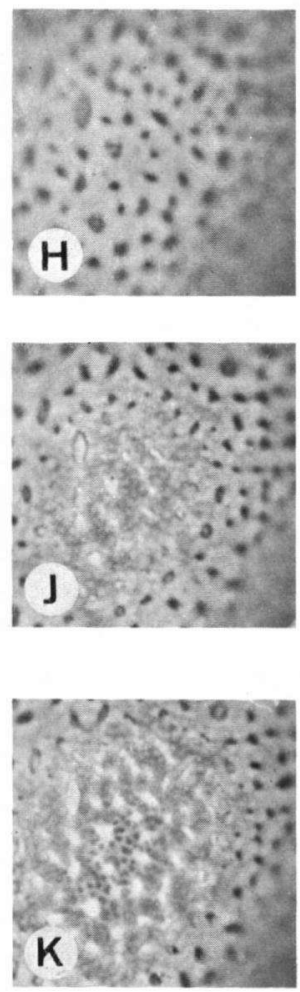
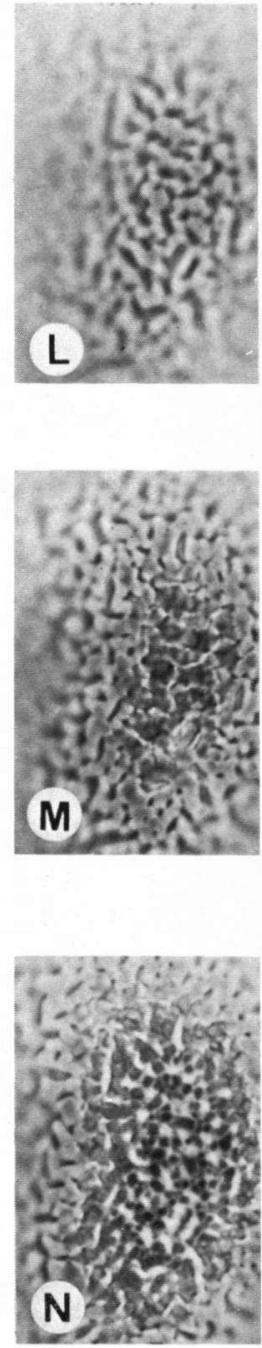
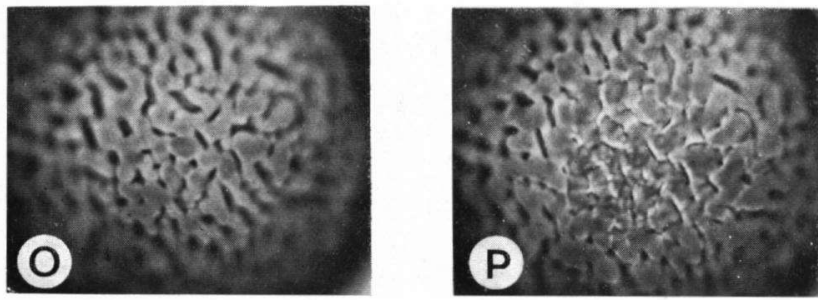

Rev. Palaeobotan. Palynol., 10 (1970) 249-332

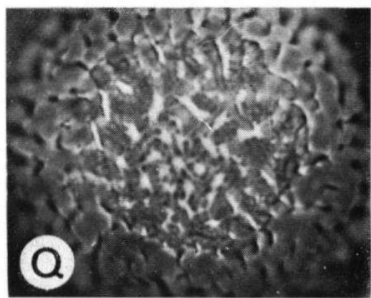


PLATE XXI
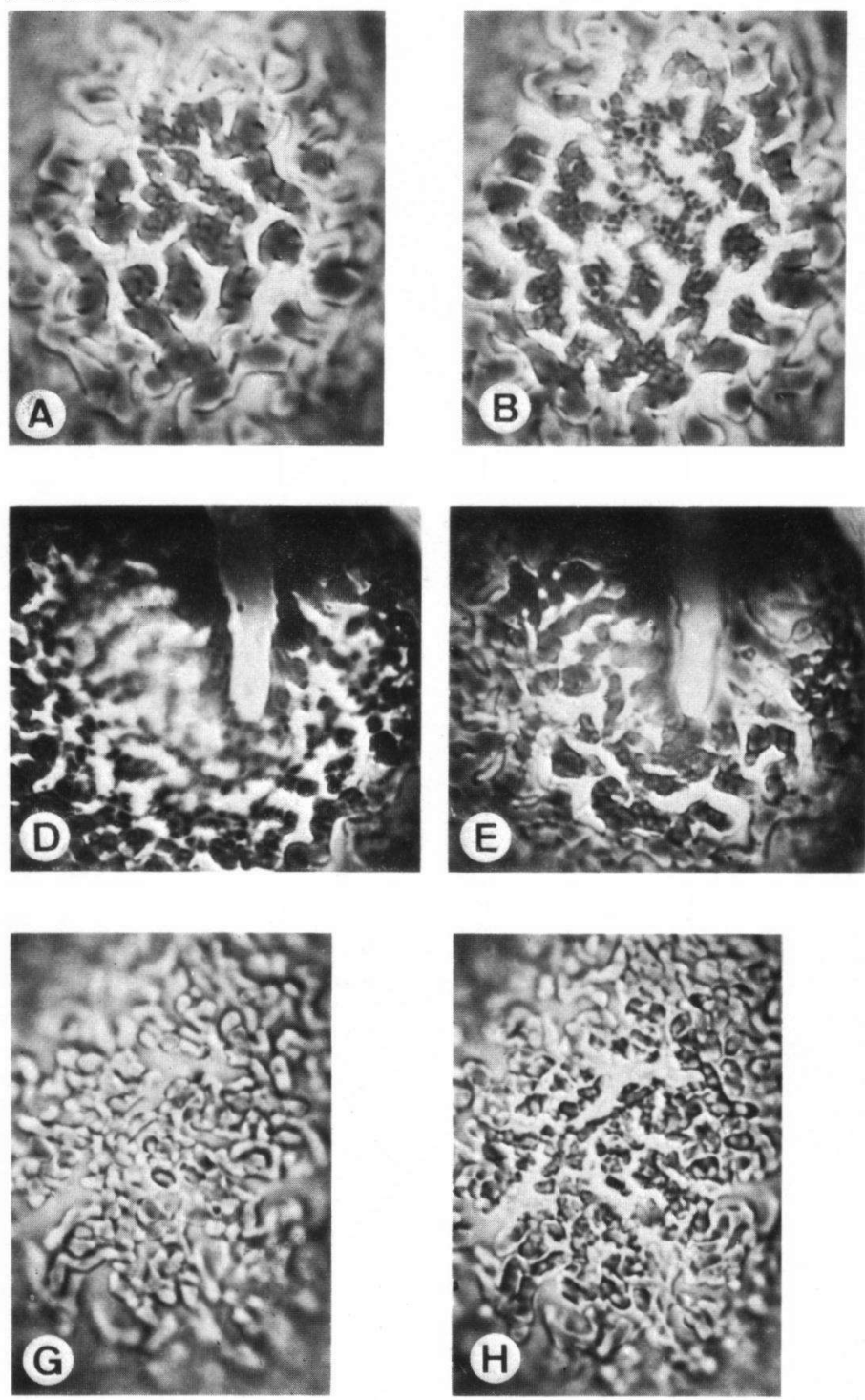
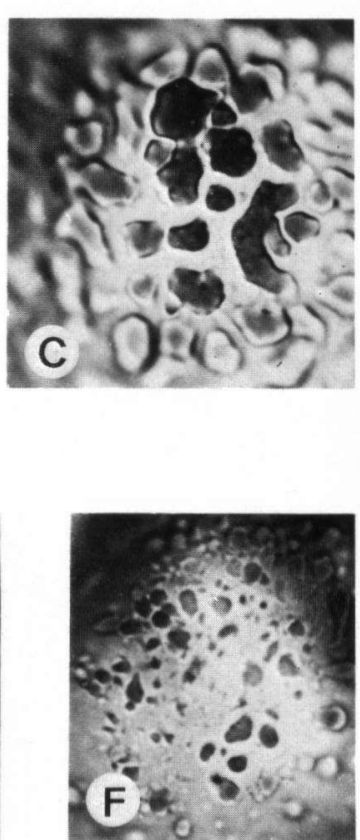

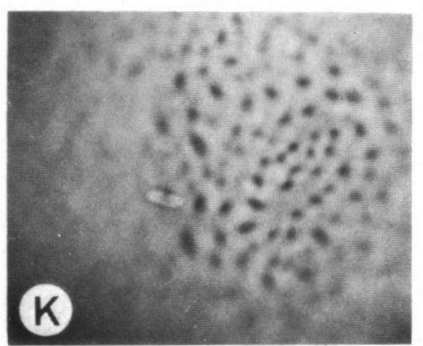

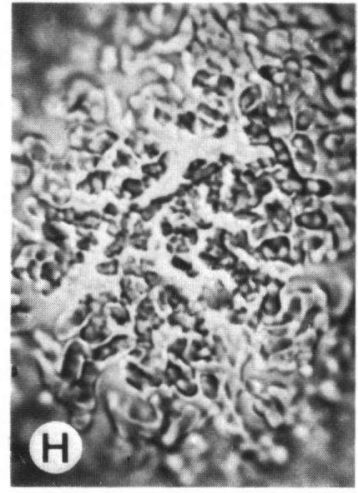

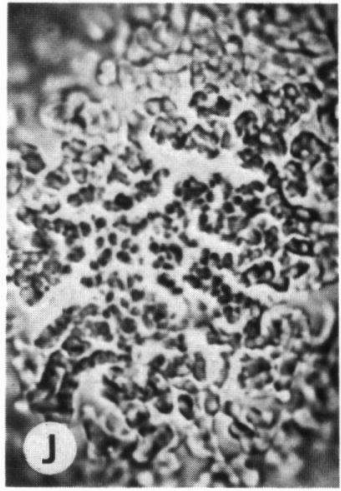

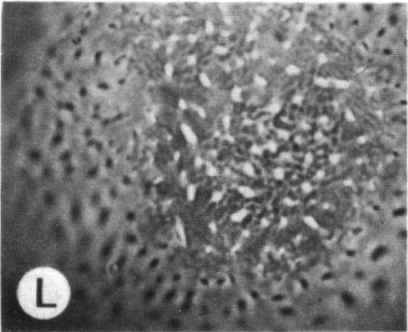

Rev. Palaeobotan. Palynol., 10 (1970) 249-332 


\section{PLATE XXII}
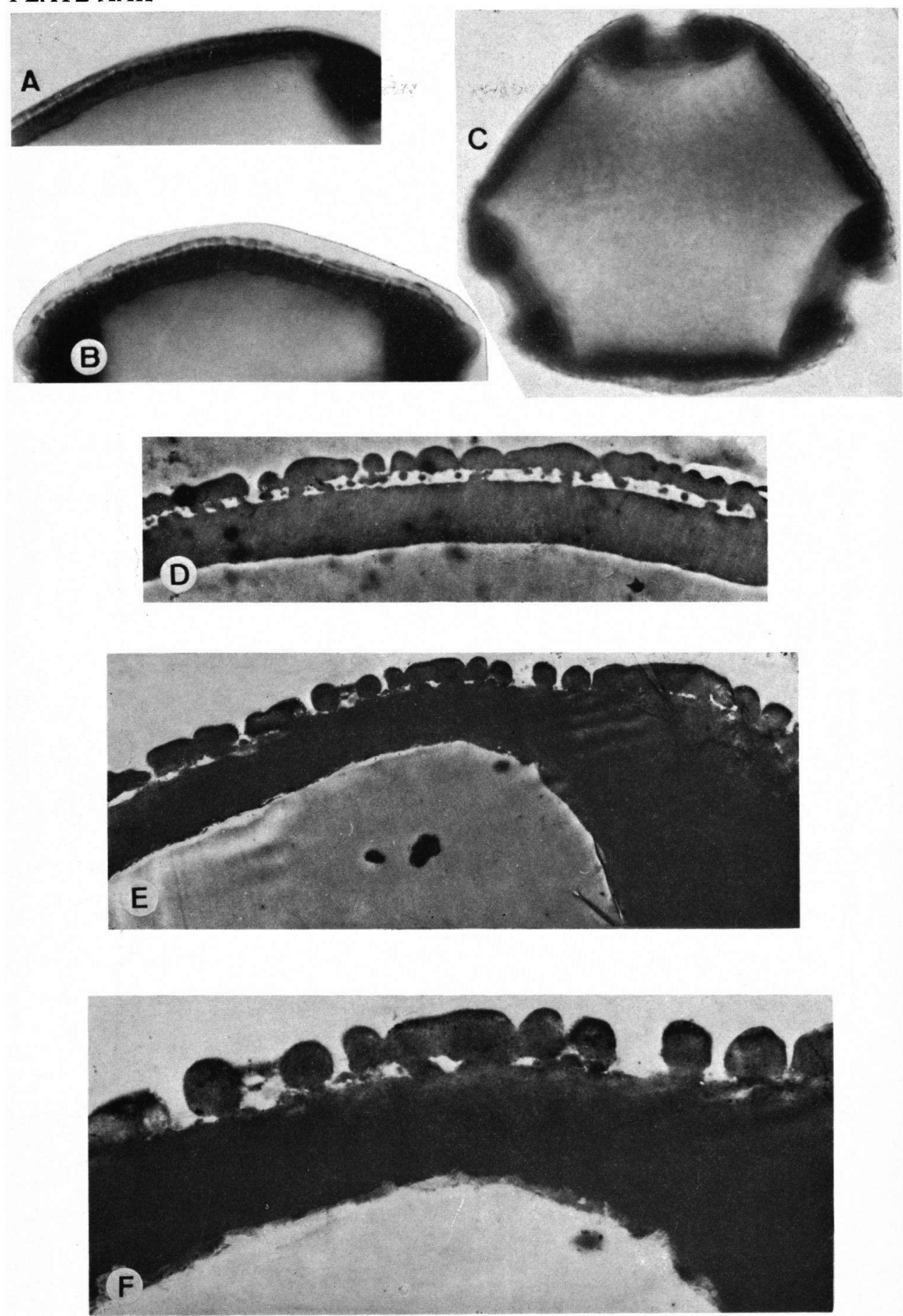

Rev. Palaeobotan. Palynol., 10 (1970) 249-332 


\section{PLATE XXIII}
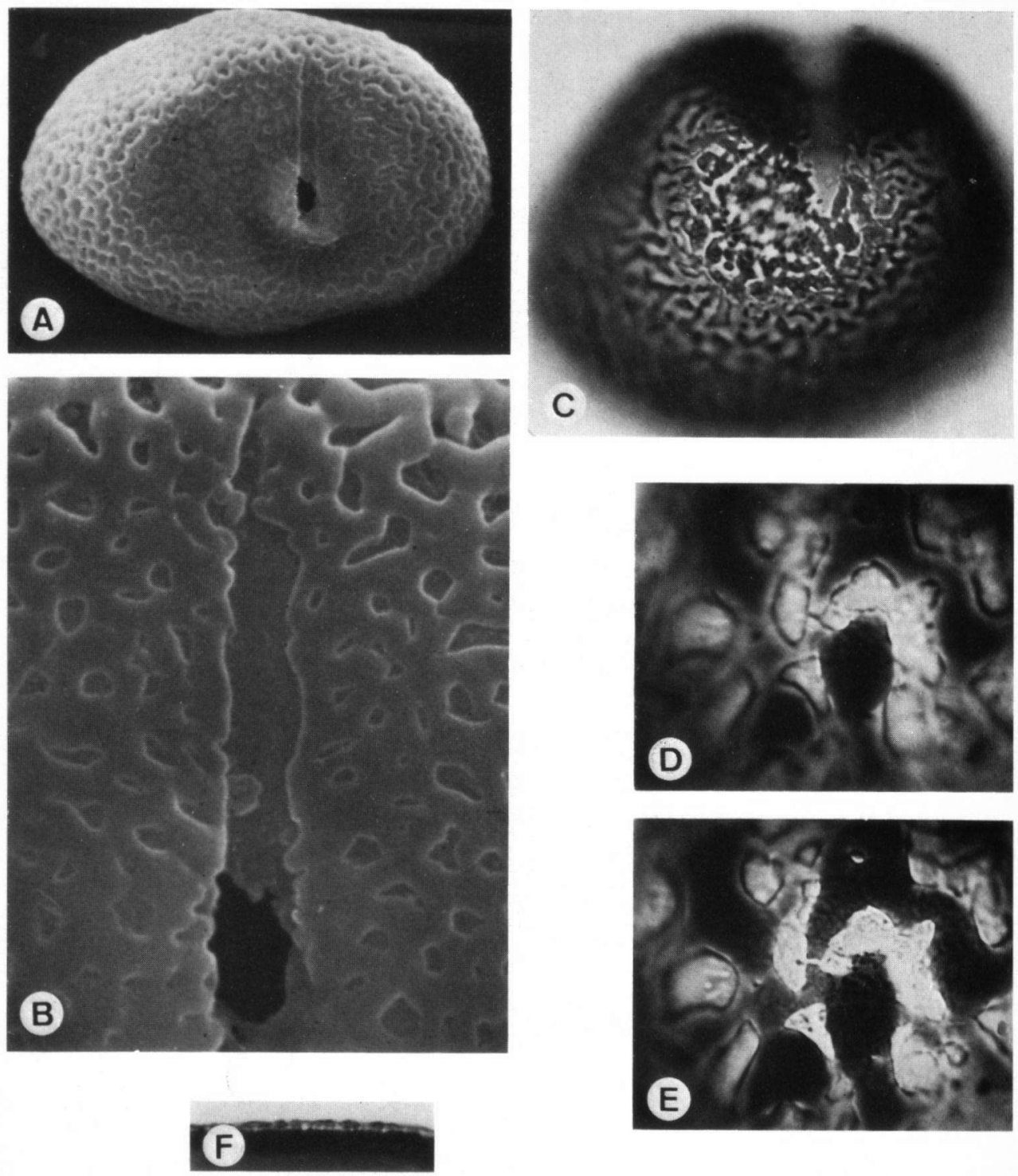

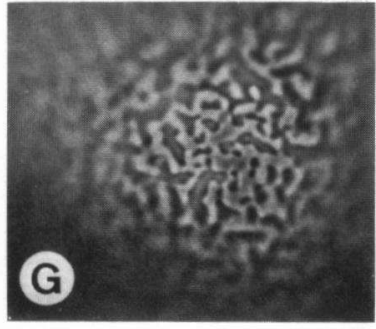

322
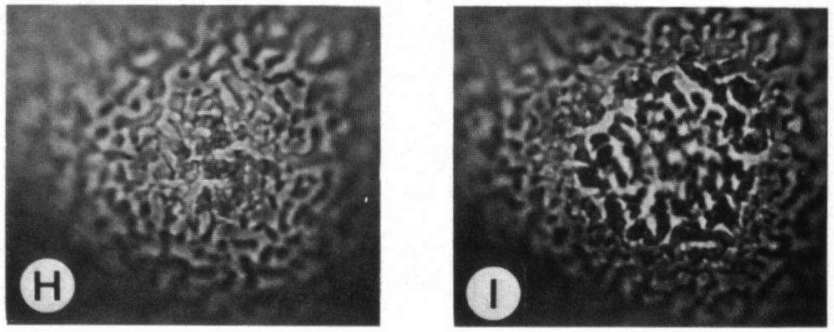

Rev. Palaeobotan. Palynol., 10 (1970) 249-322 


\section{PLATE XXIV}
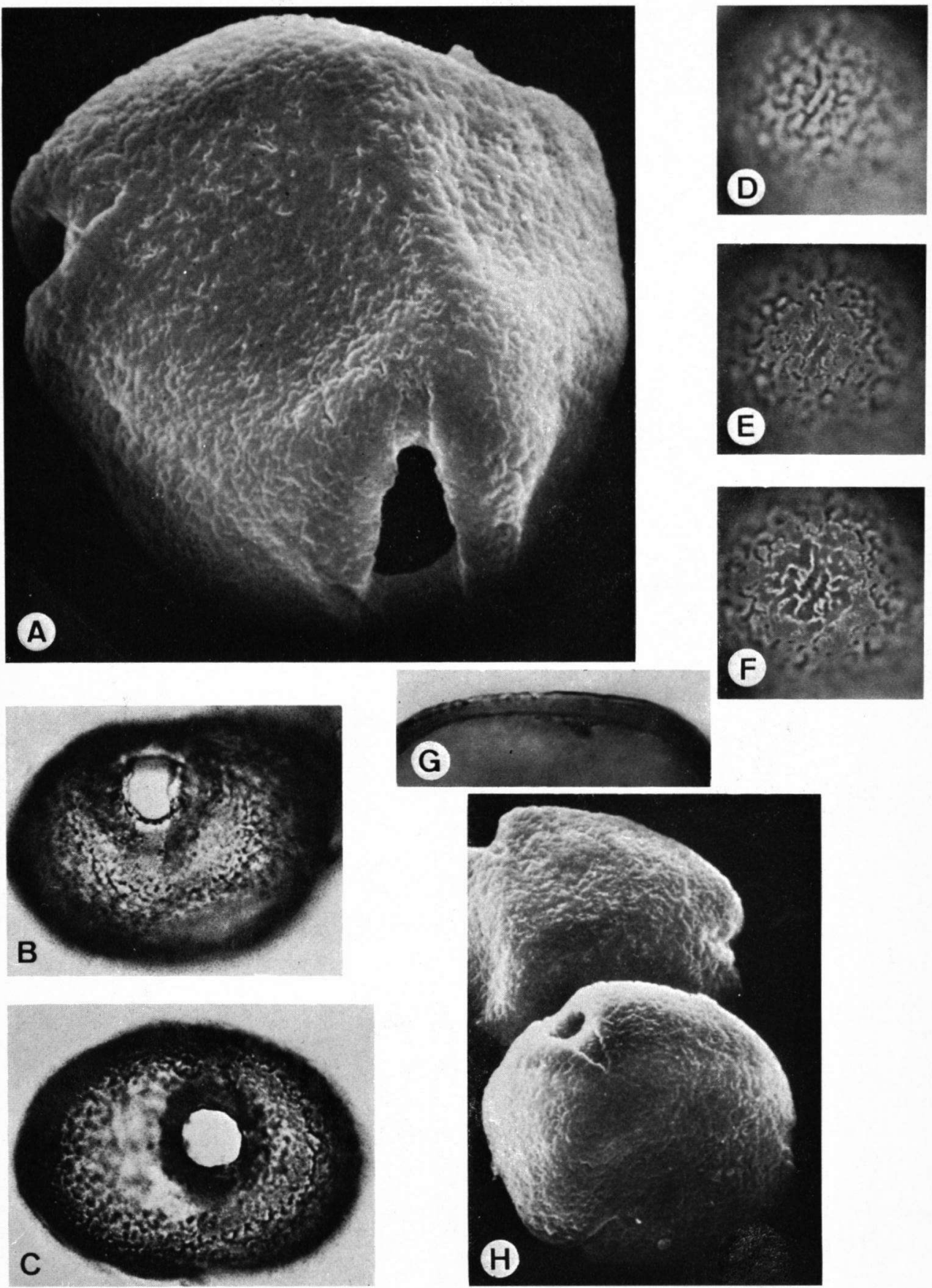

Rev. Palaeobotan. Palynol., 10 (1970) 249-332 


\section{PLATE XXV}
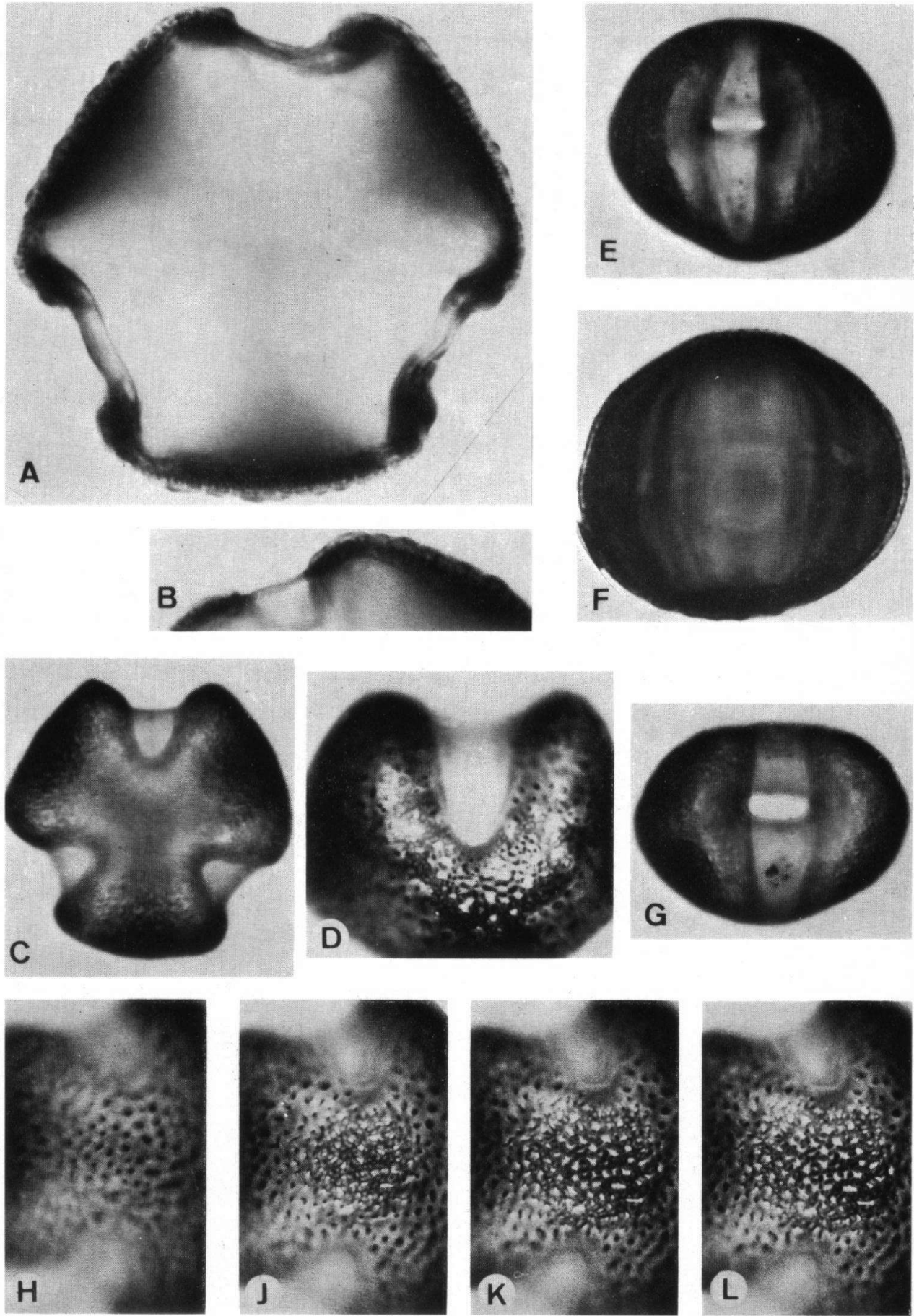


\section{PLATE XXVI}
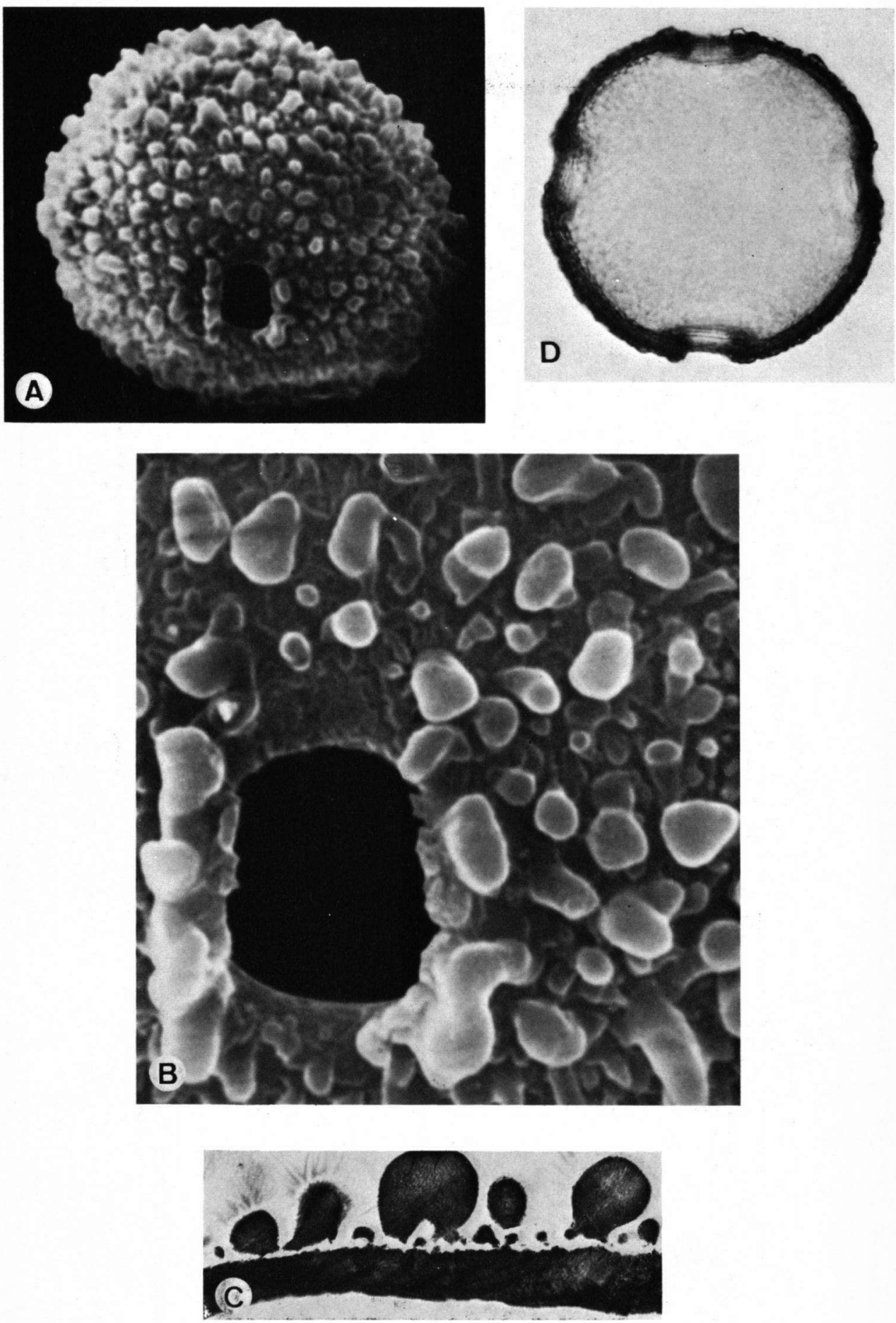
PLATE XXVII
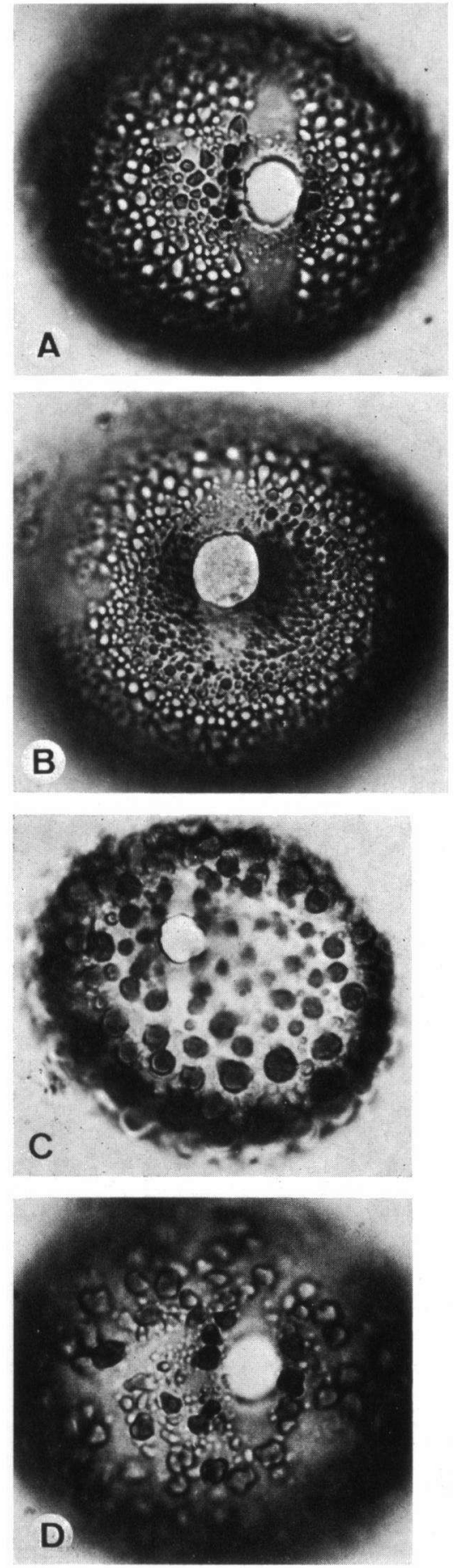
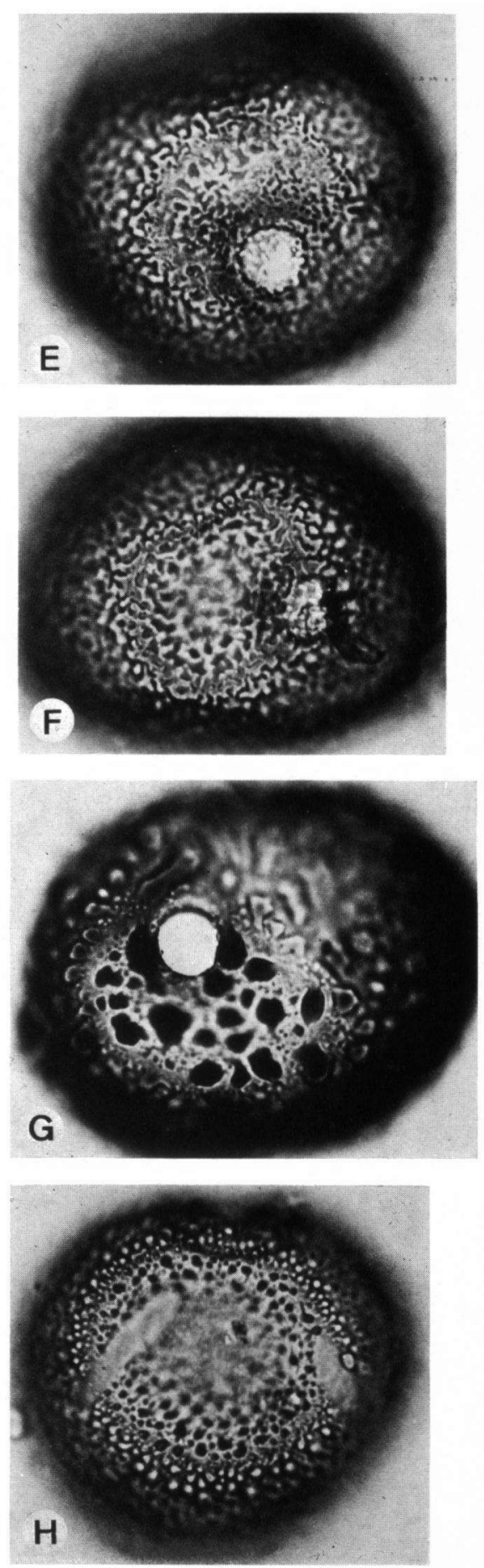

Rev. Palaeobotan. Palynol, 10 (1970) 249-332 
PLATE XXVIII
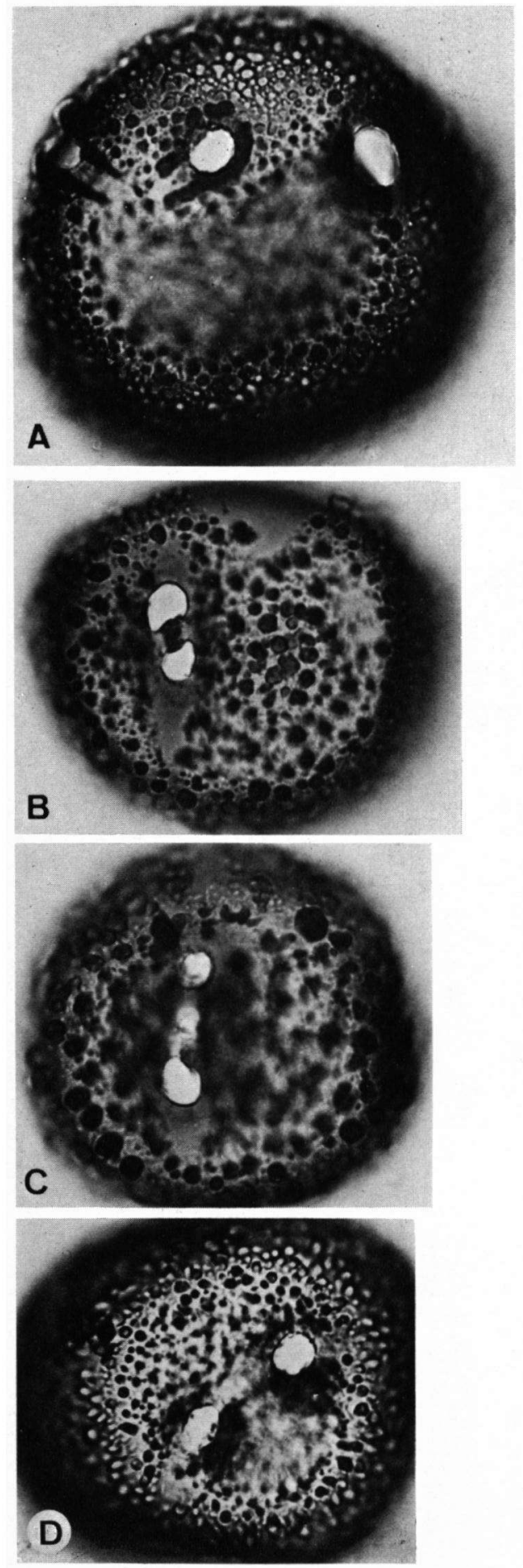
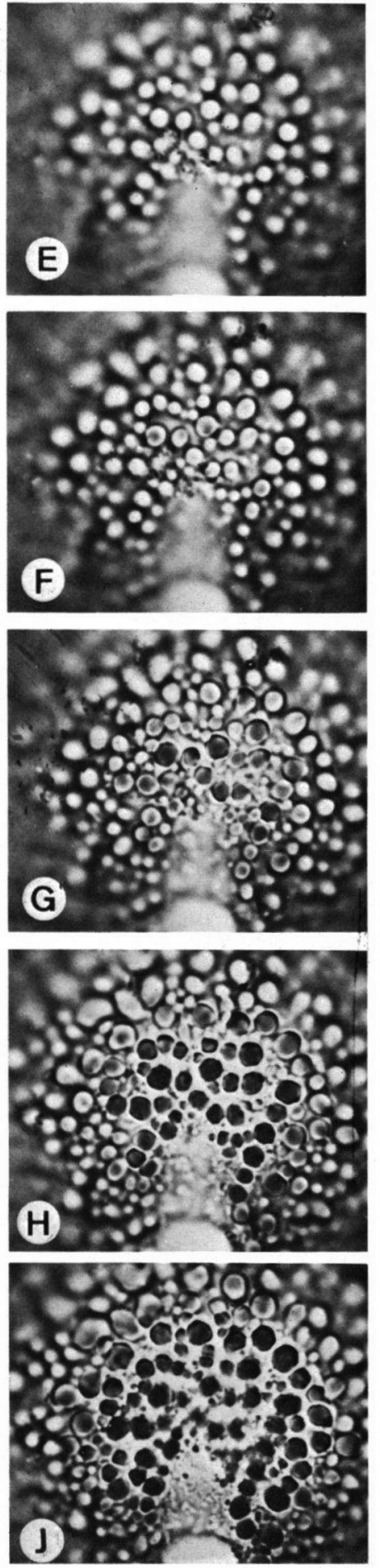

Rev. Palaeobotan. Palynol., 10 (1970) 249-332 
PLATE XXIX
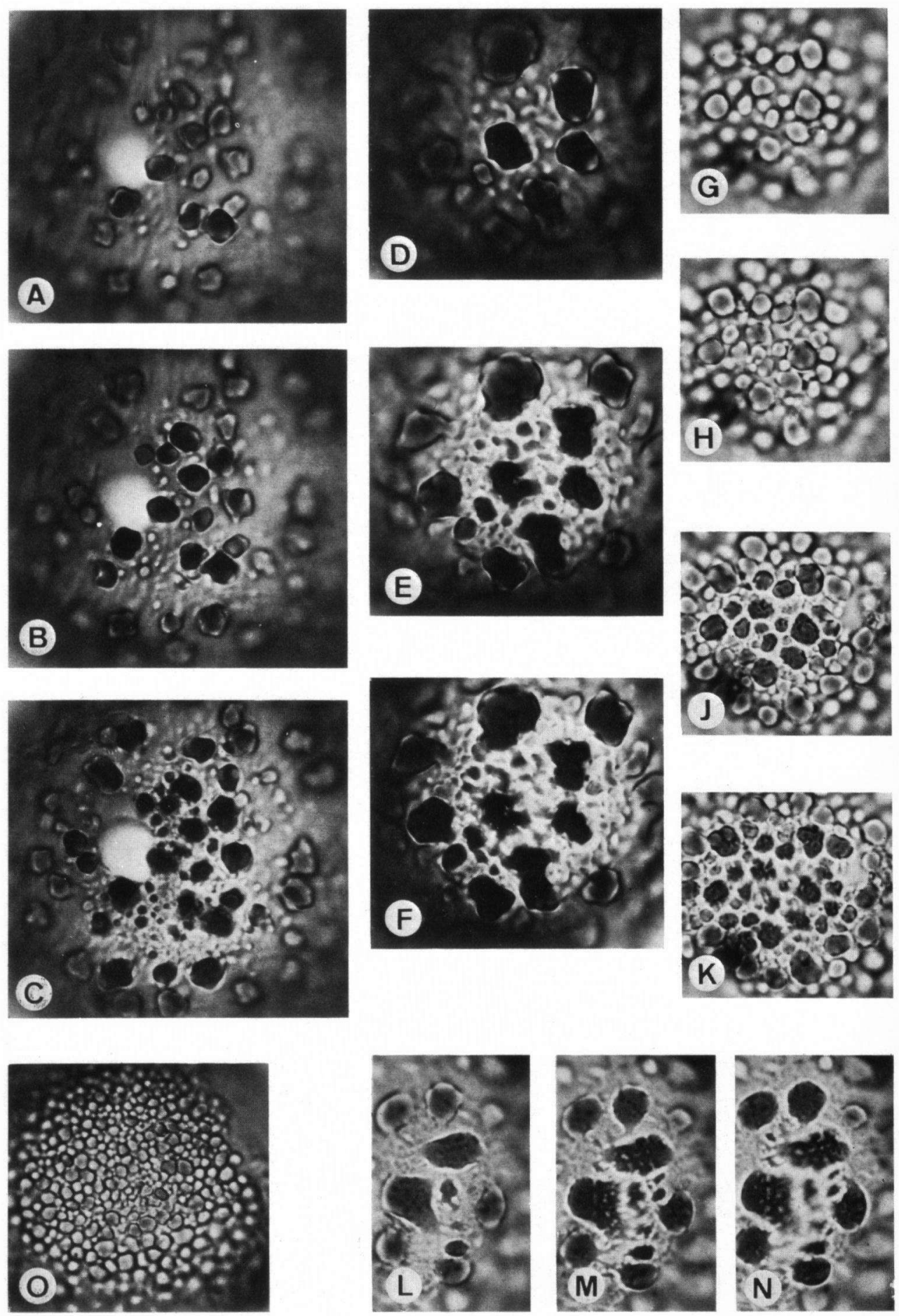


\section{PLATE XXX}
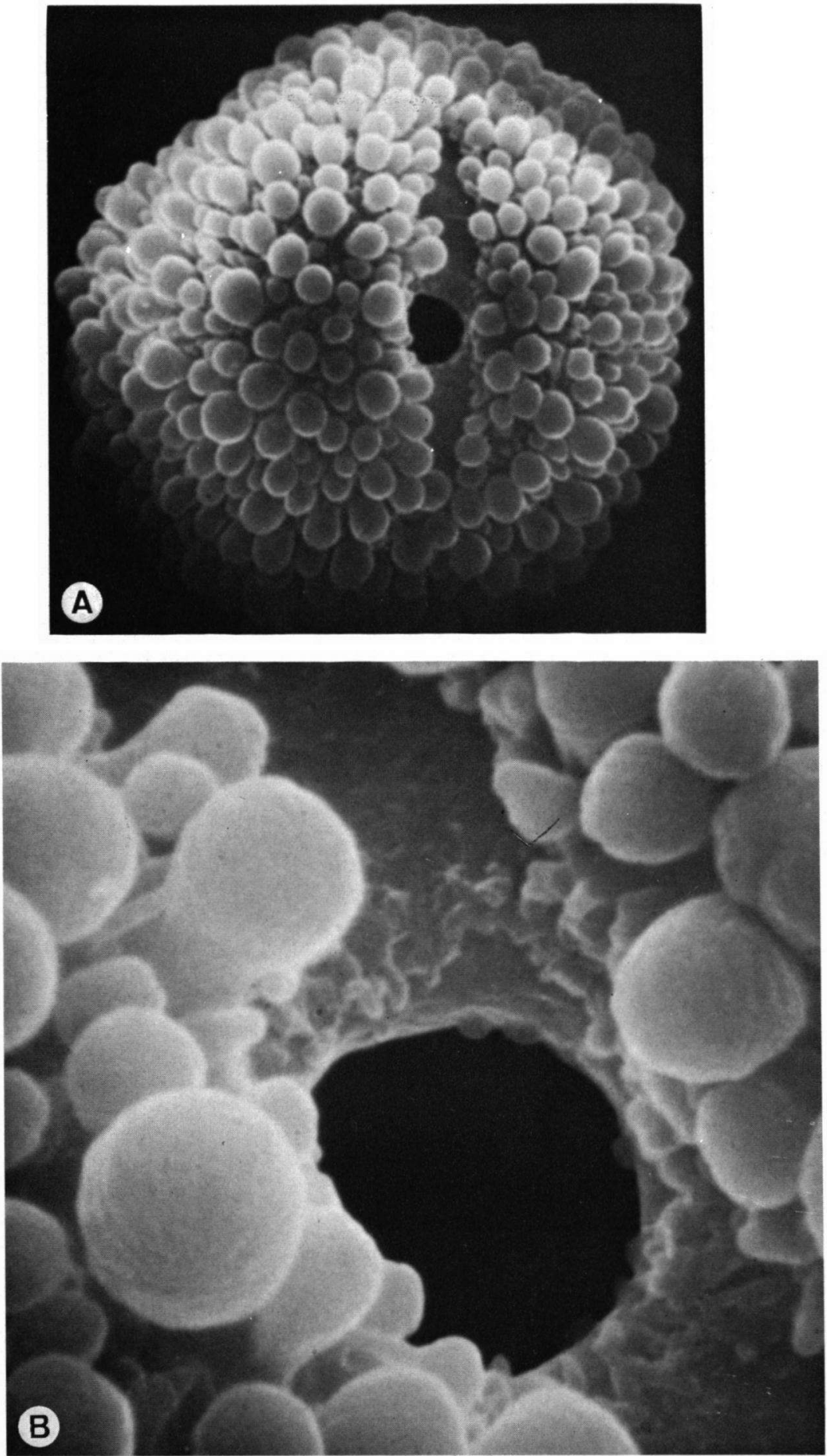

Rev. Palaeobotan. Palynol., 10 (1970) 249-332 
PLATE XXXI
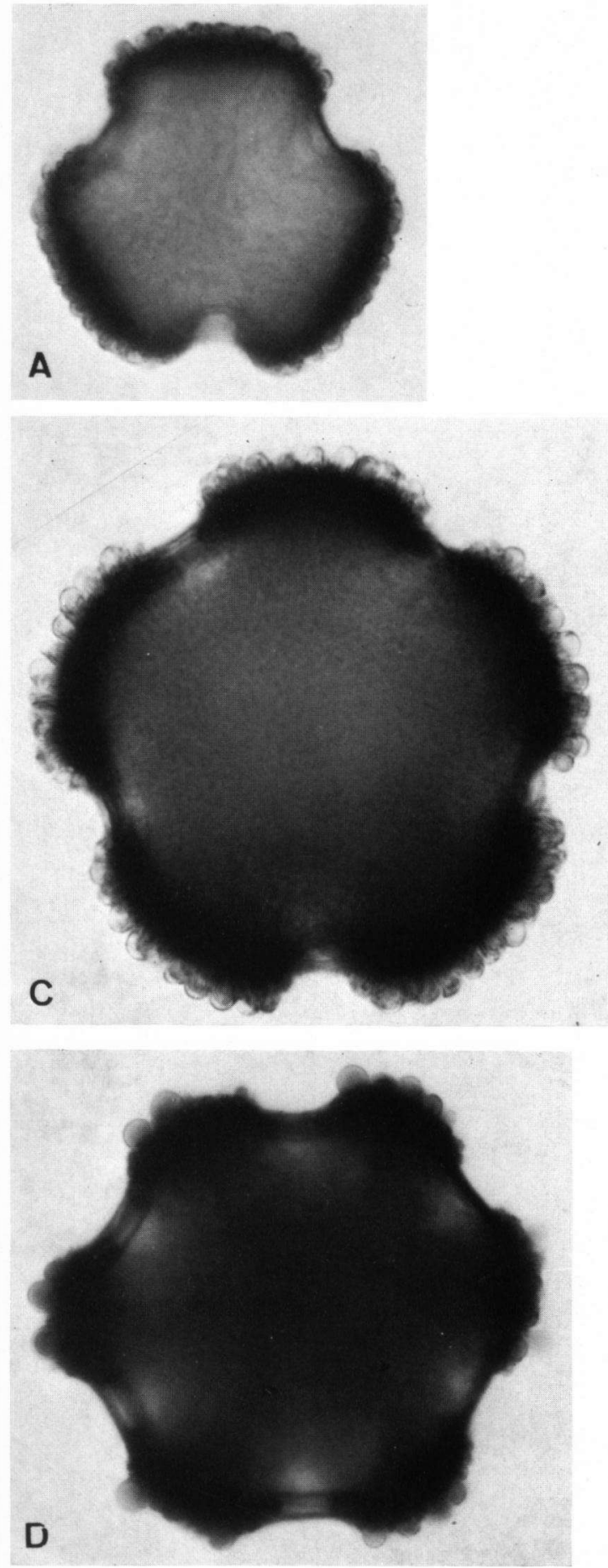
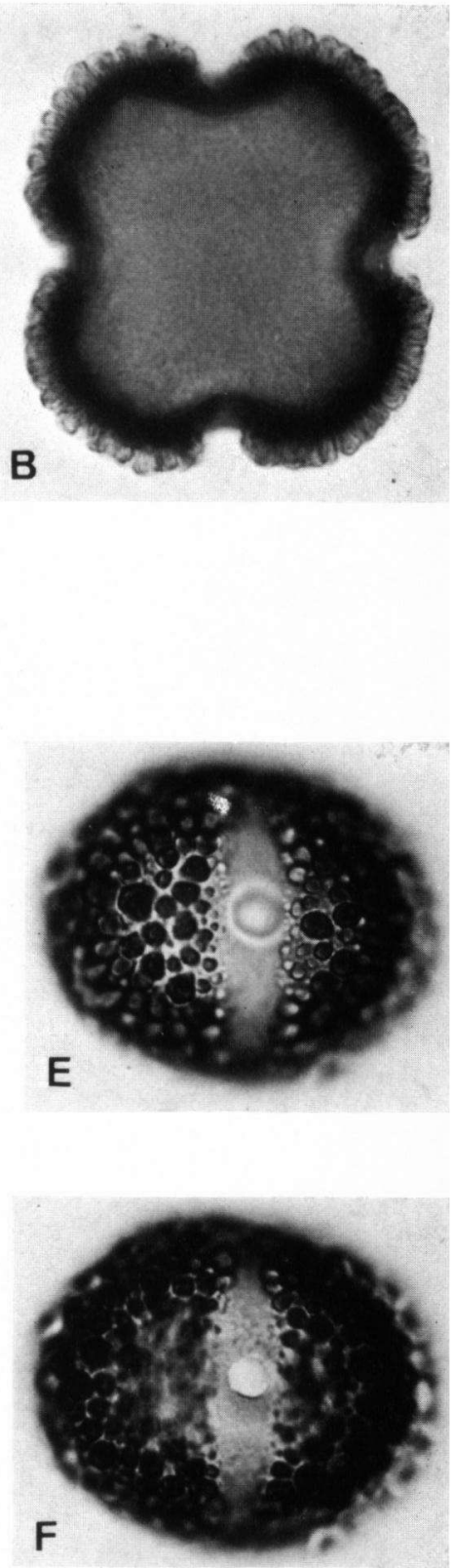
PLATE XXXII
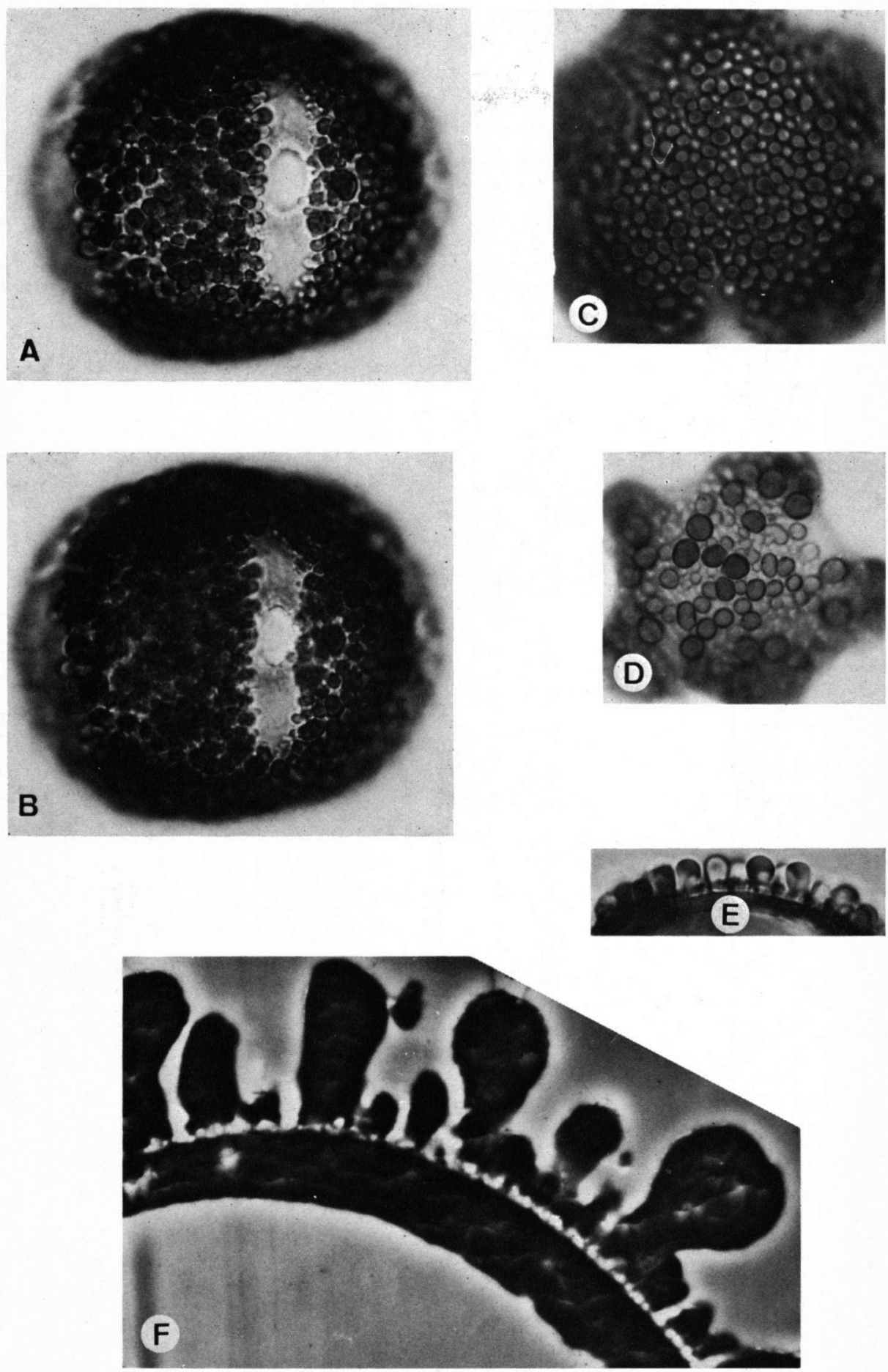

Rev. Palaeobotan. Palynol., 10 (1970) 249-332 


\section{PLATE XXXIII}
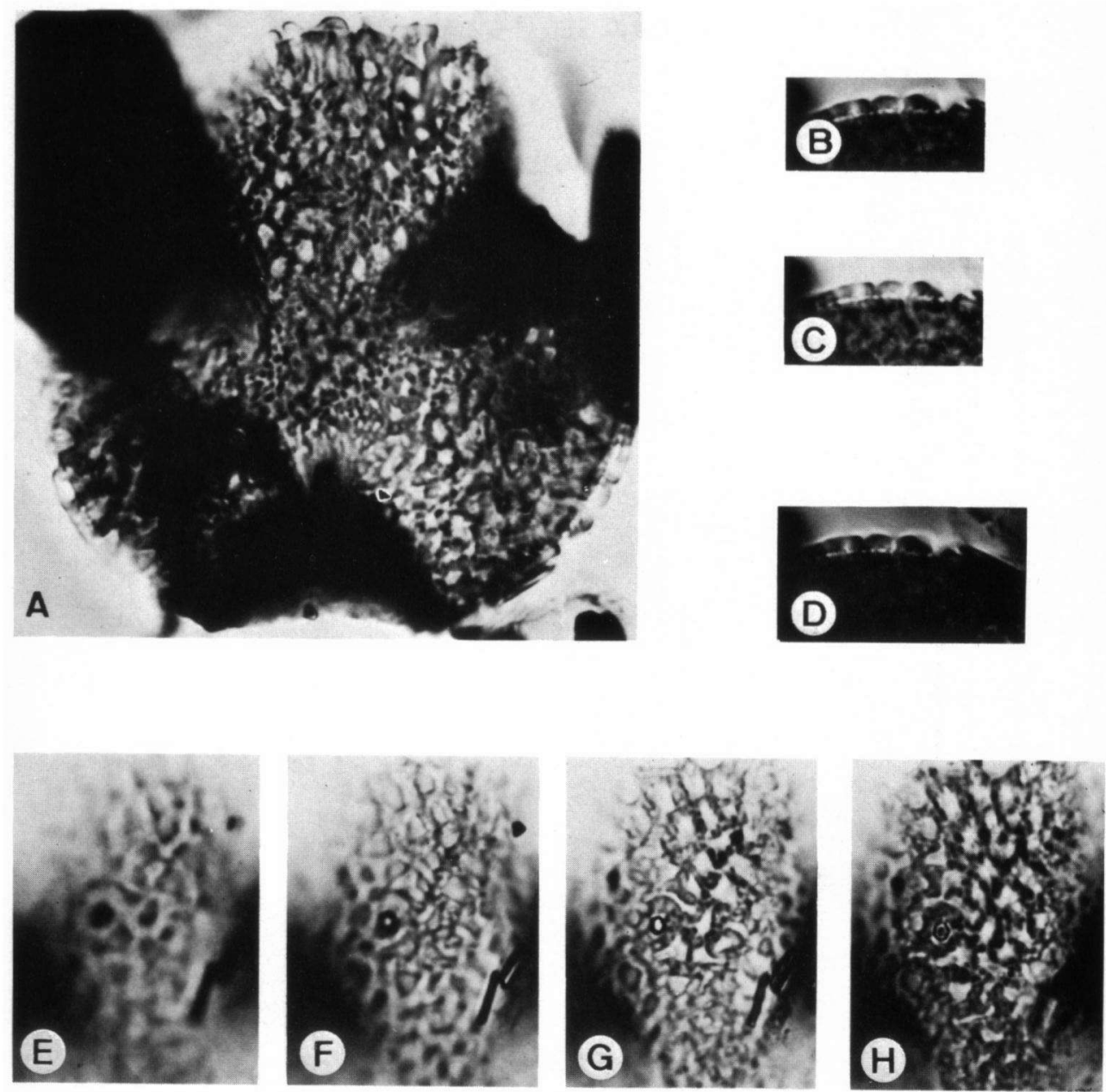